DANMARKS GEOLOGISKE UNDERSØGELSE

11. Række. Nr. 108

Geological Survey of Denmark. II. Series, No. 108

\title{
The Soby Flora: Fossil plants from the Middle Miocene delta deposits of the Søby-Fasterholt area, Central Jutland, Denmark. Part II.
}

\author{
BY \\ Erik Fjeldsø Christensen \\ DANSK SAMMENDRAG
}

Soby Floraen: Fossile planter fra de mellem miocane delta aflejringer i Søby-Fasterholt omiaidet, Midtjylland, Danmark

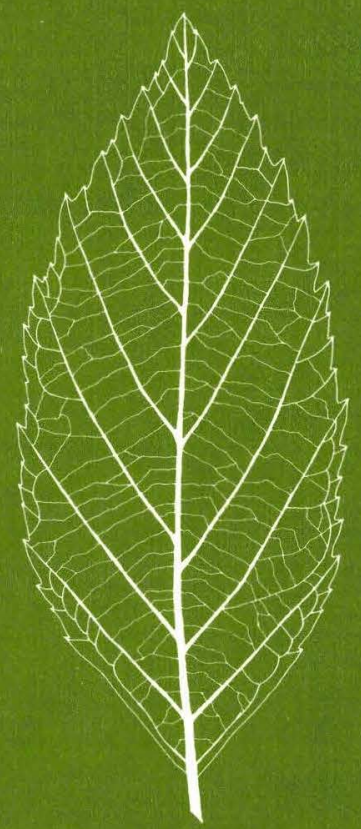

I kommission hos C. A. Reitzels Forlag . København 1976 
Danmarks Geologiske Undersøgelse . II. Række. Nr. 108

Geological Survey of Denmark . II. Series. No. 108

\section{The Søby Flora: Fossil plants from the Middle Miocene delta deposits of the Søby-Fasterholt area, Central Jutland, Denmark. Part II.}

By

Erik Fjeldsø Christensen

Dansk sammendrag:

Søby Floraen: Fossile planter fra de mellem miocæne delta aflejringer i Søby-Fasterholt området, Midtjylland, Danmark

I kommission hos C. A. Reitzels Forlag

København 1976 
D.G.U. II. rk. nr. 108

er sat med Linotype Times

og trykt i offset i 1650 eksemplarer

hos Andelsbogtrykkeriet i Odense.

Bogen er trykt på Thai-Cote, $115 \mathrm{~g}$

fra a/s De forenede Papirfabrikker.

ISBN 87-421-0701-6

With 12 plates

Date of publication: 1976-09-17

The author's address:

Department of Phytopalaeontology

Geological Institute

University of Aarhus

Universitetsparken

DK-8000 Aarhus C

Denmark

Vignetten på omslaget er tegnet af Joan Lützhöft. 


\section{Contents}

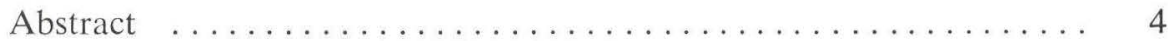

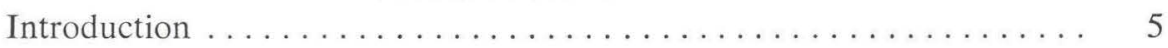

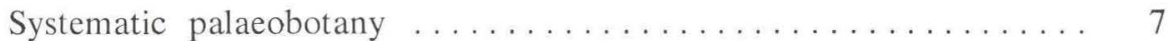

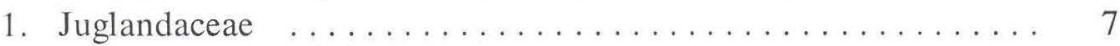

Juglans acuminata ....................... 7

Juglans juglandiformis .................... 13

2. Betulaceae ............................ 15

Alnus julianaeformis ....................... 15

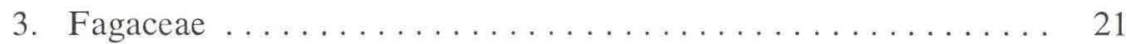

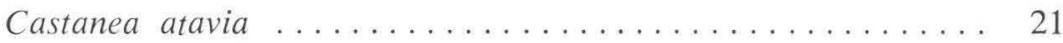

4. Hamaelidaceae ........................... 26

Liquidambar europaea ........................ 26

5. Ulmaceae ............................ 33

Ulmus pyramidalis ....................... 33

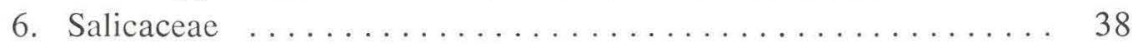

Salix lavateri ......................... 38

Acknowledgements ......................... 44

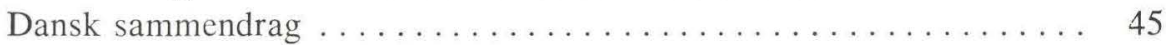

References ................................ 47

Plates ................................. 51 


\section{Abstract}

The taxonomical treatment of the Søby Flora is continued in this work. The present paper is the second of 3 publications in which the flora will be described and the environmental and climatic conditions interpreted. A detailed description of leaf architecture and cuticular anatomy is given on the following species: Juglans acuminata Braun, Juglans juglandiformis (Sternb.) Giebel (no cuticle preserved), Alnus julianaeformis (Sternb.) Kvaček et Holý, Castanea atavia Unger, Liquidambar europaea A. Braun, Ulmus pyramidalis Goeppert and Salix lavateri A. Braun sensu Hantke 1954. 


\section{Introduction}

In 1969 a new fossil flora was found in a clay bed at the top of the Odderup Formation in the Søby-Fasterholt area. A description of the plant locality has previously been given by the author (Christensen 1975, pp. 7-13). This paper also contained the first part of the taxonomical treatment of the Søby Flora where the following genera and species were described: Pinus thomasiana (Goepp.) Reichenbach, Taxodium dubium (Sternb.) Heer, Smilax weberi Wessel and Comptonia acutiloba Brongniart.

The present paper is the second of 3 publications in which the Søby Flora is planned to be described. Hence this paper is descriptive and concentrates on the taxonomy of the fossil plants. This description of the fossil plants community, together with the geological observations, may create the basis for interpretation of the environmental and climatic conditions shortly before the Søby-Fasterholt area was transgressed by the sea (Hodde Formation).

In the present paper the author has modified his way of describing fossil leaf remains, and an attempt is made to bring the terminology in accordance with the descriptive terms given by Dilcher (1974) in his illustrated dictionary. 


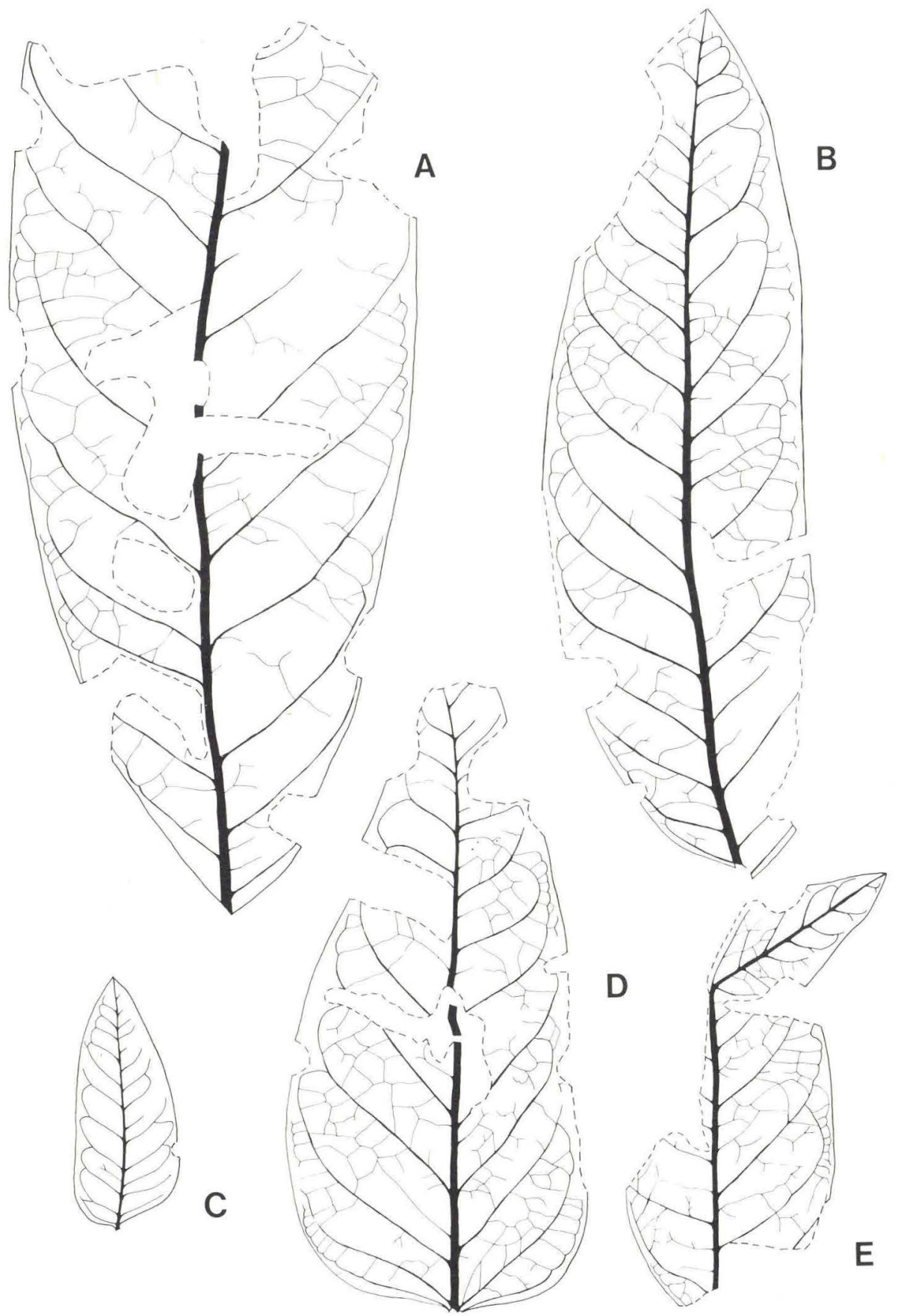

Fig. 1. Juglans acuminata Braun. A-E: Leaves (leaflets) showing variation in morphology, $\times 1$. 


\section{Systematic palaeobotany}

Family Juglandaceae

Genus Juglans L.

Juglans acuminata Braun

(Pl. 1, figs. 1-6; pl. 2, figs. 2, 4-6; text-fig. 1, A-E; text-figs. 2 and 3).

1845: Juglans (Carya?) acuminata Braun - Braun, p. 170.

1845: Juglans latifolia Braun - Braun, p. 170.

1850: Juglans acuminata Braun - Unger, p. 468.

1854: Juglans latifolia Braun - Unger, p. 25, pl. 6, fig. 2.

1855: Juglans pallida Goepp. - Goeppert, p. 36, pl. 25, fig. 3.

1855: Juglans seiboldiana Goepp. - Goeppert, p. 36, pl. 25, fig. 2.

1859: Juglans vetusta Heer - Heer, p. 90, pl. 127, figs. 40-44.

1906: Juglans acuminata Braun - Menzel, p. 26, pl. 2, fig. 5.

1919: Juglans acuminata Braun - Kräusel, p. 161, pl. 25, figs. 2, 6.

Material: 67 more or less fragmentary leaflets (compressions) have been collected. Only 6 of these are complete.

\section{Description}

The leaflet. Pl. 1, figs. 1-6; text-fig. 1, A-E). The lamina is symmetrical, normally with an asymmetrical base. The form of the lamina is narrow elliptic or lanceolate. The smallest complete leaflet is $3.8 \mathrm{~cm}$ long, the largest is $11.5 \mathrm{~cm}$ long, but fragmentary material indicates a length up to $18 \mathrm{~cm}$ or more. The width is 1.9 to $5.4 \mathrm{~cm}$. The apex of the leaflet is acute or acuminate. The development of the bases is highly variable. They may be symmetrical, but normally they are asymmetrical with a variable degree of asymmetry. The bases appear acute, obtuse or even rounded. The margin of the leaflet is entire, and the leaflets are shortly petiolate. The venation is camptodromous. The midvein is stout, curved or straight, and gently tapering along length. The secondary veins are alternate or opposite, arising from the midvein at an angle of 45 to $70^{\circ}$. There is only smaller variation in the angle of divergence from base to apex. The secondary veins are curved abruptly, and the loop-forming branches are enclosed by tertiary vein arches. The intersecondary veins are composite. The tertiary veins 
arise at an acute or right angle from the exmedial (lower) side of the secondary veins and at an acute or right angle from the admedial (upper) side. The tertiary veins that arise on the admedial side of the secondaries and curve to join the midvein are forming an acute or right angle with the midvein. The pattern of the tertiary veins is percurrent, the veins are forked and they are oblique to the midvein. The tertiary veins are predominantly alternate and there are 3 to 6 veins per $\mathrm{cm}$ secondary vein. The marginal ultimate venation is looped. The areoles are well developed and the arrangement is random. The shape of the areoles is pentagonal or irregular and they are small. The veinlets are simple and curved or branched.

Epidermis. (P1. 2, figs. 2, 4-6; text-figs. 2, 3). The upper epidermis has a thin cuticle and is composed of 190 to 250 cells per $0.1 \mathrm{~mm}^{2}$. The shape of the cells is isodiametric or slightly elongate and they are 18 to 38 microns long. The arrangement of the cells is pentagonal and the anticlinal cell wall pattern is straight or rounded. The cell walls are 2 to 3 microns thick. The cells over the veins are elongate and they have square or oblique end walls. Surface ornamentation is absent. Trichome bases are present in the upper epidermis. They occur singly and are mainly confined to venation. The bases are widely spaced and there are about 10 to 20 per $1.0 \mathrm{~mm}^{2}$.

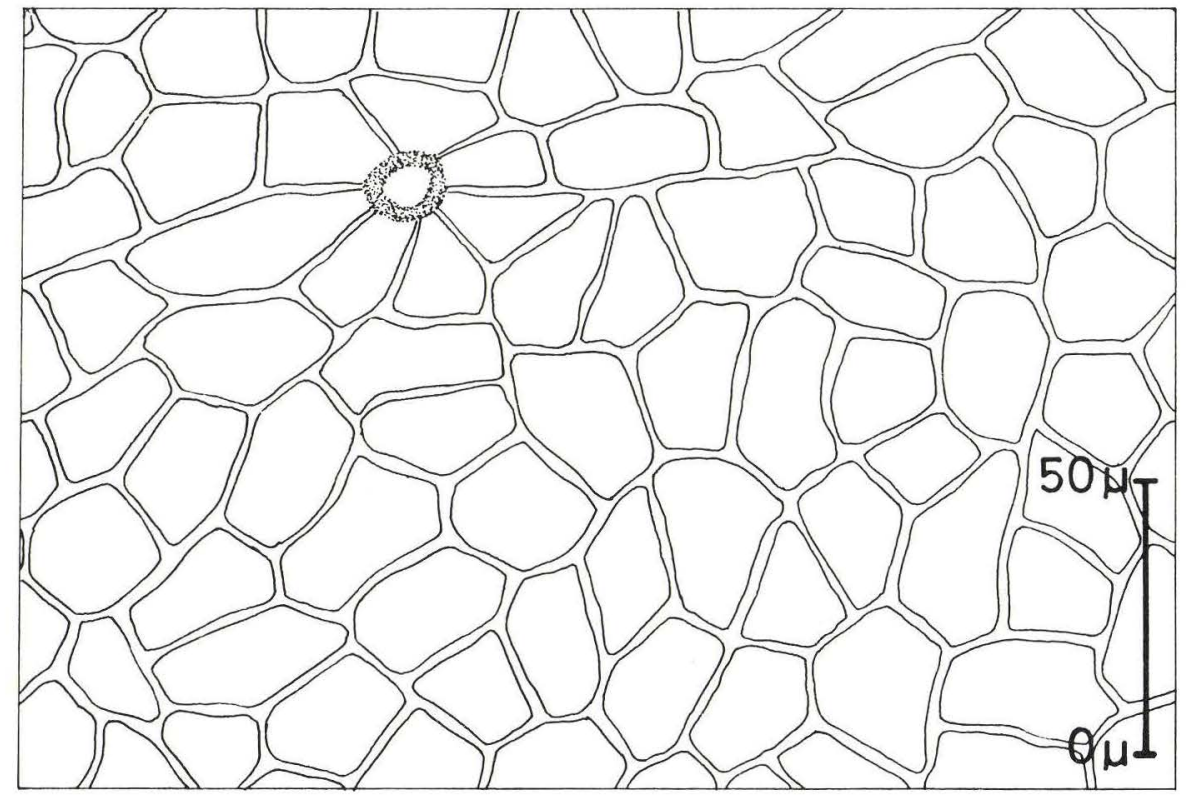

Fig. 2. Juglans acuminata Braun. Upper epidermis with trichome base. 
The trichome bases are strongly thickened and the diameter is 20 to 24 microns. The base is surrounded by a radial arrangement of 7 to 9 associated cells. There has been no observation of attached hairs.

A well developed palisade is found below the upper epidermis. The cell diameter is 8 to 15 microns and there are 700 to 900 cells per $0.1 \mathrm{~mm}^{2}$.

The lower epidermis has a thin cuticle and is composed of approx. 300 to 400 cells per $0.1 \mathrm{~mm}^{2}$. The shape of the cells is isodiametric or slightly elongate, and they are 14 to 30 microns long. The arrangement of the cells is random with 3-, 4-, and 5-sided cells and the anticlinial cell wall pattern is rounded or undulate. The undulation is U-shaped and there are 0 to 7 lobes per cell. The wave length is 8 to 16 microns and the wave amplitude is up to 6 microns. The cell walls are 0.5 to 1.0 micron thick and they have no special ornamentation. The cells over the veins are linear elongate and the end walls are square or oblique. The anticlinal cell wall pattern is straight and the lenght/width ratio is $1 / 1$ to $5 / 1$. The finest veins are not reflected in the cuticle. Surface ornamentation is absent. The stomata (badly disclosed in the Søby material) are variously orientated, slightly sunken and more or less equidistant. There are approx. 30 to 40 stomata per $0.1 \mathrm{~mm}^{2}$ (only few valid measurements) and their length is 16 to 20 microns. The

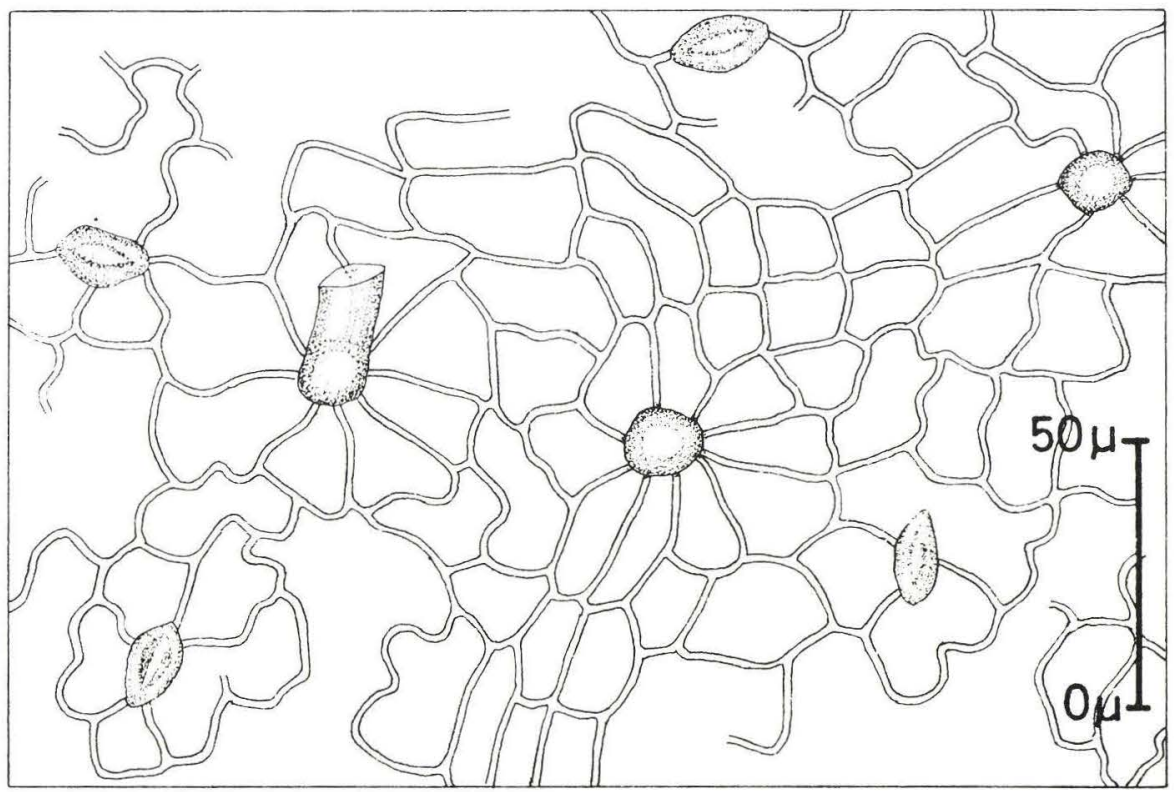

Fig. 3. Juglans acuminata Braun. Lower epidermis with stomata and trichome bases. A broken hair is attached to one of the bases. As shown on the figure the cuticle is only presserved over and near the veins. 
accessory cells are poorly differentiated, they are similar in size to the rest of the epidermis cells and there are 4 to 6 (7?) in number. Further details in the stomatal complex is not known. Trichome bases are present in the lower epidermis. They occur singly and they are found both over veins and in areoles. The bases are strongly thickened, the diameter is 18 to 20 microns and there are approx. 50 to 100 bases per $1.0 \mathrm{~mm}^{2}$. A radial arrangement of 7 to 11 associated cells surrounds the bases. Fragments of hairs are sometimes found attached to the bases. These fragments are funnelshaped, sometimes with transversal cell walls and they are all broken 15 to 20 microns above the base. The further nature of these hairs is not disclosed in the fossil material.

\section{Discussion}

The Søby material examined is charaterized by an entire margin, the same type of venation and by appearing with the same texture and colour after the collodium-film treatment (Christensen 1975, p. 14). The colour is pale amber, and it differs from all other leaves in the flora. However, the shape and size of the leaves is highly variable. A broad variation is found in the leaf bases, and both symmetrical and asymmetrical specimens occur. By careful comparison with descriptions and figures of fossils from other Tertiary floras it becomes probable that the leaves should be considered as leaflets from the composite leaf of Juglans acuminata Braun. But as pointed out by Walther $(1964$, p. 31) the descriptions given on $J$. acuminata is by no means unambiguous. Identification of leaves with entire margins is often very difficult, owing to their lack of sufficient morphological characteristics. Besides, no fruits (nuts) of Juglans or leaflets attached to the rachis have been found in the Søby Flora. Thus a careful examination of the cuticle was undertaken to clear up the problem on the generic affinity of the described leaves (leaflets). The preparation of the cuticle was very difficult, but even though some details are insufficiently illuminated, enough evidence was obtained to establish that the Søby leaflets belong to the genus Juglans. The identification of the fossil species is here based exclusively on morphological characteristics as - to the author's knowledge - no description of the cuticle of Juglans acuminata Braun has previously been given.

\section{Comparison with recent material}

Juglans acuminata is normally compared with the recent Juglans regia. The similarity between the leaf morphology of the two species is evident. But as pointed out by Bužek (1971, p. 44) the leaflets of J. acuminata from North 
Bohemia are more slender than the leaflets of J. regia. This is also the case with the Søby material.

The tertiary veins in $J$. regia normally have a right angle of origin from the secondary veins, while the angle of origin more frequently appears acute in $J$. acuminata. Unbranched tertiary veins are often found in $J$. regia. In $J$. acuminata they are normally branched and the smallest areoles are found in the fossil material.

A comparison of the cuticle of the two species is only possible to a certain extent, as the cuticle of the fossil species is rather badly preserved.

The cells in the upper epidermis of J. regia are of the same shape and have the same arrangement as found in $J$. acuminata, but the cells are generally a little larger. The cell walls are undulate in the recent species and rarely straight as in $J$. acuminata. The nature of the trichome bases and the associated cells has the same occurrence in the upper epidermis of the two species, but the hairs are unknown in J. acuminata.

A well developed palisade is found below the upper epidermis of both species, and the cells are of the same dimensions.

The cells in the lower epidermis of the two species have the same shape, arrangement, size and type of undulation in the cell walls. The nature and occurrence of the trichome bases is also the same. The stomata is slightly sunken in both species, and they have the same type of stomatal complex. Further comparison of the stomata is difficult because of insufficient data on the fossil material. The lenght of the stomata is generally smaller in J. acuminata (the width is not well defined and therefore not measured). But it must be taken into consideration that the stomata of $J$. regia roughly fall in two size groups, the large ones, about 35 microns long and the small ones, about 25 microns long, and the length of the smallest reaches the stomatal length in $J$. acuminata. Further, the number of accessory cells around the small stomata of $J$. regia is the same as in $J$. acuminata, while the number around the large stomata may even reach 11 .

Only fragments of hairs have been found attached to the trichome bases of the lower epidermis of $J$. acuminata. Some of these hair fragments contain more than one cell and they might represent the broken stalked capitate glands found in all species of Juglans.

Juglans acuminata from the Søby Flora shows a broad and solid similarity to Juglans regia, which justifies the relationship to the genus Juglans. The differences pointed out here are clear enough to show that we are dealing with two distinct species. 


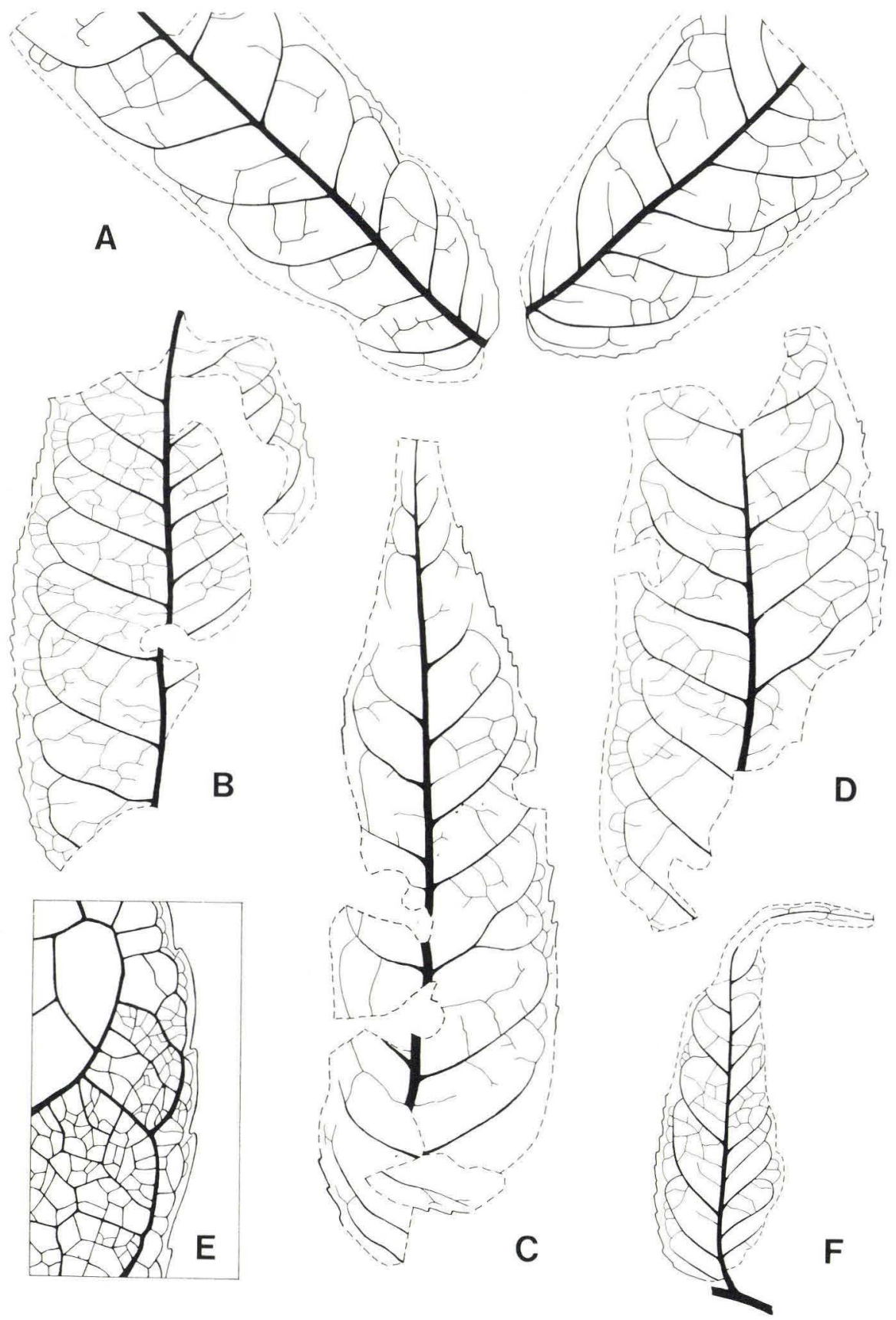

Fig. 4. Juglans juglandiformis (Sternb.) Giebel. A: Two leaflets in original position, $\times 1$. B-D: Leaflets showing venation, $\times 1$. E: Detail of venation and leaf margin. F: Leaflet from the basal part of the leaf attached to a fragment of the rachis, $\times 1$. 
Juglans juglandiformis (Sternb.) Giebel

(Pl. 3, figs. 1-8, text-fig. 4, A-F).

1825: Phyllites (Fraxnus) juglandiformis Sternb. - Sternberg, p. 37, pl. 35, fig. 1.

1849: Juglans bilinica Unger - Unger, p. 126, pl. 14, fig. 20.

1850: Juglans bilinica Unger - Unger, p. 469.

1852: Juglans juglandiformis (Sternb.) Giebel - Giebel, p. 149.

1861: Carya bilinica (Unger) Ettingshausen - Unger, p. 39, pl. 17, figs. 1-8.

1869: Carya bilinica (Unger) Ettingshausen - Ettingshausen, p. 46, pl. 51, figs. 6, $13-15$, pl. 52 , figs. $4,7-11$.

1885: Juglans bilinica Unger - Engelhardt, p. 361, pl. 16, figs. 23, 28, 29, pl. 17, figs. $1-3,6,7$.

Material: 96 more or less fragmentary leaflets (compressions) have been collected. Only 6 of these are complete.

\section{Description}

The leaflet. (Pl. 3, figs. 1-8; text-fig. 4, A-F). The lamina is symmetrical and the base is asymmetrical or occasionally symmetrical. The form of the lamina is narrow oblong, lanceolate or elliptic. The smallest complete leaflet is $6.5 \mathrm{~cm}$ long and the largest is $13.2 \mathrm{~cm}$. The width is 1.6 to $4.6 \mathrm{~cm}$ in the middle part of lamina. The apex of the leaflet is acute or attenuate. The base is normally markedly asymmetrical, as the margin arises at an obtuse angle to the midvein on one side and at an acute angle on the other side of the leaflet. In a few leaflets the base is symmetrical and appears to be normally acute. The margin of the leaflet is toothed. It is serrate as the axes of the teeth are inclined to the tangent of the margin. The apical angle is acute or obtuse. The apical side of the tooth is straight or convex and the basal side is always convex. The sinuses between the serrations are angular and there are irregular intervals between the simple teeth. The teeth are extended on the complete margin. There are 14 to 20 teeth per $5 \mathrm{~cm}$ margin and the teeth are 0.3 to $0.8 \mathrm{~mm}$ across. The leaflets with asymmmetrical base are shortly petiolate, while the leaflets with symmetrical base may have a very long extension of the midvein. The venation is camptodromous. The medvein is stout, curved or straight and gently tapering along length. The secondary veins are alternate or opposite, and they arise from the midvein at an angle of 55 to $75^{\circ}$. There is no regular variation in the angle of divergence from base to apex. The secondary veins are abruptly curved, and the loop-forming branches are enclosed by tertiary vein arches. The intersecondary veins are composite. The tertiary veins arise at an acute angle from both the exmedial (lower) and the admedial (upper) side of the secondary veins. The tertiary veins that arise on the admedial side of the secondaries and curve to join 
the midvein form an acute angle to the midvein. The pattern of the tertiary veins is percurrent, the veins are forked and they are oblique to the midvein. The tertiary veins are predominantly alternate and there are 4 to 6 veins per $\mathrm{cm}$ secondary vein. The marginal ultimate venation is looped. The areoles are well developed and the arrangement is random. The shape of the areoles is quadrangular or pentagonal, and they are small to medium in size. The veinlets are simple or branched.

Epidermis. The cuticle of the epidermis is very badly preserved. In a few cases shades of cells with straight walls, that probably belong to the upper epidermis, have been observed, but no details at all have been disclosed by the Søby material.

\section{Discussion}

The material examined seems to represent leaflets of a compound leaf. The leaflets are occasionally found in the sediment in a position corresponding to the arrangement of the leaflets of a compound leaf. In a few cases a leaflet is attached to a fragment of what is believed to be the rachis of the leaf. The presence of a few leaflets with a symmetrical base indicates the same thing as they probably represent terminal leaflets.

The leaflets decribed here are normally known from the literature as Juglans bilinica Unger or more correctly as Juglans juglandiformis (Sternb.) Giebel; LaMotte (1944, p. 178). The determination of the Søby fossils is exclusively based on morphological identity with the described fossils and on a general resemblance to the recent leaves of the genus Juglans. But as the cuticle is extremely badly preserved it has not been possible to confirm the generic relationship. It is normally agreed that leaflets of the described type belong to the family Juglandaceae, but different generic names have been assigned to them. Unger (1861) uses the name Carya bilinica for these fossils, and as pointed out by Bůžek (1971) they have a certain resemblance both to the genus Juglans and to the genus Carya.

Knobloch (1969) describes similar leaves as Pterocarya paradisiaca (Unger) Iljinskaja, and he includes the original specimen of Juglans bilinica in the list of synonyms. In his discussion Knobloch $(1969$, p. 68) points out that no problem exists in separating leaflets of Pterocarya from leaflets of Cyclocarya. This has been pointed out by Mai (1963, p. 50). Later Knobloch draws attention to the morphological differences between the leaflets of Pterocarya and Carya, but no comments are made on how to separate leaflets of Pterocarya from serrate leaflets of Juglans. Walther (1964) claims that a determination of the leaflet of the different genera should be possible if 
venation, margin, base and apex of the leaflets are well preserved. The characteristics of the genera are summarized in his fig. 3, p. 29, but unfortunately leaflets of Pterocarya are compared only to entire-margined leaflets of Juglans.

The fossil leaflets from S $\phi$ by seem to bear the largest resemblance to the genus Juglans. However, this indication has not been supported by evidence from the cuticle or from the presence in the $\$ \varnothing b y$ deposit of any fruits of the Juglandaceae. Until further evidence is provided it cannot be considered as proved that the Søby fossils belong to the genus Juglans and not to the genus Pterocarya.

Fruits of Pterocarya have previously been reported in a large number from the sligthly older Fasterholt Flora of the same area (Koch et al. 1973). Until now these are the only fruits of the Juglandaceae found in this flora, but this might only reflect the different environments.

Family Betulaceae

Genus Alnus B. Ehrh.

Alnus julianaeformis (Sternb.) Kvaček et Holý

(P1. 4, figs. 1-10; pl. 5, figs. 2, 4-6; text-fig. 5, A-I; text-figs. 6, 7).

1823: Phyllites julianaeformis Sternb. - Sternberg, p. 37, pl. 36, fig. 2.

1847: Fagus feroniae Ung. - Unger, p. 106, pl. 28, figs. 3, 4.

1866: Fagus feroniae Ung. - Ettingshausen, p. 126, pl. 15, figs. 12-22, pl. 16, fig. 1.

1934: Alnus feroniae (Ung.) Czeczott - Czeczott, pp. 109-116, text-figs. 29, 30.

1954: Alnus attenuata Geopp. - Kräusel et Weyland, p. 132, pl. 28, figs. 5, 6, pl. 29, figs. 1,2 , text-figs. 1,13 .

1971: Alnus feroniae (Ung.) Czeczott - Kilpper, pp. 349-352, text-figs. 1-3.

1974: Alnus julianaeformis (Sternb.) Kvaček et Holý - Kvaček et Holý, pp. 367-372, pl. 1 , figs. $1-7$, pl. 2 , figs. $1-7$, pl. 3 , figs. $1-6$, pl. 4 , fig. 1 , text-fig. 1 .

1975: Fagus feroniae Ung. - Mathiesen, p. 14, text-fig. 9, A-E.

Material: 115 more or less fragmentary leaves (compressions) have been collected. 19 of these are complete. 6 female catkins have been found associated with the leaves.

\section{Description}

The leaf. (P1. 4, figs. 1-8; text-fig. 5, A-I). The lamina is symmetrical and it normally has a symmetrical base. The form of the lamina is elliptic or narrow ovate (lenght/width ratio approx. 2/1). The smallest complete leaf is $4.2 \mathrm{~cm}$ long and $2.0 \mathrm{~cm}$ wide, while the largest is $7.6 \mathrm{~cm}$ long and $3.9 \mathrm{~cm}$ 

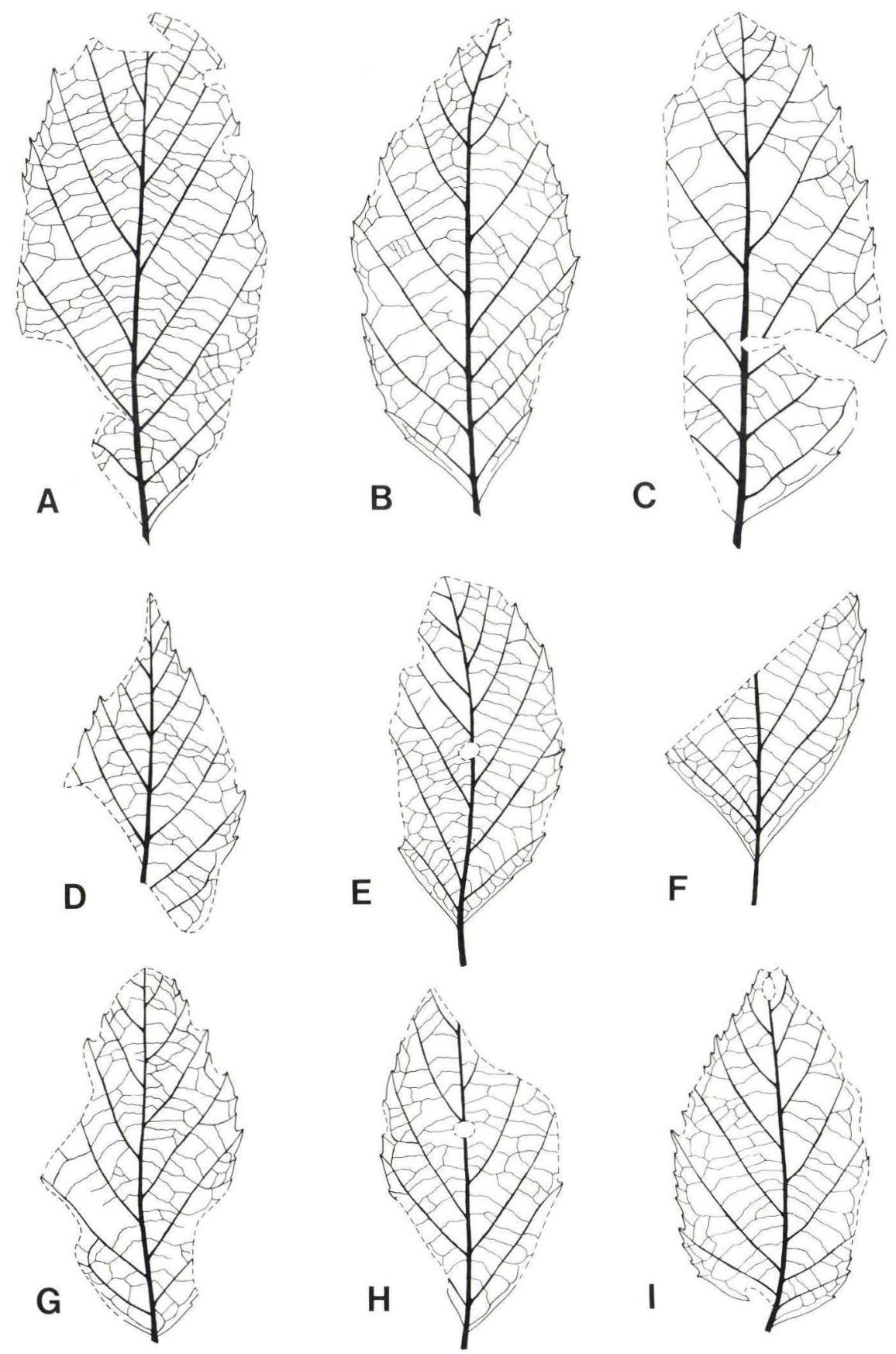

Fig. 5. Alnus julianaeformis (Sternb.) Kvaček et Holý. A-I: Leaves showing morphology and venation, $\times 1$. 
wide. The leaf apex is acute or acuminate. The leaf base is somewhat variable. It varies from decurrent acute to normal obtuse, but the most common type is cuneate acute or obtuse. The leaf margin is toothed. It is serrate as the axes are inclined to the tangent of the margin. The teeth fall into two size groups. The larger, served by the secondary veins, have an acute apical angle. The apical side of the tooth is straight or concave and the basal side is acuminate. There are 1 to 3 smaller teeth per intercostal field and they are of the same type as the larger teeth. The sinuses between the serrations are angular. The teeth are extended on the whole margin. There are 5 to 7 larger teeth per $5.0 \mathrm{~cm}$ margin and they are 0.8 to $1.5 \mathrm{~mm}$ across. The smaller teeth are 0.2 to $0.6 \mathrm{~mm}$ across. The leaves are petiolate. The length of the petiole is up to $1.2 \mathrm{~cm}$ or even more. The venation is simple craspedodromous. The medvein is moderate, straight or curved and gently tapering along length. The secondary veins are opposite or nearly opposite near the base but they become alternate toward the apex. The angle of divergence is 30 to $55^{\circ}$ and the angle gradually decreases from base to apex. The secondary veins are straight or gently curved and run directly into the larger teeth. Branching of the secondaries occasionally occurs. The tertiary veins arise at a right or almost right angle from both the exmedial (lower) and the admedial (upper) side of the secondary veins. The tertiary veins arising on the admedial side of the secondaries curve to form a right or almost right angle to the midvein. The pattern of the tertiary veins is percurrent, the veins are simple or forked and they are oblique to the midvein. The tertiary veins are predominantly alternate and there are 5 to 7 veins per $\mathrm{cm}$ secondary vein. The quarternary veins are orthogonal. The smaller teeth in the leaf margin are served by quarternary veins arising from the tertiary vein running along the leaf margin. The areoles are well developed and the arrangement is orientated. The shape of the areoles is quadrangular or pentagonal. They are small and the veinlets are branched or unbranched.

Epidermis and internal structures. (Pl. 5, figs. 2, 4-6; text-figs. 6, 7). The cuticle of the upper epidermis is thin and it is composed of approx. 500 cells per $0.1 \mathrm{~mm}^{2}$. The shape of the cells is isodiametric or slightly elongate and the lenght is 10 to 18 microns. The arrangement of the cells on the whole is pentagonal and the anticlinal cell wall pattern is rounded or straight. The cell walls are 1.0 to 1.5 microns thick. The cells over the veins are elongate and the cell walls are straight. The finer veins are reflected in the cuticle. The cells in the leaf margin are of the same type as the normal epidermis cells in the non-venous area, but the cell walls are a little thickened. The trichome bases are widely spaced and they are mainly found over the veins. They normal- 
ly consist of 4 strongly cutinized cells and the diameter of the base is 19 to 23 microns.

Occasionally a hypodermis is observed below the upper epidermis. The cells are isodiametric and markedly larger than the cells of the upper epidermis. They are 26 to 38 microns across.

Palisade cells are sometimes preserved in the Søby leaves. They are about 10 microns in diameter.

The cuticle of the lower epidermis is very thin, often badly preserved, and the following description is only based on a few preparations. The epidermis is composed of approx. 450 cells per $0.1 \mathrm{~mm}^{2}$. The shape of the cells is isodiametric and they are 15 to 23 microns long. The arrangement of the cells is pentagonal and the anticlinal cell wall pattern is undulate. The wave length is 7 to 10 microns, the wave amplitude is approx. 3 microns and there are up to 7 lobes per cell. The cell walls are 1.0 to 1.5 microns thick. The cells over the veins are elongate and the cell walls are straight. Trichome bases with 4 strongly cutinized cells are found over the veins. They are identical with those found in the upper epidermis, but they appear more frequently. The stomata are variously orientated, undepressed and more or less equidistant. They are 19 to 24 microns long and 17 to 22 microns wide. The outer stomatal ledges are conspicous and in many cases only

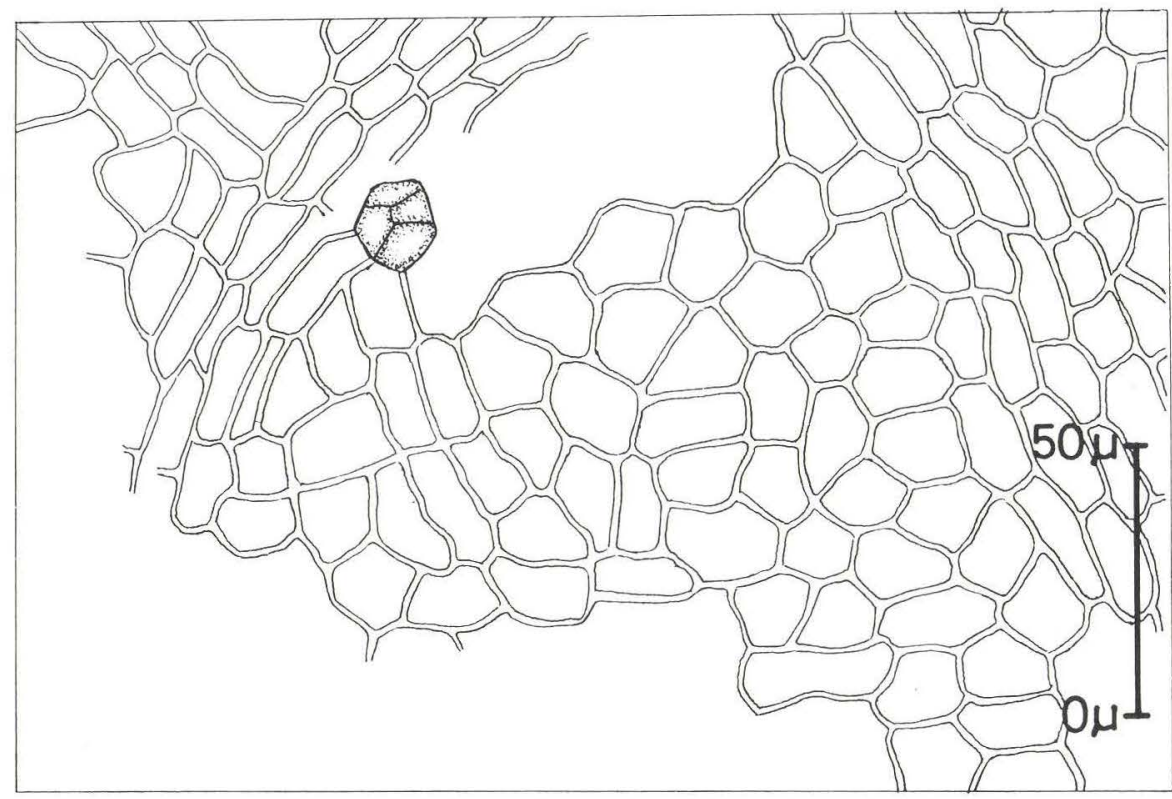

Fig. 6. Alnus julianaeformis (Sternb.) Kvaček et Holý. Upper epidermis with a strongly cutinized 4-celled trichome base over a vein. 
these are preserved. The accessory cells are not differentiated in any way from the normal epidermis cells. A large number of unbranched simple hairs are found in the corners where the secondaries arise from the midvein. They are 70 to 180 microns long and they are approx. 10 microns thick near the base. The hairs are found over the veins (midvein, secondary vein and higher order venation) in this particular area and they leave a simple one celled hair base 10 to 13 microns across.

Female catkins. (Pl. 4, figs. 9, 10). The female catkins are poorly preserved and do not allow detailed examination. The only information to be given here is that the compressed catkins are 1.7 to $2.0 \mathrm{~cm}$ long and 1.3 to 1.6 $\mathrm{cm}$ broad.

\section{Discussion}

Comments on the typication and the systematics of Alnus julianaeformis have recently been given by Kvaček and Holý (1974, pp. 368-369). They put forward that Sternberg's specific name should be used instead of the more commonly used name Alnus feroniae (Ung.) Czeczott. No description is given on the leaf morphology as the reader can find it in the paper of Czeczott

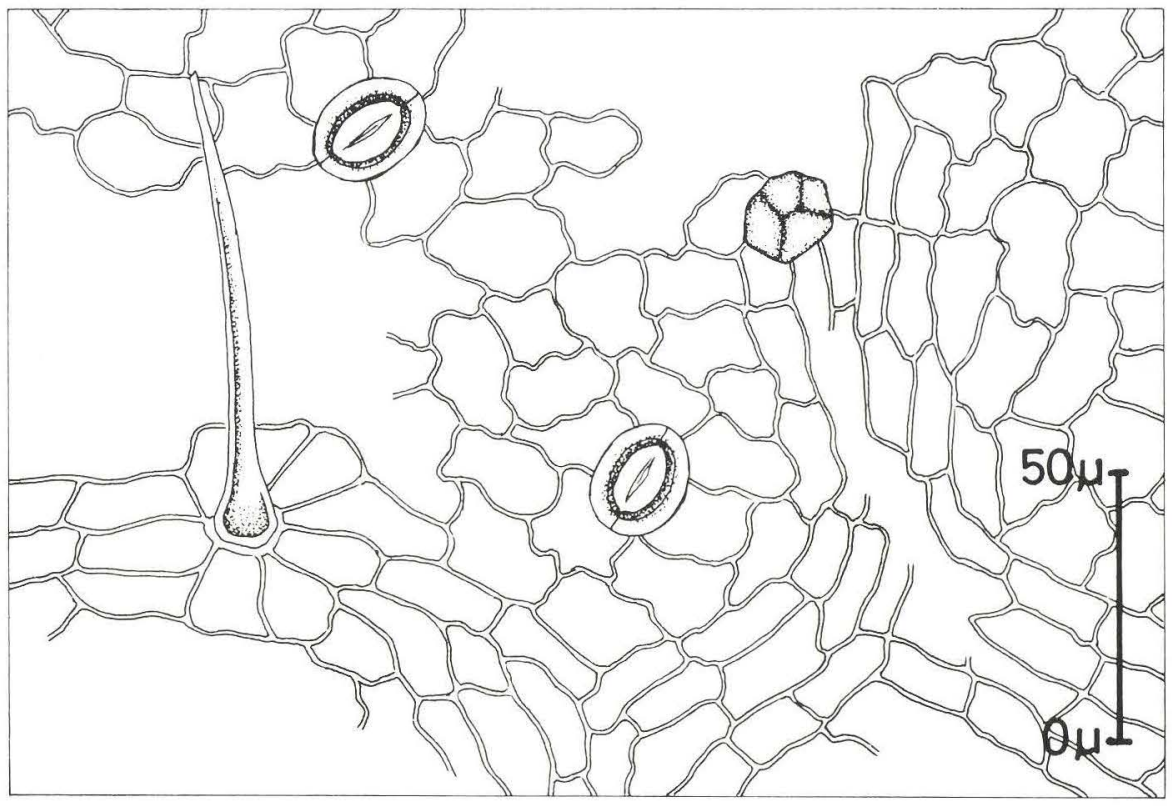

Fig. 7. Alnus julianaeformis (Sternb.) Kvaček et Holý. Lower epidermis with stomata. Over the veins a 4-celled trichome base and a simple hair are seen. 
(1934), but a very well illustrated destription is given on the leaf anatomy (Kvaček et Holý 1974, p. 369, pl. 3, figs. 1-6 and pl. 4, fig. 1).

The morphology of the leaves from the S $\varnothing$ by Flora corresponds fully to the description given by Czeczott (1934) and to the one given by Kilpper (1971, pp. 349-350). Even though the cuticle of the Søby leaves is badly preserved, the characteristics mentioned by Kvaček and Holý are present except the rounded shield of the glands. It is mentioned that simple thinwalled hairs, approx. 120 microns long and 10 microns thick occur densely over the veins in the lower epidermis. Such hairs are found in the lower epidermis of the Søby leaves, but they only occur densely in the corners between the primary and secondary veins.

Alnus julianaeformis has previously been reported from the Neogene Tertiary lignites of Central Jutland by Mathiesen (1975). It is described as Fagus feroniae Unger (Mathiesen 1975, pp. 14-16). Only drawings are presented (fig. 4, A-E). The leaves are identical with $A$. julianaeformis except for the lack of the smaller teeth which are indicated in fig. $4 \mathrm{C}$ only. The absence of the smaller teeth must be due to the state of preservation as the leaves are only preserved as imprints. Alnus female catkins have also been reported from Moselund (Mathiesen 1975, p. 21 and p. 20, fig. 8, A, B). They have not allowed closer study and have not been linked to any of the leaves described.

The knowledge of the female catkins of A. julianaeformis is not improved here as the Søby material is badly preserved and no specific characteristics are revealed. The female catkins are mentioned under $A$. julianaeformis because they are identified as Alnus and because they are found in the same bed as $A$. julianaeformis, which is the only known Alnus species in the Søby Flora.

\section{Comparison with recent material}

It has previously been pointed out that Alnus julianaeformis has a large morphological resemblance to the recent Alnus japonica Sieb. et Zucc. (Czeczott 1934 and Kilpper 1971). The epidermis of the Søby leaves has been compared to the epidermis of Alnus japonica. There seem to be several differences in the epidermis of the two species. The cells and the trichome bases of the upper epidermis are larger in $A$. japonica. In the lower epidermis, the trichome bases and the stomata are larger in the recent species and the cell walls are normally not undulate. The same differences have been pointed out by Kvaček and Holý, and they suggest Alnus trabeculosa Hand.-Mazz. as a possible counterpart to $A$. julianaeformis because of a larger similarity in the cuticle. 
Family Fagaceae

Genus Castanea L.

Castanea atavia Unger

(Pl. 6, figs. 1-5; pl. 7, figs. 2, 4, 6; text-fig. 8, A-E; text-figs. 9, 10).

1851: Castanea atavia Ung. - Unger, p. 164, pl. 10 (31), figs. 5, 7.

1872: Castanea atavia Ung. - Ettingshausen, p. 153.

1888: Castanea atavia Ung. - Ettingshausen, p. 292.

1906: Castanea atavia Ung. - Menzel, p. 58, pl. 3, figs. 14, 15, 19, pl. 4, figs. 1-4, 8 .

1919: Castanea atavia Ung. - Reichenbach in Kräusel, p. 130, pl. 11, figs. 6-8, pl. 12, fig. 14.

Material: 47 fragmentary leaves (compressions) have been collected. Only 4 of the smallest leaves are complete.

\section{Description}

The leaf (Pl. 6, figs. 1-5; text-fig. 8, A-E). The whole lamina is symmetrical. The form of the lamina is narrow elliptic or lanceolate. The length of the leaves is 6 to more than $15 \mathrm{~cm}$ and the width is 2 to $8 \mathrm{~cm}$. The apex of the leaf is acute and the base is acute (normal) or sometimes obtuse (normal). The leaf margin is toothed. It is serrate as the axes of the teeth are inclined to the tangent of the margin. The apical angle is acute. The apical side of the tooth is concave, the basal side is acuminate and the tooth normally ends in a mucro. The sinuses between the serrations are rounded. The simple teeth are all of one size and they are placed at sligthly irregular intervals. There is normally one tooth per secondary vein, but at the base no teeth or only very small ones correspond to the first two pairs of secondaries. The length of the teeth measured from the bottom of the sinus to the end of the mucro is 1 to $7 \mathrm{~mm}$. The leaf is petiolate and the length of the petiole is 1.0 to $1.8 \mathrm{~cm}$. The venation is craspedodromous. The midvein is stout, straight or gently curved and markedly tapering along length. The secondary veins are alternate or opposite and they arise from the midvein at an angle of 45 to $60^{\circ}$. There is only small variation from base to apex. The secondary veins are straight or gently curved and they run directly into the teeth of the leaf margin. The secondaries are rarely branched. The number of secondary veins per $10 \mathrm{~cm}$ primary vein varies depending on the size of the leaves. The largest leaves have about 8 per $10 \mathrm{~cm}$, the medium sized leaves have about 12 per $10 \mathrm{~cm}$ and the smallest leaves have about 16 per $10 \mathrm{~cm}$. In the juvenile leaves the distance decreases markedly toward the apex. The tertiary veins arise at a right angle from both the exmedial (lower) and the admedial 

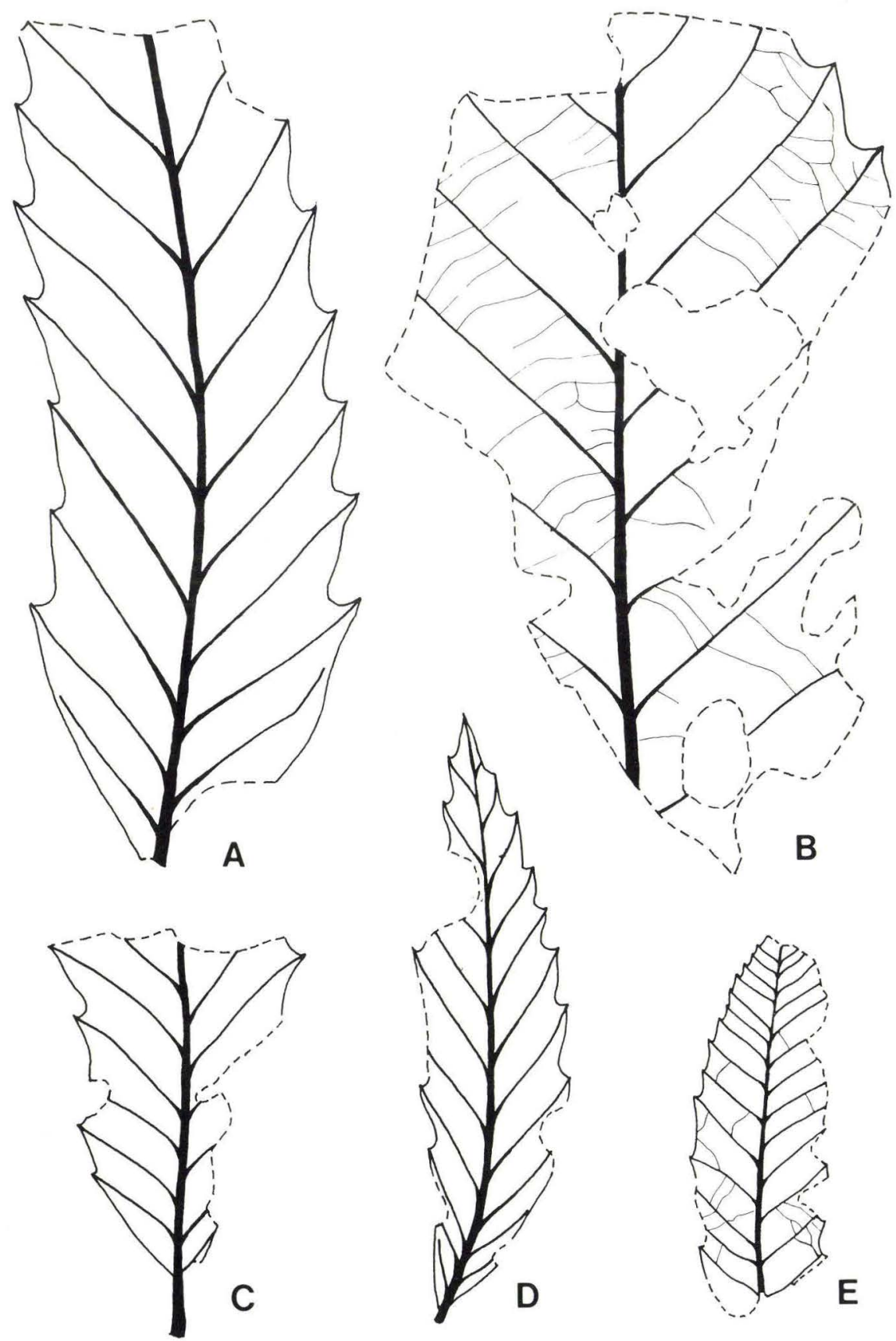

Fig. 8. Castanea atavia Unger. A-E: Shape and major venation of the leaves, $\times 1$. E: Juvenile leaf, $\times 1$. 
(upper) side of the secondary veins. The tertiary veins that arise on the admedial side of the secondaries and curve to join the midvein form a right angle to the midvein. The tertiary veins are predominantly alternate and there are 4 to 9 veins per $\mathrm{cm}$ secondary vein. The pattern of the tertiary veins is percurrent, the veins are simple or forked and they are oblique to the midvein. Higher order venation is unknown.

Epidermis. (P1. 7, figs. 2, 4, 6; text-figs. 9, 10). The upper epidermis has a thin cuticle and it is composed of 200 to 300 cells per $0.1 \mathrm{~mm}^{2}$. The shape of the cells is isodiametric or sligthly elongate and the length is 16 to 42 microns. The arrangement of the cells is tetragonal or pentagonal and the anticlinal cell wall pattern is straight or rounded. The cell walls are 1 to 3 microns thick and they are unpitted. The cells over the veins are linear elongate and they have oblique or square end walls. The length/width ratio is $1 / 1$ to $6 / 1$. The finer veins are reflected in the cuticle. The cells in the leaf margin are of the same type as the normal epidermis cells, but the cell walls are a little thickened. There are no trichome bases in the upper epidermis.

The cuticle of the lower epidermis is very thin and it is composed of 570 to 750 cells per $0.1 \mathrm{~mm}^{2}$. The shape of the cells in non venous areas is highly variable and they are 10 to 35 microns long. The arrangement of the cells is random. The anticlinal cell wall pattern is straight or occasionally

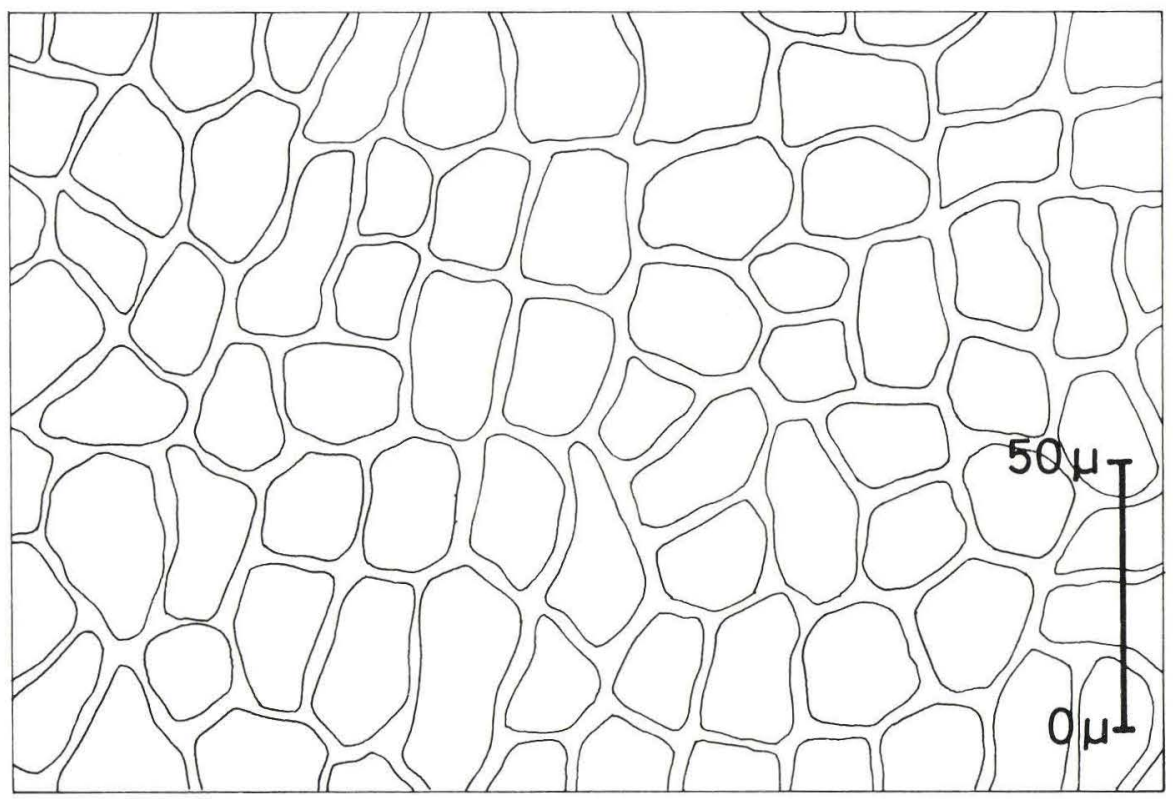

Fig. 9. Castanea atavia Unger. Upper epidermis . 
slightly undulate. The cell walls are 0.5 to 1.0 micron thick and they are unpitted. The cells over the veins are elongate and the length/width ratio is $1 / 1$ to $6 / 1$. The finer veins are reflected in the cuticle. Trichome bases are found both over the veins and in the areoles. There are 0 to 30 trichome bases per $0.1 \mathrm{~mm}^{2}$. The bases are sligthly elevated and they consist of one occasionally two thickened cells, 10 to 12 microns in diameter. They are surrounded by 6 to 8 radially arranged associated cells. Hairs are sometimes attached to the bases. Simple and double hairs are the most common type, but up to 7 hairs, arranged in a stellate fashion, are found attached to a single base. The length of the hairs are 100 microns or more. The stomata are variously orientated, undepressed and somewhat arranged in groups. There are 30 to 80 stomata per $0.1 \mathrm{~mm}^{2}$. The stomata are 17.0 to 27.2 microns long and 15.3 to 23.8 microns wide and apices are retuse. The stomatal slit is 30 to $50 \%$ of the stomatal length. The accessory cells are poorly differentiated. There are 4 to 7 in number and they are of the same size as the rest of the epidermis cells.

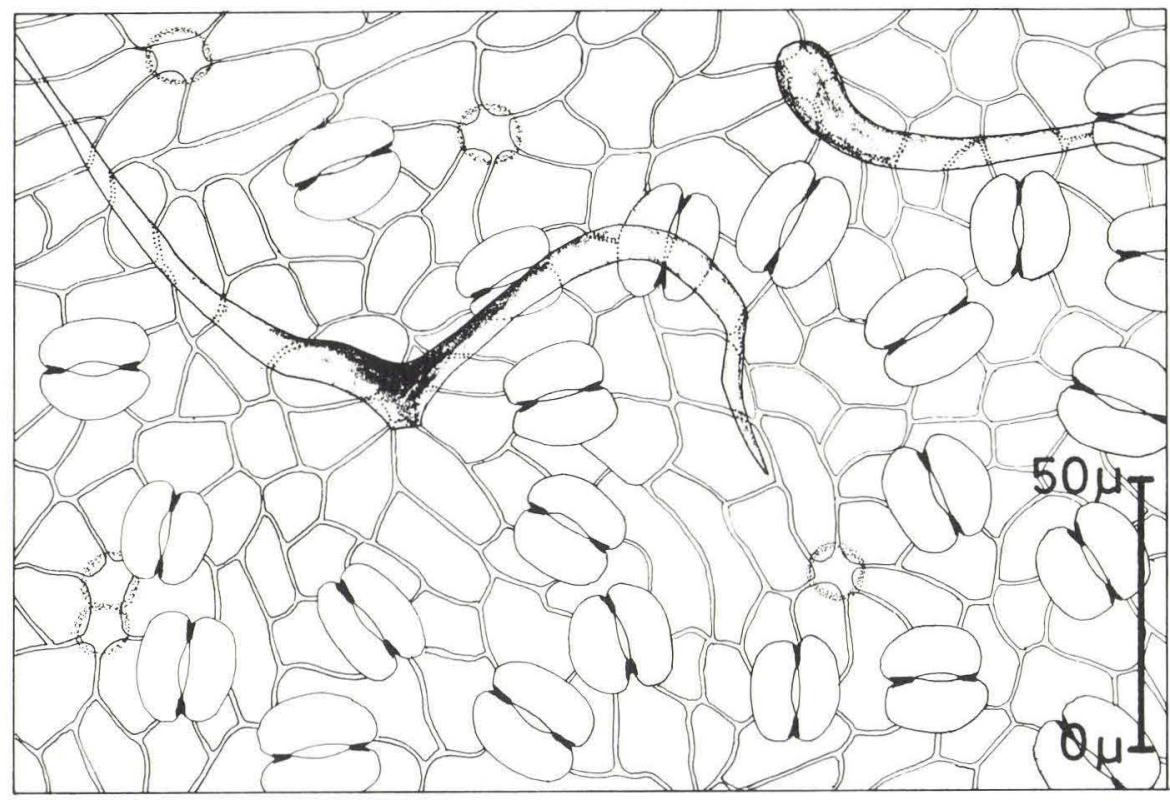

Fig. 10. Castanea atavia Unger. Lower epidermis with stomata and trichome bases, some of them with hairs still attached. Elongated cells over a vein are seen in the upper left corner of the figure. 


\section{Discussion}

A large number of Castanea leaves resembling the Søby leaves has been described from Tertiary deposits of Europe. Among these Castanea atavia Ung., Castanea kubinyi Kov. and Castanea ungeri Heer bear the largest resemblance. Ettingshausen (1872) unites these species. He points out that the species in question are all forms of $C$. atavia which lie within the same variation as is found to day in $C$. vesca Gärtn. (=C. sativa L.). This opinion has been sharply criticized by Stur (1867, p. 157) and Heer (1875, p. 93). Heer expresses the view that both $C$. ungeri and $C$. kubinyi are well established species, which should be maintained. Further he questions whether all leaves described as $C$. atavia belong to this species. He even questions the affinity to the genus Castanea.

Menzel (1906, p. 61) mentions the inexpediency in Ettingshausen's adoption of Ungere epithet for his $C$. atavia (sensu novo), because Unger's type specimens (Unger 1851, pl. 5-7) are not well defined. However, Menzel does not doubt the correctness in uniting the species $C$. ungeri, $C$. kubinyi and $C$. atavia.

Reichenbach (in Kräusel 1919, pp. 129-130) deals with two forms of Castanea leaves, the kubinyi-form and the atavia-form in the Tertiary deposits of Silesia. Both forms are referred to $C$. atavia, but he is aware of the fact that it has not been properly proved.

Berger (1952, p. 92) states that only a smaller part of the leaves decribed as $C$. kubinyi by Kovats (1856) can be maintained as Castanea leaves. The main part of these leaves belong, according to Berger, to a fossil Quercus species that corresponds to the extant Quercus libani Oliv. and he changes the name to Quercus kubinyi (Kov.) Berger.

Berger (1952, p. 90) holds the opinion that it is only possible in the fossil record to distinguish clearly between typical Castanea leaves and typical Quercus leaves and that a number of intermediar forms will always remain impossible to classify.

The morphological variation within the examined material from Søby ranges from typical Castanea leaves to leaves close to Quercus kubinyi. The typical Castanea leaves of this material have an epidermis identical with the epidermis of the less typical ones. This makes it clear that the Søby leaves belong to one and the same species. The main part of the leaves are typical Castanea leaves and as the epidermis is very similar to the epidermis of the recent Castanea sativa the fossils must belong to the genus Castanea.

The Søby leaves are identical with Castanea atavia Ung., but as descriptions of the epidermis of these fossils are scarce the determination is based exclusively on morphological characteristics. 
Ferguson (1971, p. 101) describes a number of leaves of the Castanea type, taxon XIV (syn. Castanea atavia Ung.). The description of both morphology and anatomy of the leaves shows a so high degree of similarity to the Søby species that the two taxa must be considered identical. Further, the author agrees with Ferguson (1971, p. 102) when he claims that Castanopsis fucinervis (Rossm.) Kr. et Wld. (Kräusel and Weyland 1950; Jähnischen 1956) has an epidermis similar to the epidermis of $C$. atavia, but they can certainly not be considered identical. The most evident difference is the marked thickening of the dorsal walls of the guard cells in Castanopsis fucinervis (Kräusel and Weyland 1950, p. 45; Jähnischen 1956, p. 143).

\section{Comparison with recent material}

The fossil leaves from the Søby Flora have been compared to a number of recent species of the genera Castanea and Quercus which bear morphological resemblance to the fossils. The leaves of Castanea sativa $\mathrm{L}$. have a morphology and a morphological variation very similar to the Søby leaves, but also $C$. dentata (Marsh.) Borkh., C. crenata Sieb. et Zucc. and $C$. mollissima Blume have many features in common with the fossils. Further, the smallest of the Søby leaves are comparable to Quercus castaneifolia C. A. Mey. and $Q$. libani Oliv.

The epidermis of the above-mentioned species have been submitted to careful examination which shows that the epidermis of $C$. sativa bears a remarkable resemblance to the epidermis of the fossils. This leads to the conclusion that as far as the leaves are concerned, $C$. sativa is the living species most closely related to C. atavia.

Family Hamamelidaceae

Genus Liquidambar L.

Liquidambar europaea A. Braun

(Pl. 8, figs. 2, 4-6; text-fig. 11, A-D; text-figs. 12, 13).

1836: Liquidambar europaeum A. Braun - Braun in Buckland, p. 513.

1845: Liquidambar europaeum A. Braun - Braun, p. 170.

1847: Liquidambar europaeum A. Braun - Unger, p. 120, pl. 35, figs. 1-5.

1847: Acer parschlugianum Unger - Unger, p. 132, pl. 43, fig. 5.

1856: Liquidambar europaeum A. Braun - Heer, p. 6, pl. 51, figs. 2-12, pl. 52, figs. $1-9$.

1860: Liquidambar europaeum A. Braun - Ludwig, p. 89, pl. 15, figs. 6, pl. 25, figs. $1-4$.

1903: Liquidambar europaeum A. Braun - Engelhardt, p. 277, pl. 3, figs. 16, 17, pl. 4, fig. 4 . 


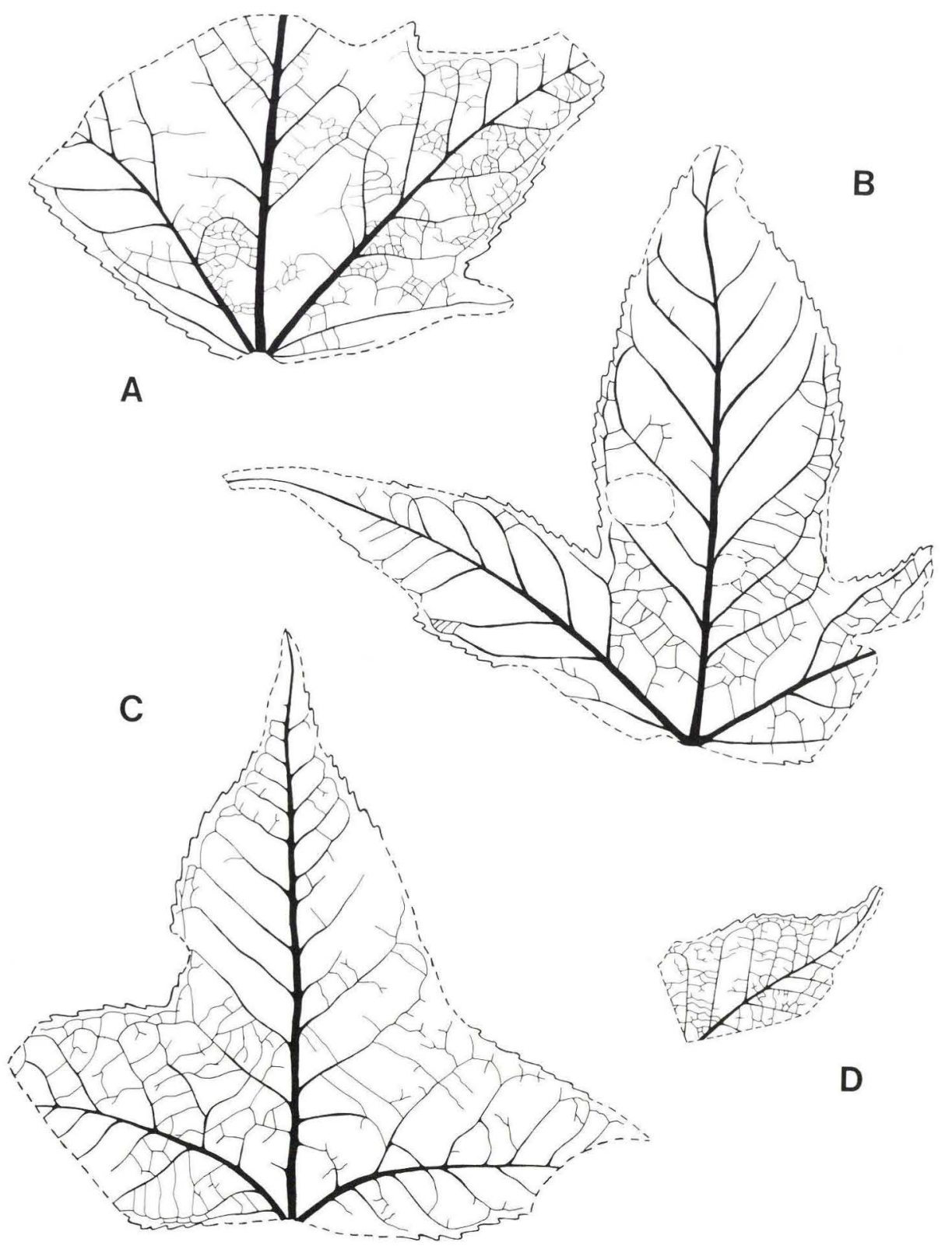

Fig. 11. Liquidambar europaea A. Braun. A-D: Shape and venation of the leaves, $\times 1$. 
Material: 23 very fragmentary leaves (compressions) have been collected. Only 4 of these are nearly complete. 13 leaves are in such a state of preservation that it can be decided whether they are 3-lobed or 5-lobed. 9 are 3 -lobed and 4 are 5-lobed.

\section{Description}

The leaf. (Text-fig. 11, A-D). The leaves are palmate with 3 or 5 lobes (rarely 4 lobes). The length of the lamina from the base to the apex of the median lobe is 6 to $9 \mathrm{~cm}$. The width of the leaf from one apex to the other of the upper pair of lateral lobes is 7 to $13 \mathrm{~cm}$. The median lobe is triangular or parallel sided in the lower third and it may even be slightly contracted at its base. The upper pair of the lateral lobes is a little smaller than the median lobe. They are triangular, long and slender (5-lobed leaves) or short and broad (3-lobed leaves), but this relation of shape to number of lobes is not always quite clear. The lower pair of lateral lobes is, if present, considerably smaller than the other lobes. In rare cases only one of the lower lobes may be developed. The leaf base is cordate or rounded. The leaf margin is serrate and the teeth are all of one size. They are rounded, separated by angular sinuses and extended on the complete margin. The teeth are 0.3 to $0.8 \mathrm{~mm}$ across and there are about 25 teeth per $5 \mathrm{~cm}$ leaf margin. The petiole is never preserved in the Søby leaves. The venation is actinodromous. There are 5 primary veins markedly tapening along length. The central primary vein is straight. The upper pair of lateral primary veins arises at an angle of 35 to $55^{\circ}$ to the central primary vein. The angle increases as the lateral veins curve abaxially into the lobes. The lower pair of lateral primary veins arises on the baseoscopic side of the upper pair of lateral primary veins a few $\mathrm{mm}$ from the junction with central primary vein. These veins are considerably thinner than the normal primary veins and in 5-lobed leaves they run into the small lobes. In 3-lobed leaves they form anastomoses with the secondary veins that arise on the baseoscopic side of the upper lateral primary veins. The secondary venation is camptodromous. The secondary veins are alternate or opposite and they arise at an angle of 40 to $55^{\circ}$ to the primary veins. The distance between the secondaries is variable, but in general it gradually decreases toward the apex of the lobes. The veins are abruptly curved and the loop-forming branches are enclosed by tertiary vein arches. The tertiary veins normally arise at a right angle to the secondary veins. The pattern of tertiary veins is percurrent, they are simple or forked and there are 6 to 12 veins per $\mathrm{cm}$ secondary vein. Higher order venation is insufficiently preserved for description. 
Epidermis. (Pl. 8, figs. 2, 4-6; text-figs. 12, 13). The upper epidermis has a thin cuticle and it is composed of 120 to 160 cells per $0.1 \mathrm{~mm}^{2}$. The shape of the cells is isodiametric or slightly elongate and the length is 26 to 44 microns. The arrangement of the cells is tetragonal or pentagonal and the anticlinal cell wall pattern is straight or rounded. The cell walls are 1.5 to 2.0 microns thick and they are unpitted. The cells over the veins are elongate and they have oblique or square end walls. The length/width ratio is $2 / 1$ to $4 / 1$. The finer veins are not reflected in the cuticle. The cells in the leaf margin have the same shape as the normal cells in the upper epidermis, but generally they are smaller and the cell walls are thickened. The highest number of cells is found in the teeth where there are about 300 cells per $0.1 \mathrm{~mm}^{2}$.

The cuticle of the lower epidermis is thin and it is composed of 250 to 350 cells per $0.1 \mathrm{~mm}^{2}$. The shape of the cells in non venous areas is isodiametric or slightly elongate and the length is 16 to 34 microns. The arrangement of the cells is random. The anticlinal cell wall pattern is markedly undulate and there are 4 to 8 lobes per cell. The wave length is 6 to 10 microns and the wave amplitude is up to 8 microns. The cell walls are 1.0 to 1.5 microns thick and they are unpitted. The cells over the veins are elongate and the length/width ratio is $2 / 1$ to $5 / 1$. The cell walls are

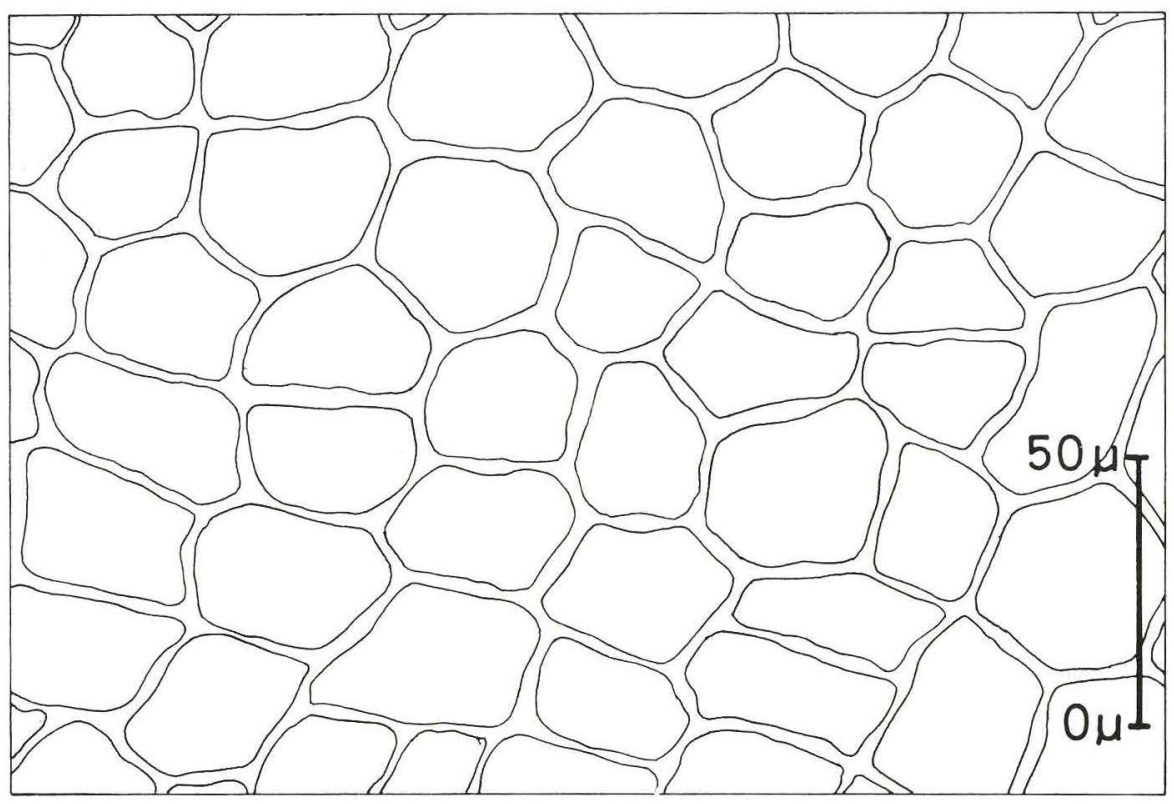

Fig. 12. Liquidambar europaea A. Braun. Upper epidermis. 
straight. The finer veins are reflected in the cuticle. The stomata are variously orientated, undepressed and more or less equidistant. There are approx. 15 stomata per $0.1 \mathrm{~mm}^{2}$. The stomata are 16 to 22 microns long and 9 to 13 microns wide. The stomatal slit is approx. $50 \%$ of the stomatal length. The stomatal complex is of the brachyparacytic type with the accessory cells not completely enclosing the guard cells. The accessory cells are elongated parallel to the axis of the guard cells and they are of the same size or a little smaller than the rest of the epidermis cells. The cells in the leaf margin are linear elongate and they are arranged in 6 to 8 rows parallel to the leaf margin. The cell walls are straight.

\section{Discussion}

The S $\varnothing$ by leaves are referred to the very common Liquidambar europaea A. Braun, as all the morphological characteristics are identical with this fossil species.

Bủžek (1971, p. 55) points out that specimens from several European localities show that during the Tertiary the mutual relationship of the 3and 5-lobed leaves gradually changed. In the Lower Miocene 3-lobed leaves distinctly predominate and 5-lobed leaves are represented only negligibly.

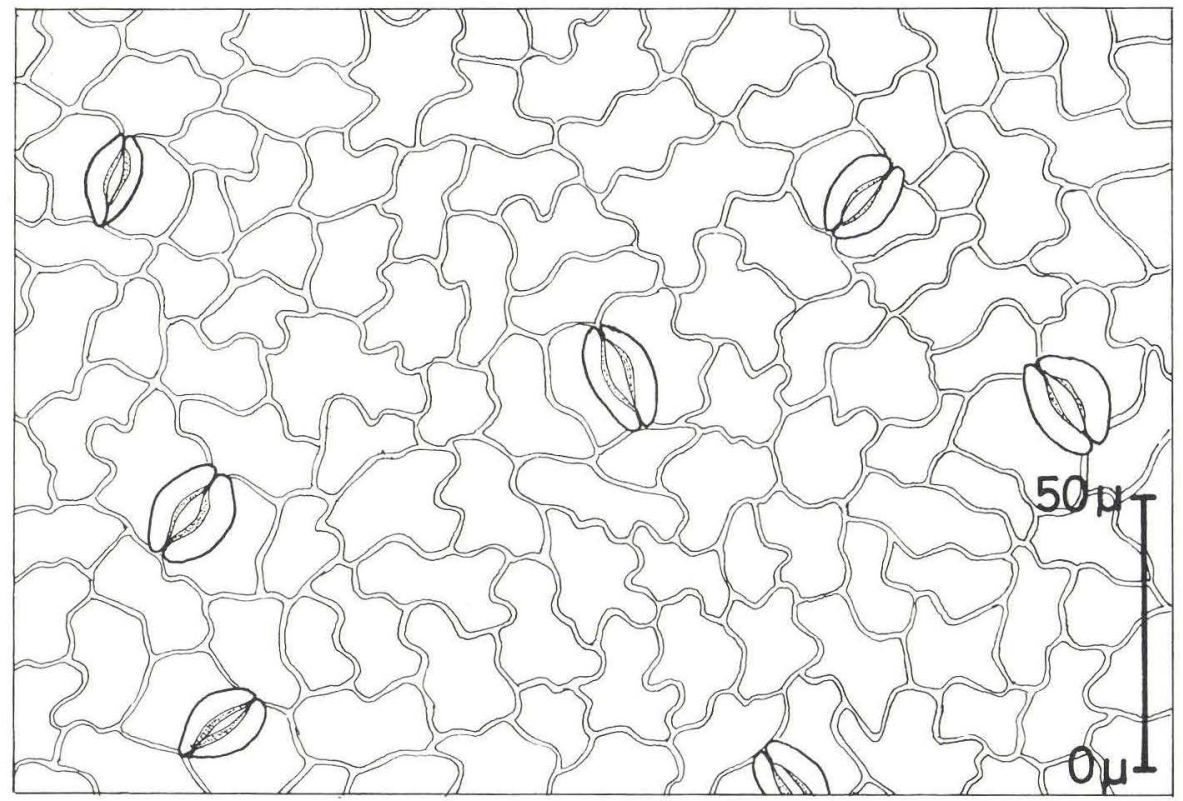

Fig. 13. Liquidambar europaea A. Braun. Lower epidermis with stomata in non venous area. 
The latter become more abundant only in the Upper Miocene, predominating absolutely in the Pliocene. Even if well preserved Søby material is very limited it is interesting to note that 9 specimens are 3-lobed and 4 are 5-lobed.

Ferguson (1971, p. 168) describes a species of the genus Liquidambar (taxon XXX, syn. Liquidambar europaea A. Braun). These leaves are morphologically identical with the S $\varnothing$ by levaes. The description of the epidermis is very similar to the description here given on L. europaea and it cannot be doubted that the two species are identical.

Leaves of $L$. europaea have previously been reported from the Neogene Tertiary Lignites of Central Jutland (locality Moselund) by Mathiesen (1975, p. 41, fig. 23, A, B). Both 3- and 5-lobed leaves are illustrated.

\section{Comparison with recent material}

The fossil material from Søby has been compared to 3 living species of the genus Liquidambar. The leaves of $L$. formosana Hance are normally 3-lobed. They may bear a certain resemblance to the 3-lobed leaves from Søby, but the epidermis has a different appearence. The most pronounced difference is the markedly pitted cell walls in $L$. formosana. The leaves of L. styraciflua $\mathrm{L}$. and $L$. orientalis Mill. have a very similar shape and venation. They both have 5-lobed and occasionally 3-lobed leaves. L. orientalis has in general smaller leaves than L. styraciflua, but both species are morphologically closely comparable to $L$. europaea. The epidermis of $L$. orientalis has very broad stomata and the concentration of the stomata is much higher than in the epidermis of L. europaea. Besides, the upper epidermis of $\mathrm{L}$. orientalis has markedly undulate cell walls. A comparison of the epidermis of $L$. europaea and $L$. styraciflua shows a very high degree of similarity in the general appearence. Only smaller differences exist. The upper epidermis of L. styraciflua has sometimes slightly undulate cell walls and the concentration and the size of the stomata is slightly larger.

This comparison shows that the leaves of L. europaea and L. styraciflua both in morphology and in anatomy are very similar and that we are dealing with two closely related but distinct species. 

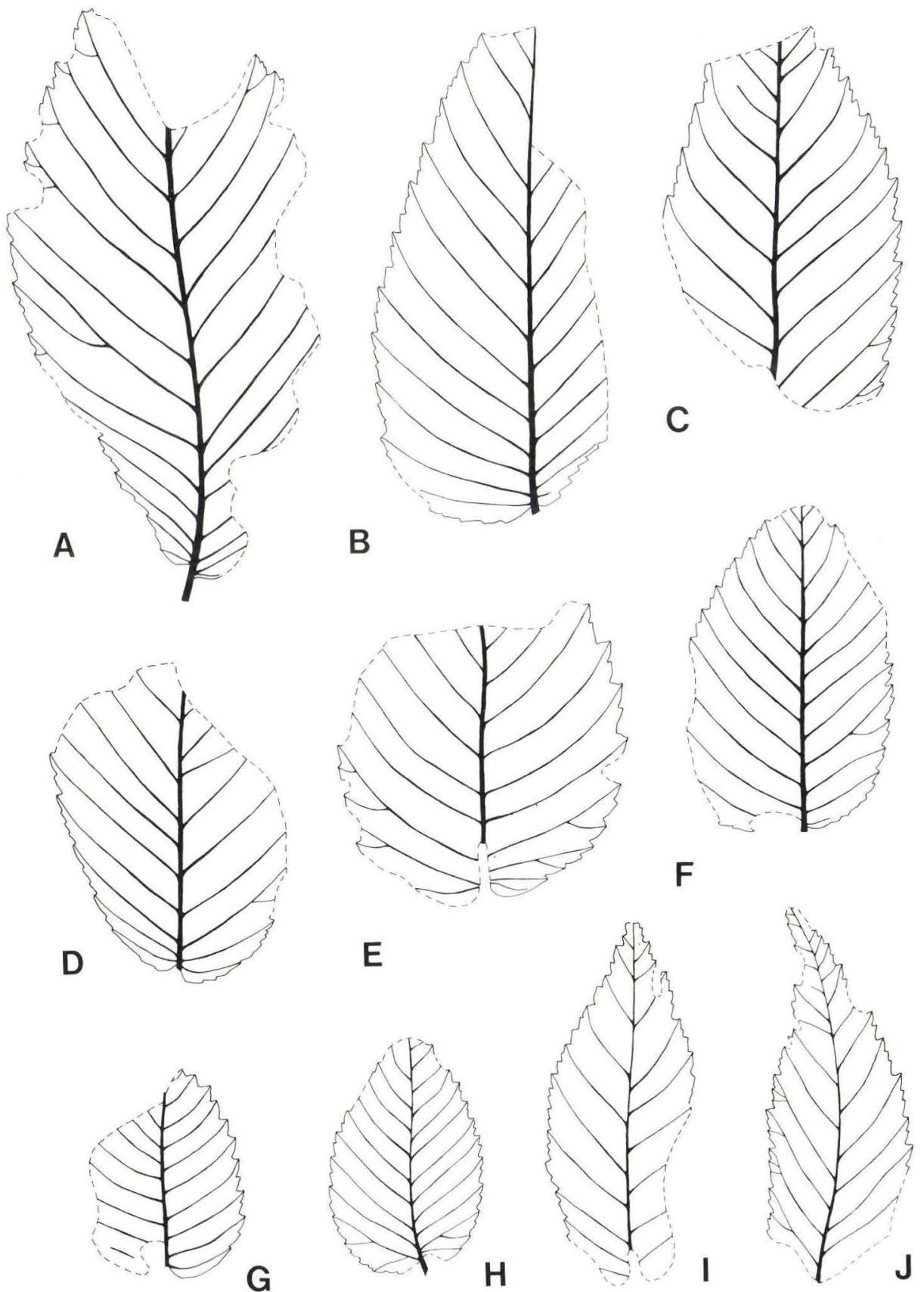

Fig. 14. Ulmus pyramidalis Goeppert. A-J: Shape and venation of the leaves, $\times 1$. 
Family Ulmaceae

Genus Ulmus L.

Ulmus pyramidalis Goeppert

(Pl. 9, figs. 1-10; pl. 10, figs. 2, 4-6; text-fig. 14, A-J; text-figs. 15, 16).

1845: Ulmus bronni Unger - Unger, pp. 100-101, pl. 26, fig. 1.

1845: Ulmus longifolia Unger - Unger, p. 101, pl. 26, fig. 5.

1855: Ulmus pyramidalis Goepp. - Goeppert, p. 28, pl. 13, figs. 10-12.

1866: Ulmus bronni Unger - Ettingshausen, p. 62, pl. 17, figs. 9, 10.

1866: Ulmus longifolia Unger - Ettingshausen, p. 62, pl. 18, figs. 7, 9-11.

1866: Ulmus plurinervia Unger - Ettingshausen, p. 63, pl. 18, figs. 12, 13.

1866: Ulmus minuta Goepp. - Ettingshausen, p. 63, pl. 18, figs. 21, 22.

1866: Ulmus brauni Heer - Ettingshausen, p. 64, pl. 18, figs. 23-25, 27.

1866: Planera ungeri Ett. - Ettingshausen, p. 65, pl. 18, figs. 14-16.

1919: Ulmus longifolia Unger - Reimann in Kräusel, pp. 80-83, pl. 6, figs. 9, 10, 12,14 , pl. 7 , figs. $1-4,6-9,11,12$, pl. 9, figs. $8-10$.

1939: Ulmus longifolia Unger - Mädler, pp. 86-88, pl. 8, fig. 1.

1954: Ulmus longifolia Unger sensu novo - Hantke, pp. 59-62, pl. 6, figs. 5-19, pl. 7.

1963: Ulmus longifolia Unger - Jung, pp. 137-138, pl. 36, figs. 37-42.

1969: Ulmus pyramidalis Goepp. - Knobloch, pp. 103-105, pl. 35, fig. 10, pl. 50, figs. $1,4,5,9-11$, pl. 51 , figs. 1,7 , pl. 52 , figs. $1,6,7,9$, pl. 53 , figs. $1,6,11$, pl. 73 , fig. 8 , pl. 77 , fig. 9 .

1971: Ulmus pyramidalis Goepp. - Bůžek, pp. 56-57, pl. 19, figs. 1-18, pl. 20, figs. $1-17$, pl. 21 , figs. $1-8$.

Material: 102 more or less fragmentary leaves (compressions) have been collected. 14 of these are almost complete. This material is characterized by not being transparent when treated after the Collodium-film method.

\section{Description}

The leaf. (PI. 9, figs. 1-10; text-fig. 14, A-J). The whole lamina is asymmetrical or occasionally nearly symmetrical. The form of the lamina is narrow ovate to ovate or sometimes elliptic. The variation of the leaves is wide. It ranges from very slender leaves to rather broad ones within the above-mentioned forms. The length of the lamina is 2.1 to a little more than $8 \mathrm{~cm}$. The width is 1.3 to $4.6 \mathrm{~cm}$. The apex of the leaf is acuminate to attenuate. The base is always asymmetrical and it is normally chordate or rounded. The leaf margin is toothed. It is serrate as the axes are inclined to the tangent of the margin. The apical angle is acute or obtuse. The apical side of the tooth is concave and the basal side is convex or acuminate. The sinuses between the serrations are angular. The teeth are compound. The major teeth are followed by 1 to 2 smaller teeth. Simple teeth are found in the apical part of some of the leaves. The teeth are extended on the 
complete margin and the major teeth are placed at almost regular intervals. The major teeth are 0.4 to $1.6 \mathrm{~mm}$ across. The leaf is petiolate and the petiole is up to $1.0 \mathrm{~cm}$ long. The venation is craspedodromus. It is simple as all the secondary veins and their branches terminate at the margin. The midvein is moderate, straight or slightly curved and gently tapering along length. The secondary veins are alternate and they arise from the midvein at an angle of 30 to $60^{\circ}$. The highest values are found near the base and the smallest are found near the apex. In the middle and major part of the leaf the angle of divergence is rather constant, approx. $45^{\circ}$. The secondary veins are straight or gently curved. They may be recurved near the base. The secondary veins run directly into the major teeth. Occasionally they branch and both branches enter the major teeth. The branching may occur at any distance from the midvein. There are 8 to 11 secondary veins per $5 \mathrm{~cm}$ primary vein. The tertiary veins arise at a right angle from both the exmedial (lower) and the admedial (upper) side of the secondary veins. The tertiary veins that arise on the admedial side of the secondaries and curve to join the midvein form a right angle to the midvein. The tertiary veins are predominantly alternate, and there are 6 to 8 veins per $\mathrm{cm}$ secondary vein. The pattern of the tertiary veins is percurrent, the veins are simple or forked and they are oblique to the midvein. The tertiary veins that arise on the

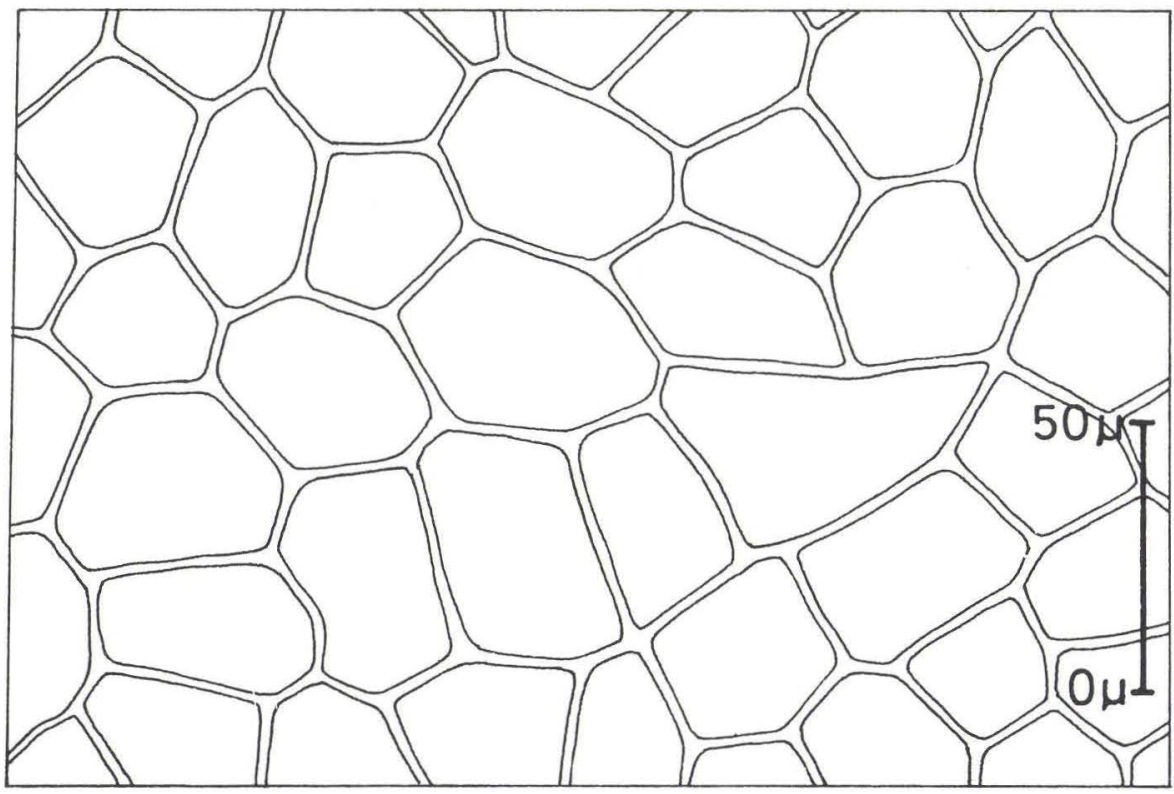

Fig. 15. Ulmus pyramidalis Goeppert. Upper epidermis. 
exmedial side of the secondaries near the leaf margin enter the minute teeth. Higher order venation is occasionally preserved. The areoles are well developed. The arrangement is orientated, and the shape of the areoles is quadrangular, pentagonal or polygonal. The size of the areoles is medium to small. The veinlets are simple or branched.

Epidermis. (Pl. 10, figs. 2, 4-6; text-figs. 15, 16). The cuticle of the upper epidermis is thin and it is composed of 50 to 140 cells per $0.1 \mathrm{~mm}^{2}$. The number of cells per unit area is rather constant within the same leaf, but it varies considerably from one leaf to another (probably depending on whether the leaf grew in sunlight or in shade). The shape of the cells is isodiametric or slightly elongate. The assumed shade leaves have cells 35 to 75 microns long while the assumed sunlight leaves have cells 18 to 40 microns long. The arrangement of the cells is on the whole pentagonal and the anticlinal cell wall pattern is straight or rounded. The cell walls are 2.0 to 2.5 microns thick. The cells over the veins are elongate and they have square or oblique end walls. Surface ornamentation is absent. Trichome bases are occasionally found near or over the veins. They consist of one simple unthickened cell 12 to 18 microns across. The bases are surrounded

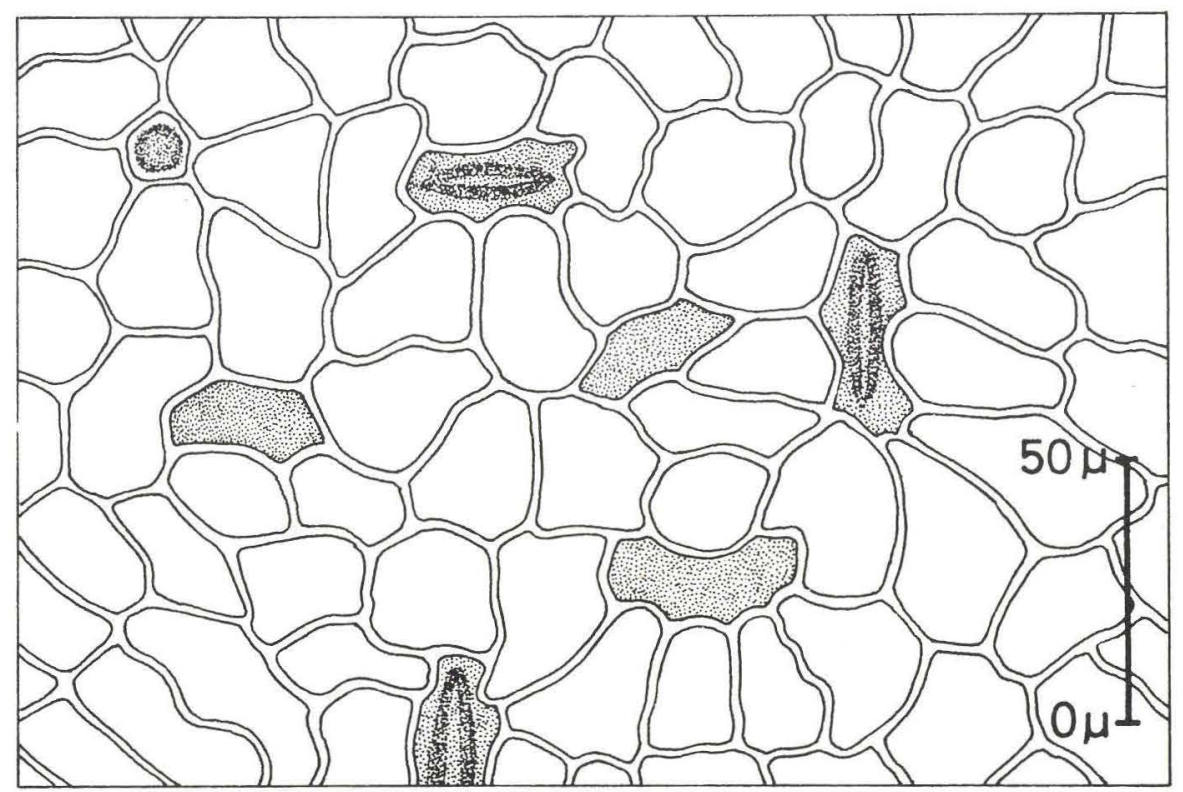

Fig. 16. Ulmus pyramidalis Goeppert. Lower epidermis with trichome base and partly preserved sunken stomata. In the lower left corner of the figure elongated cells over a vein are seen. 
by 6 to 8 radially arranged associated cells. The bases are widely spaced and there has been no observation of attached hairs.

A well developed palisade is found below the upper epidermis. The diameter of the palisade cells is 9 to 20 microns and there are 500 to 600 cells per $0.1 \mathrm{~mm}^{2}$.

The cuticle of the lower epidermis is thin and it is composed of 180 to 250 cells per $0.1 \mathrm{~mm}^{2}$. The shape of the cells is isodiametric or slightly elongate and they are 20 to 40 microns long. The arrangement of the cells is random and the anticlinal cell wall pattern is rounded or weakly undulate. The cell walls are 1.5 to 2.0 microns thick and they have no special ornamentation. The cells over the veins are linear elongate and the end walls are square or oblique. The anticlinal cell wall pattern is straight and the lenght/width ratio is $2 / 1$ to $8 / 1$. The finest veins are reflected in the cuticle. Surface ornamentation is absent in the entire lower epidermis. The stomatal complex is only partly preserved in the Søby material. The guard cells are never preserved but exceptionally the stomatal aperture and its nearest surroundings are faintly seen. The arrangement of the accessory cells shows that the stomata are variously orientated, sunken and more or less equidistant. There are approx. 16 to 26 stomata per $0.1 \mathrm{~mm}^{2}$. The size of the stomata is not known. The opening between the accessory cells over the sunken stomata is 26 to 30 microns long and 10 to 16 microns wide. The accessory cells are not differentiated in any way from the normal epidermal cells. They are 5 to 8 in number. Trichome bases are also present in the lower epidermis. They occur singly and are mainly confined to venation. The unthickened base is 10 to 14 microns across and it is surrounded by 6 to 7 radially arranged associated cells. At rare intervals hairs are found attached to the bases. They are simple unicellular hairs approx. 75 microns long.

In some of the leaves a residue of spongy mesophyll is found between the palisade and the lower epidermis.

\section{Discussion}

Leaves of this type are well known from Tertiary deposits of Europe and they have previously been described as Ulmus longifolia Unger. Knobloch (1969, p. 104) and Bǔžek (1971, p. 57) have pointed out that this name is the younger homonym of the recent $U$. longifolia Rafinesque (1836) and that the name $U$. pyramidalis Goeppert (1855) must be given priority. For further discussion of the nomenclature see Knobloch (1969).

The variation of the Søby leaves is very large. It ranges from long ovate leaves to small and broad leaves. The extremely slender leaves as illustrated 
by Hantke (1954, pl. 6, fig. 10) have never been found in the Søby Flora. A classification of such material based exclusively on morphology is obviously very difficult.

In his work on the Ulmus species from the Tertiary of Silecia Reimann (in Kräusel 1919, p. 76-89) comes to the conclusion that two form-groups exist, $U$. longifolia and $U$. carpinoides. But no exact criteria are mentioned on how to separate the two species.

Hantke (1954) describes $U$. longifolia Unger sensu novo and includes the smaller and broader leaves in this species. He sincerely doubts Reimann's division of the Silecian Ulmus leaves into two species and points out that the Schrotzburger material only contains one Ulmus species and that both large and slender leaves and smaller and broad leaves are found on the same twigs in the deposit.

Jung (1963, p. 137) presents the variation of $U$. longifolia by giving the frequency of 4 forms within the species (form "longifolia": $25 \%$, form: "pyramidalis": $52 \%$, form: "carpinoides": $20 \%$ and form "minuta": $3 \%$ ). Roughly estimated the fragmentary Søby material has the same variation as given by Jung, but the number of the form "longifolia" seems to be smaller. Jung is of the opinion that the material described ought to be considered as one species, unless evidence from the cuticle may justify a separation, or more that one fruit type with definitive relation to the leaves is found.

In order to clarify whether one or more species is present in the Søby material, the cuticles of all the different leaf types were examined. 11 leaves representing the total variation within the material were investigated and 56 cuticle preparates were made. The variation of the investigated cuticular material lies within the description here given on the epidermis and no basis was found for a division of the material. Thus it must be concluded that only one Ulmus species is present in the Søby Flora.

Fossil leaves of Ulmus longifolia Unger from Bilin (topotypical specimens) have been submitted to a short study by Kvaček (personal communication, 1975). He gives a short description of the cuticle and concludes: "In general the structure (of the cuticle) of the specimens from Bilin corresponds to yours (Søby leaves)". This information, combined with evidence from the leaf variation, forms the basis for determining the Søby leaves as Ulmus pyramidalis Goeppert.

The epidermis of fossil Ulmus leaves has been described by Ferguson (1971, p. 105), taxon XV, syn. Ulmus carpinoides Goeppert. This epidermis differs from the epidermis of the Søby leaves. The upper epidermis has markedly undulate cell walls, and no trichome bases are reported. In the lower epidermis the cell walls are undulate, with an amplitude up to 9 
microns. In the Søby leaves the cell walls of the lower epidermis are rounded or weakly undulate. The stomatal complex in Ferguson's taxon XV is quite different from that of the Søby leaves, thus the guard cells are well preserved, they are not sunken and they are surrounded by 4 to 5 symmetrically arranged accessory cells; besides, no trichome bases have been observed in the lower epidermis.

This marked difference in the cuticle of the two Miocene Ulmus species, $U$. pyramidalis and taxon XV (syn. $U$. carpinoides), is highly interesting in relation to the problem whether $U$. pyramidalis and $U$. carpinoides should be kept apart or not. Unfortunately Ferguson does not illustrate the morphology of the leaf (No. 4147) that has provided the cuticle material shown in plate 12, figs. D, E, but if Ferguson's leaves are true Ulmus and even $U$. carpinoides the problem might approach a solution. However, far more material is needed for drawing such conclusions. Unfortunately, a cuticular revision of the genus Ulmus is not within the framework of this paper.

Hantke (1954) describes the upper epidermis of Ulmus longifolia Unger sensu novo. This epidermis is similar to, but not quite identical with the upper epidermis of the Søby leaves, but Kvaček (personal communication) considers it to fall within the natural range of this species. No details are known on the lower epidermis.

\section{Comparison with recent material}

The fossil leaves of Ulmus pyramidalis from the Søby Flora have been compared morphologically to 18 species of recent Ulmus available to the author. A reference of the fossils to any particular of these species has not been possiple. Only a general morphological resemblance to a number of the species has been found. The epidermis of 12 of the recent species have been examined and compared with the epidermis of the fossil. The highest degree of similarity with the epidermis of the fossil is found in Ulmus alata Michx. But as the epidermis of $U$. pyramidalis is not known in all details, conclusions on the specific relationship is considered premature.

Family Salicaceae

Genus Salix L.

Salix lavateri A. Braun sensu Hantke 1954

(Pl. 11, figs. 1-12; pl. 12, figs. 1-6; text-fig. 17, A-I; text-figs. 18, 19).

1851: Salix lavateri A. Braun - Braun in Stizenberger, p. 78.

1856: Salix lavateri A. Braun - Heer, p. 28, pl. 66, figs. 1-12. 

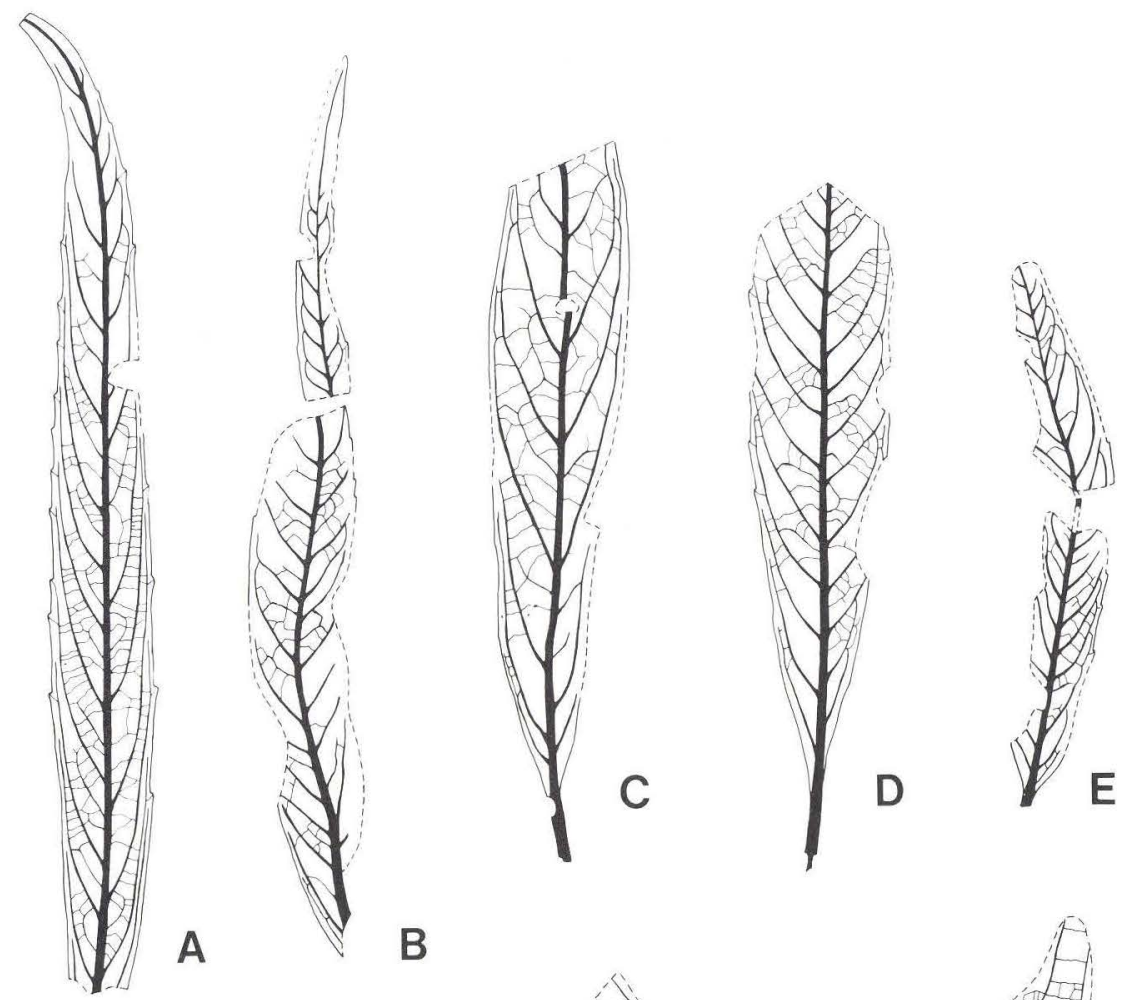

A
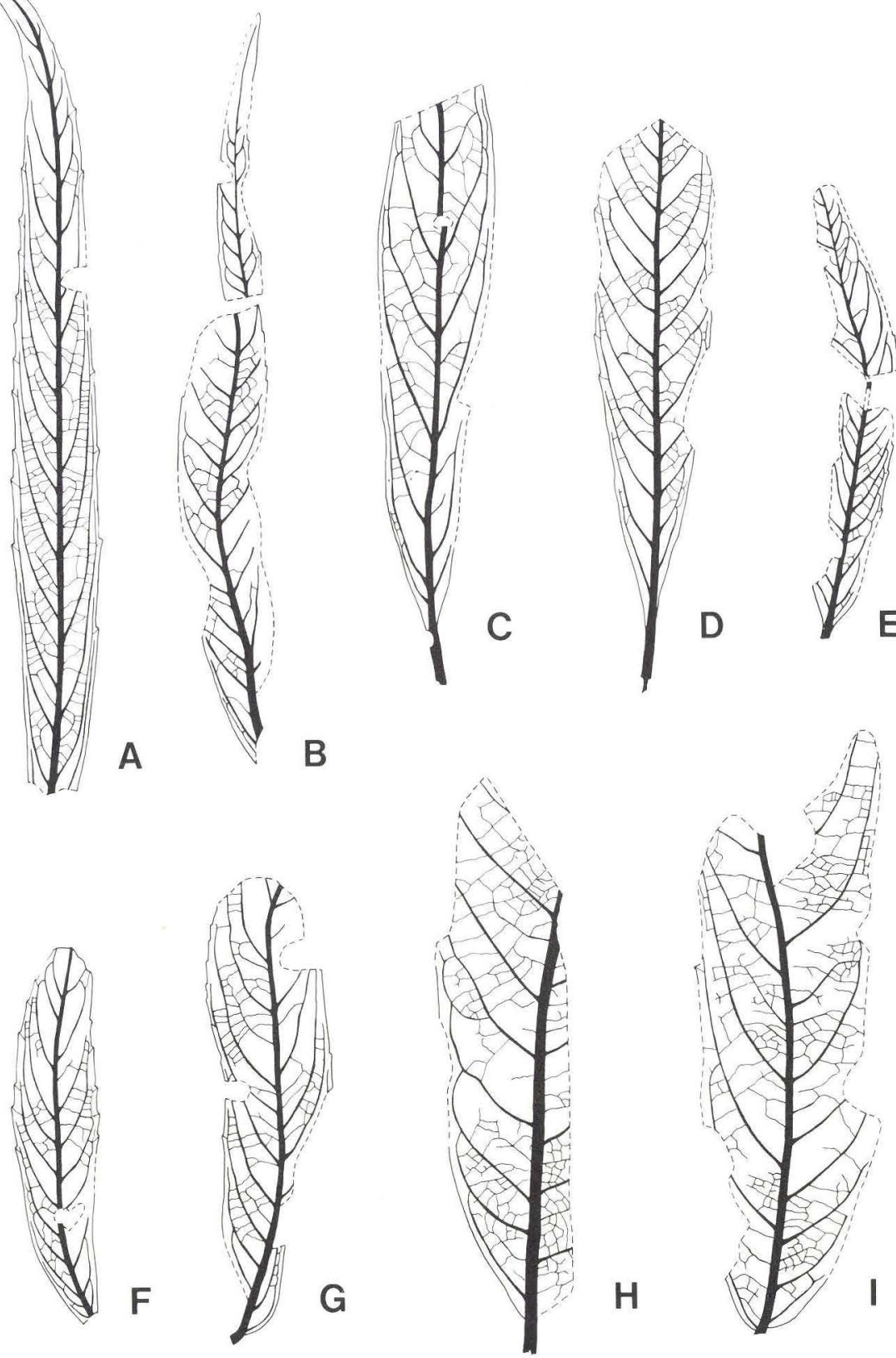

Fig. 17. Salix lavateri A. Braun sensu Hantke 1954. A-I: Fragmentary leaves showing venation and variation in morphology, $\times 1$. 
1856: Salix acutissima Goepp. - Heer, p. 29, pl. 66, fig. 14.

1856: Salix denticulata Heer - Heer, p. 30, pl. 68, figs. 1-4.

1856: Salix longa A. Braun - Heer, p. 31, pl. 69, figs. 12-14.

1856: Salix media Heer - Heer, p. 32, pl. 68, figs. 14-19.

1856: Salix tenera A. Braun - Heer, p. 32, pl. 68, figs. 7-13.

1856: Salix integra Goepp. - Heer, p. 32, pl. 68, figs. 20-22.

Material: 114 more or less fragmentary leaves (compressions) have been collected. Only 10 of these are complete.

\section{Description}

The leaf. (Pl. 11, figs. 1-12; text-fig. 17, A-I). The lamina is symmetrical with a symmetrical base. The form of the lamina is linear or narrowly lanceolate. The smallest complete leaf is $6.0 \mathrm{~cm}$ long and $0.8 \mathrm{~cm}$ wide, the largest is $11.0 \mathrm{~cm}$ long and $1.1 \mathrm{~cm}$ wide, but fragmentary material indicates the presence of both larger and smaller leaves (width up to $2.2 \mathrm{~cm}$ ). The width of the lamina gradually decreases and the leaf ends in an acute or attenuate apex. The base is acute, cuneate or decurrent, but in some of the large and broad leaves the base may almost be rounded. The leaf margin is serrate. The teeth are small, 0.2 to $0.5 \mathrm{~mm}$ across, and the axes are inclined to the tangent of the margin. The apex of the teeth is rounded and the sinuses between the serrations are angular. The teeth are placed at irregular intervals. They are of one size group, widely spaced and there are 4 to 10 teeth per $5 \mathrm{~cm}$ leaf margin. In the basal part of the leaf the teeth are very small or totally missing. The leaf is petiolate and the petiole is up to $1.6 \mathrm{~cm}$ long. The venation is camptodromous. The midvein is massive, normally curved and gently tapering along length. The secondary veins are alternate and they arise from the midvein at an angle of 30 to $60^{\circ}$. The secondary veins are uniformly curved and near the leaf margin they are interconnected by fine extensions of secondary or tertiary veins. There are 5 to 10 secondary veins per $5 \mathrm{~cm}$ midvein. The intersecondary veins are composite. They arise at a slightly greater angle to the midvein than the secondaries and there are 1 to 3 per intercostal area. The tertiary veins arise at a right angle from the admedial (upper) side of the secondaries and at a right or acute angle from the exmedial (lower) side. The tertiary veins that arise on the admedial side of the secondaries and curve to join the midvein normally form an acute angle to the midvein. The tertiary veins are predominantly alternate and there are 8 to 10 veins per $\mathrm{cm}$ secondary vein. The pattern of the tertiary veins is percurrent, the veins are simple or forked and they are oblique to the midvein. The small teeth are served 
by tertiary veins. The areoles are well developed, they are small and the arrangement is random. Further details are unknown.

Epidermis. (Pl. 12, figs. 1-6; text-figs. 18, 19). The upper epidermis has a thin cuticle and it is composed of 150 to 200 cells per $0.1 \mathrm{~mm}^{2}$. The shape of the cells is isodiametric or slightly elongate and the length is 22 to 32 microns. The arrangement of the cells on the whole is pentagonal or hexagonal and the anticlinal cell wall pattern is straight or rounded. The cell walls are 1 to 3 microns thick and they are pitted. The surface of the cells is striate and the striation is in general parallel to the major venation. The cells over the veins are elongate and they have square or oblique end walls. The cuticle over the veins is coarsely striate. The cells in the leaf margin are elongate, but not arranged in distinct rows. The cell walls are somewhat thickened and the cell surface is coarsely striate. The trichome bases are widely spaced. There are 0 to 10 bases per $0.1 \mathrm{~mm}^{2}$, and they are found both over the veins and in the areoles. The base consists of one thickened cell 12 to 15 microns across. It is surrounded by 5 to 8 radially arranged associated cells of the same size as the rest of the epidermis cells. In the areas around the trichome base the surface striation is directed radially toward the base. The nature of the hairs is unknown.

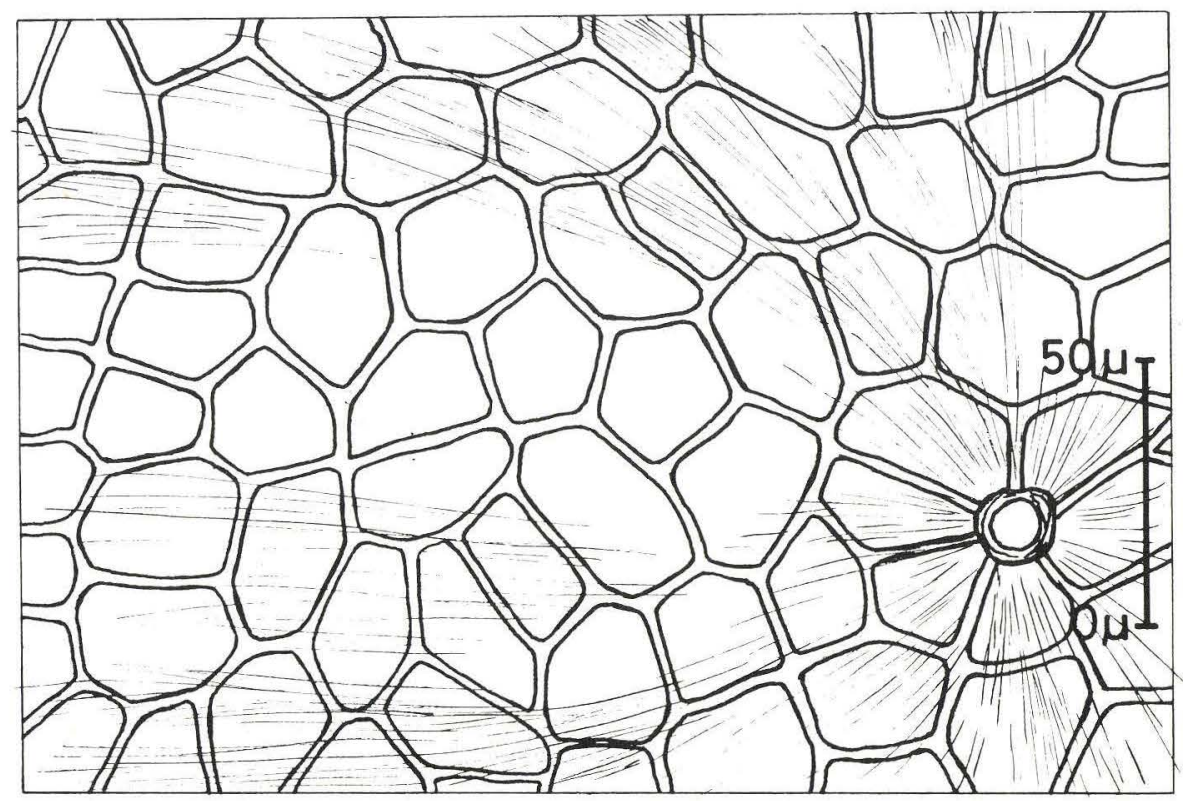

Fig. 18. Salix lavateri A. Braun sensu Hantke 1954. Upper epidermis with striation radiating toward a trichome base. 
A well developed palisade is found below the upper epidermis. The diameter of the palisade cells is 10.5 to 18.5 microns and there are approx. 300 to 450 cells per $0.1 \mathrm{~mm}^{2}$.

The cuticle of the lower epidermis is very thin, and it is composed of 130 to 200 cells per $0.1 \mathrm{~mm}^{2}$. The shape of the cells is isodiametric or slightly elongate and they are 25 to 50 microns long. The arrangement of the cells is pentagonal, and the anticlinal cell wall pattern is straight. The cell walls are 2 to 3 microns thick and they are pitted. There is no special surface ornamentation in the non venous areas of the lower epidermis. The cells over the veins are linear elongate and the end walls are square, oblique or spindle-shaped. The anticlinal cell wall pattern is straight and the walls are unpitted or pitted. The length/width ratio is $1 / 1$ to $4 / 1$ and the surface of the cells is very finely striate. Trichome bases are present in the lower epidermis. They are found both over the veins and between the stomata. They consist of one thickened cell 10 to 13 microns across. The base is surrounded by 6 to 8 radially arranged associated cells. The nature of the hairs is unknown. The cells in the leaf margin are elongate, but not arranged in distinct rows. The cell walls are somewhat thickened and the cell surface is very finely striate. The stomata are variously orientated, un-

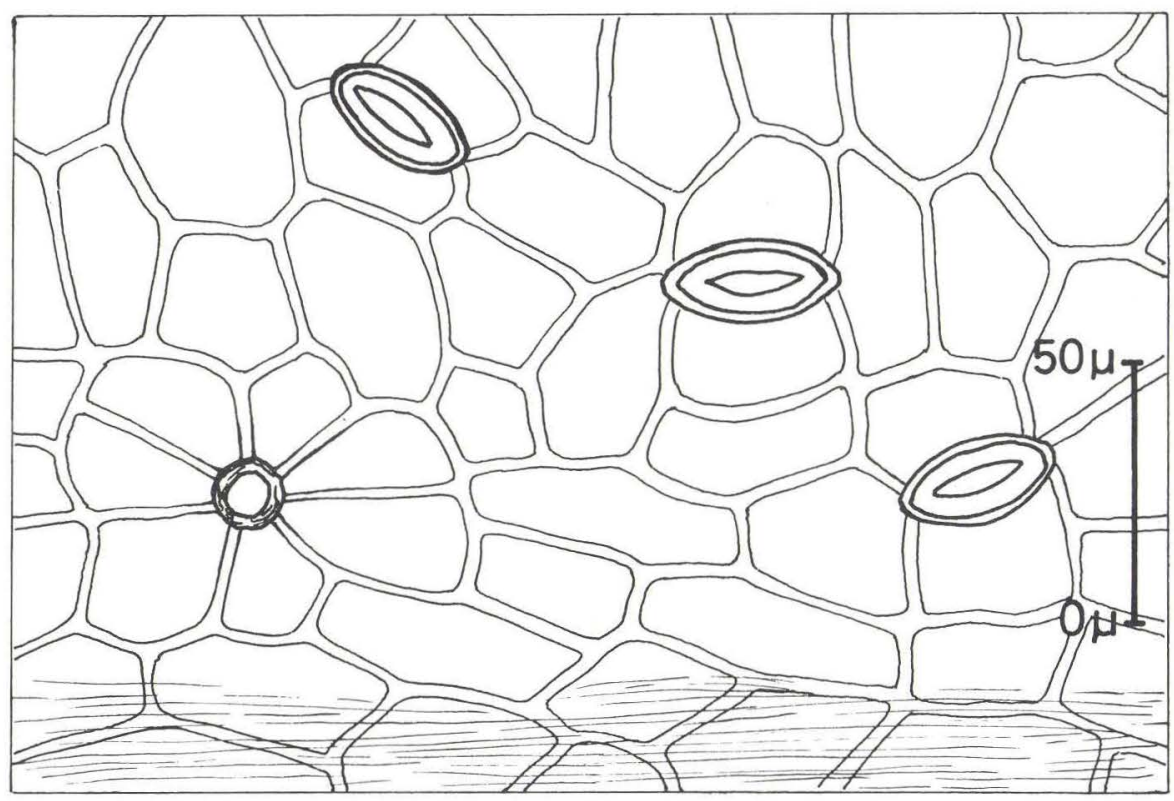

Fig. 19. Salix lavateri A.. Braun sensu Hantke 1954. Lower epidermis with stomata and trichome base. Parallel to the lower edge of the diagram the striation of the leaf margin is seen. 
depressed and more or less equidistant. There are approx. 15 to 30 stomata per $0.1 \mathrm{~mm}^{2}$. They are 21 to 34 microns long, 15 to 22 microns wide and the apices are non-retuse. The stomatal slit is 58 to $72 \%$ of the stomatal length. The stomatal complex is of the brachyparacytic type with the accessory cells not completely enclosing the guard cells. The accessory cells are slightly elongated parallel to the long axis of the guard cells and they are of the same size as the rest of the epidermis cells.

\section{Discussion}

The description on the morphology of Salix lavateri A. Braun sensu Hantke corresponds in all details to the morphology of the Søby leaves. Unfortunately Hantke has not been able to describe the cuticle of his material, so the identification of the Søby leaves is not consolidated by cuticular evidence.

Salix varians Goepp. has long been considered as closely related to $S$. lavateri (Heer 1856, p. 28). But in his work on the Tertiary flora of Silecia, Kräusel (1920, p. 381) includes S. lavateri in S. varians because the difference between the species mentioned by Heer $(1859$, p. 28) is considered worthless.

The cuticle of S. varians has been described by among others Kräusel and Weyland 1954, Bůžek 1971 and Ferguson 1971. The epidermis of S. varians show a high degree of similarity to the epidermis of the Søby leaves, but a marked difference between the species exists in the size of the stomata. The length of the stomata in S. varians is given as 13 to 17 microns (Kräusel et Weyland 1954, p. 125), average 20 microns (Bủžek 1971, p. 68) and 10.8 to 19.8 microns (Ferguson 1971, p. 88). The width given by Ferguson is 5.4 to 10.8 . The length of the stomata in the Søby leaves is 21 to 34 microns and the width is 15 to 22 microns.

11 fragmentary leaves with a particular morphological resemblance to $S$. varians have been selected for a special examination. They are broader than the normal slender type of Salix from the Søby Flora and they have an almost rounded base. 24 cuticle preparations were made on 6 of these specimens. The examination showed no difference from the normal material and the length of the stomata was measured to 24 to 33 microns.

This leads to the conclusion that the Søby Flora only contains one Salix species and that this species has a variation ranging from slender leaves with a decurrent base to broad leaves with an almost rounded base. Further, the Søby species has an epidermis very similar to the epidermis of $S$. varians, but the stomata are much larger. Thus Salix lavateri and $S$. varians must be considered as closely related, but different species. 


\section{Comparison with recent material}

A detailed investigation on the epidermis of the numerous and polymorphic species of recent Salix which frequently hybridize, is considered to be far beyond the level of this work.

Acknowledgements. The present work has been supported by The Danish Natural Science Research Council as a part of the Søby-Fasterholt Browncoal Project. I wish to express my sincere thanks to lektor B. Eske Koch, leader of the Phytopalaeontological Department in Århus, for helpful discussion and suggestions during the work. Conservator S. Bo Andersen has assisted in the laboratory in making Collodium-film preparates and preparations of both fossil and recent cuticles. Mr. John Sommer has prepared the photographs for the plates. The figures have been drawn by Miss J. Lützhöft and the English text has been corrected by lektor C. C. Rokkjar. My thanks are due to all these helpers. The Botanical Museum, University of Copenhagen, and the herbarium of the Botanical Institute, University of Aarhus, have made herbarium material available for comparison. Finally I want to thank Dr. Z. Kvaček (Praha) for sending me information on the epidermis of Ulmus longifolia Unger from Bilin (topotypical specimens). The publishing of this work has been made possible by The Carlsberg Foundation. 


\section{Dansk sammendrag}

Søby Floraen: Fossile planter fra de mellem miocæne delta aflejringer i Søby-Fasterholt området, Midtjylland, Danmark

\section{Indledning}

En ny dansk fossil flora blev i 1969 fundet i et lerlag i toppen af Odderup Formationen (Christensen 1975). I det foreliggende arbejde videref $\varnothing$ res den taxonomiske behandling af Søby Floraen med henblik på at få indhentet oplysninger om det fossile plantesamfund, således at der bliver skabt grundlag for en tolkning af aflejringsmiljø og palæoklima. Forfatteren har i dette arbejde søgt at bringe den anvendte terminologi i overensstemmelse med det standardiserede termsæt, der anbefales af Dilcher (1974).

\section{Systematisk palcoobotanik}

Et stort materiale af Juglandacee småblade af både helrandet og tandet type beskrives. De helrandede småblade henføres til Juglans acuminata Braun. Slægtsbestemmelsen hviler på en grundig unders $\varnothing$ gelse af de fossile blades kutikula og en sammenligning med den recente nærtstående art Juglans regia L. Bestemmelsen af den fossile art bygger udelukkende på morfologiske karakterer. De tandede småblade henf $\varnothing$ res til den fossile art Juglans juglandiformis (Sternb.) Giebel, alene på grundlag af de morfologiske karakterer, idet fossilernes kutikula ikke er bevaret. Slægtsbestemmelsen er baseret på sammenligninger med recent Juglans, men det kan dog ikke helt udelukkes at S $\varnothing$ by fossilerne tilh $\varnothing$ rer slægten Pterocarya. Der er ikke fundet Juglandaceefrugter i Søby Floraen.

Et stort antal velbevarede blade tilhørende slægten Alnus beskrives både morfologisk og anatomisk og bestemmes til Alnus julianaeformis (Sternb.) Kvaček et Holý. Der findes et begrænset antal hunrakler i S $\varnothing$ by Floraen, der ligeledes bestemmes til slægten Alnus, men på grund af den dårlige bevaringstilstand er en artsbestemmelse ikke mulig. De fossile blade er morfologisk sammenlignelige med den recente Alnus japonica Sieb. et Zucc., men der forekommer flere forskelle i epidermisbygningen hos de to arter. 
Der findes en del Castanea blade i S $\varnothing$ by Floraen. Disse blade varierer morfologisk fra typiske Castanea blade til blade med lighed med Quercus kubinyi (Kov.) Berger. En unders $\varnothing$ gelse af de fossile blades kutikula viser imidlertid, at der kun er tale om én art, og denne art påvises at stå meget nær den recente Castanea sativa $\mathrm{L}$.

Et mindre antal håndfligede blade beskrives morfologisk og anatomisk og henføres til Liquidambar europaea A. Braun. Bladene, der både kan være 3- og 5-fligede, sammenlignes med de recente Liquidambar arter, og det påvises, at fossilerne fra S $\varnothing$ by Floraen har meget stor lighed med Liquidambar styraciflua $\mathrm{L}$. både morfologisk og anatomisk.

Et stort antal morfologisk forskelligartede elmeblade beskrives. En detaljeret undersøgelse af de fossile blades kutikula viser, at der på trods af formvariationen kun kan være tale om én art.

Denne art bestemmes til Ulmus pyramidalis Goeppert. Den beskrevne epidermisbygning hos $U$. pyramidalis sammenlignes med en epidermis beskrevet af Ferguson (1971), taxon XV, syn. Ulmus carpinoides Goeppert, og der påpeges flere forskelle $\mathrm{i}$ de to fossilers epidermis. Denne konstatering peger i retning af en løsning på det klassiske problem om, hvorvidt $U$. pyramidalis og $U$. carpinoides skal adskilles eller ikke. Den endelige afklaring bør dog bygge på en unders $\emptyset$ gelse af et langt st $\varnothing$ rre materiale. De fossile elmblade viser en generel morfologisk lighed med en lang række recente elmearter, mens de anatomisk synes at have størst lighed med Ulmus alata Michx.

Til slut beskrives et større antal slanke pileblade med tandet rand. Disse bestemmes på basis af bladenes morfologi til Salix lavateri A. Braun sensu Hantke 1954. Da denne art længe har været regnet for at stå meget nær eller at være identisk med Salix varians Goeppert, sammenlignes de to fossile arters epidermis, og der påvises en markant forskel på størrelsen af de to arters spalteåbninger. Et mindre antal pileblade, der adskiller sig fra S $\varnothing$ by Floraens normale slanke blade, er på basis af epidermisbygningen bestemt til at være en bredbladet variant af Salix lavateri. 


\section{References}

Berger, W. 1952: Die altpliozäne Flora der Congerien-Schichten von Brunn-Vösendorf bei Wien. - Palaeontographica, B, 92, pp. 79-121.

Braun, A. 1845: Die Tertiär-Flora von Öningen. - Neues Jb. Mineral. Geol. Pal., pp. $164-173$.

Buckland, W. 1836: Geology and mineralogy considered with reference to natural theology, I. - 599 pp. London.

Bưžek, Č. 1971: Tertiary Flora from the Northern Part of the Pextipsy Area (NorthBohemian Basin). - Rozpr. Ustř. geol. 36, pp. 1-118.

Christensen, E. F. 1975: The Søby Flora: Fossil plants from the Middle Miocene delta deposits of the Søby-Fasterholt area, Central Jutland, Denmark. - Danm. geol. Unders. II. række, 103, pp. 1-41.

Czeczott, H. 1934: What is Fagus Feroniae Unger. - Acta Soc. Bot. Pol. 11, pp. $109-116$.

Dilcher, D. L. 1974: Approaches to the Identification of Angiosperm Leaf Remains. Bot. Rev. 40(1), 157 pp.

Engelhardt, H. 1885: Die Tertiärflora des Jesuitengrabens bei Kundraditz in Nordböhmen. - Novo Acta Leop.-Carol. Deutsch. Akad. Naturf. 48(3), pp. 299-408.

Engelhardt, H. 1903: Über Tertiärpflanzen von Himmelsberg bei Fulda. - Abh. Senckenb. Naturf. Ges. 20. pp. 251-305.

Ettingshausen, C. 1866: Die fossile Flora des Tertiärbeckens von Bilin. I. - Denkschr. Akad. Wiss. math.-naturw. K1. 26, pp. 1-98.

Ettingshausen, C. 1869: Die fossile Flora des Tertiärbeckens von Bilin. III. - Denkschr. Akad. Wiss. math.-naturw. K1. 29, pp. 1-110.

Ettingshausen, C. 1872: Uber Castanea vesca und ihre vorweltliche Stammart. - Sber. math.-naturw. Cl. Akad. Wiss., 44(1-5), pp. 147-164.

Ettingshausen, C. 1888: Die fossile Flora von Leoben in Steiermark. I-II. - Denkschr. Akad. Wiss. math.-naturw. K1. 54, pp. 260-384.

Ferguson, D. K. 1971: The Miocene flora of Kreuzau, Western Germany. I. The leafremains. - 297 pp. Amsterdam, London.

Giebel, C. G. 1852: Deutschlands Petrefacten. Leipzig.

Goeppert, H. R. 1855: Die tertiäre Flora von Schossnitz in Schlesien. - Pp. 1-51, Görlitz.

Hantke, R. 1954: Die fossile Flora der obermiozänen Oehninger-Fundstelle Schrotzburg. - Denkschr. schweiz. naturf. Ges., 80(2), pp. 27-118.

Heer, O. 1856: Die tertiäre Flora der Schweiz. 2. - Winterthur.

Heer, O. 1859: Die tertiäre Flora der Schweiz. 3. - Winterthur.

Herr, O. 1875: Ueber die miocenen Kastanien-Bäume. - Verh. geol. Reichanst. 6, pp. 93-95.

Jähnischen, H. 1956: Über Castanopsis furcinervis (Rossm.) Kr. u. Wld. (Fagacee) aus 
der alttertiären Braunkohle der Ukraine. - Jb. Staatl. Mus. Min. Geo. II, pp. $142-147$.

Jung, W. 1963: Blatt- und Fruchtreste aus der oberen Süsswassermolasse von Massenhausen, Kreis Freising (Oberbayern). - Palaeontographica, B, 112, pp. 119-166.

Kilpper, K. 1971: Neue Pflanzenfossilien aus dem niederrheinischen Tertiär. - N. Jb. Geol. Paläont. Mh. 1971 (6), pp. 348-355.

Kirchheimer, F. 1957: Die Laubgewächse der Braunkohlenzeit. - 783 pp. Halle (Saale).

Knobloch, E. 1969: Tertiäre Floren von Mähren. - 201 pp. Brno.

Koch, B. E. \& Friedrich, W. L. 1970: Geologisch-Paläobotanische Untersuchung der miozänen Braunkohlen bei Fasterholt in Jütland, Dänemark. - Bull. geol. Soc. Dänemark, 20 (2), pp. 169-191.

Koch, B. E., Friedrich, W. L., Christensen, E. F. \& Friis, E. M. 1973: Den Miocæne brunkulsflora og dens geologiske miljø i S $\varnothing$ by-Fasterholt området sydøst for Herning. - Dansk geol. Foren., Årsskrift for 1972, pp. 1-57.

Kovats, J. 1856: Fossile Flora von Erdöbénye. - Arb. Geol. Ges. Ung., I, pp. 1-37.

Kräusel, R. 1919: Die Pflanzen des schlesischen Tertiärs. - Jb. preuss. geol. Landesanst. $38(1-2)$, pp. $1-338$.

Kräusel, R. 1920: Nachträge zur Tertiärflora Schlesiens. III. Über einige Originale Goepperts und neuere Funde. - Jb. preuss. geol. Landesanst. 40(3), pp. 363-433.

Kräusel, R. \& Weyland, H. 1950: Kritische Untersuchungen zur Kutikularanalyse tertiärer Blätter. I. - Palaeontographica, B, 91, pp. 7-92.

Kräusel, R. \& Weyland, H. 1954: Kritische Untersuchungen zur Kutikularanalyse tertiärer Blätter. II. - Palaeontographica, B, 96, pp. 106-163.

Kvaček, Z. \& Holý, F. 1974: Alnus julianaeformis (Sternberg 1823) comb. n., a noteworthy Neogene alder. - Čas. Mineral. Geol. 19(4), pp. 367-372.

LaMotte, R. S. 1944: Supplement to Catalogue of Mesozoic and Cenozoic plants of North America. - Geol. Surv. Bull. 924, pp. 1-330.

Ludwig, R. 1859-61: Fossile Pflanzen aus der ältesten Abteilung der Rheinisch-Wetterauer Tertiärformation. - Palaeontographica 8, pp. 39-154.

Mädler, K. 1939: Die pliozäne Flora von Frankfurt am Main. - Abh. senckenberg. naturf. Ges. 446, pp. 1-202.

Mai, D. H. 1963: Beiträge zur Kenntnis der Tertiärflora von Seifhennersdorf (Sachsen). - Jb. Staatl. Mus. Mineral. Geol. Dresden, 1963, pp. 39-114.

Mathiesen, F. J. 1975: Palaeobotanical Investigations into some Cormophytic Macrofossils from the Neogene Tertiary Lignites of Central Jutland. III: Angiosperms. K. danske Vidensk. Selsk. Biol. Skr. 20(9), pp. 1-59.

Menzel, P. 1906: Über die Flora der Senftenberger Braunkohlenablagerungen. - Abh. königl. preuss. geol. Landesanst. Bergakad. N. F. 46, pp. 1-176.

Nagel, K. 1915: Juglandaceae - Foss. Cat. II, 6, pp. 1-87.

Sternberg, K. v. 1823: Versuch einer geognostisch-botanischen Darstellung der Flora der Vorwelt. I(3). - Pp. 1-39, Leipzig, Pragh.

Sternberg, K. v. 1825: Versuch einer geognostisch-botanischen Darstellung der Flora der Vorwelt. I(4). - Pp. 1-48, Leipzig, Pragh.

Stizenberger, E. 1851: Übersicht der Versteinerungen des Grossherzogthums Baden. - Pp. 1-144. Freiburg.

Stur, D. 1867: Beiträge zur Kenntnis der Flora der Süsswasserquarze, der Congerienund Cerithienschichten im Wiener und Ungarischen Becken. - Jb. geol. Reichanst., 17 , pp. $77-188$.

Unger, F. 1845: Chloris protogaea. Beiträge zur Flora der Vorwelt. - 6-7, pp. 25-110. 
Unger, F. 1847: Chloris protogaea. Beiträge zur Flora der Vorwelt. - 8-10, pp. 93-149. Unger, F. 1849: Blätterabdrücke aus dem Schwefelflötze von Swoszowice in Galizien. - Haiding, naturw. Abh., 3 (1), pp. 121-128.

Unger, F. 1850: Genera et Species Plantarum Fossilium. - Vindobonae.

Unger, F. 1851: Die fossile Flora von Sotzka. - Denkschr. Akad. Wiss., math.-naturw. K1. 2, pp. 130-197.

Unger, F. 1854: Die fossile Flora von Gleichenberg. - Denkschr. Akad. Wiss., math.naturw. K1. 7, pp. 1-28.

Unger, F. 1861: Sylloge plantarum fossilium. I. - Denkschr. Akad. Wiss., math.-naturw. K1. 19, pp. 1-48.

Walther, H. 1964: Paläobotanische Untersuchungen im Tertiär von Siefhennersdorf. Jb. Staatl. Mus. Mineral. Geol. Dresden 1964, pp. 1-131. 
Plates

4* D.G.U. II. rk. nr. 108 
Plate 1

Juglans acuminata Braun

Figs. 1-6. Leaves (leaflets), all prepared after the collodium-film method, $\times 1$.

Photo: J. Sommer 


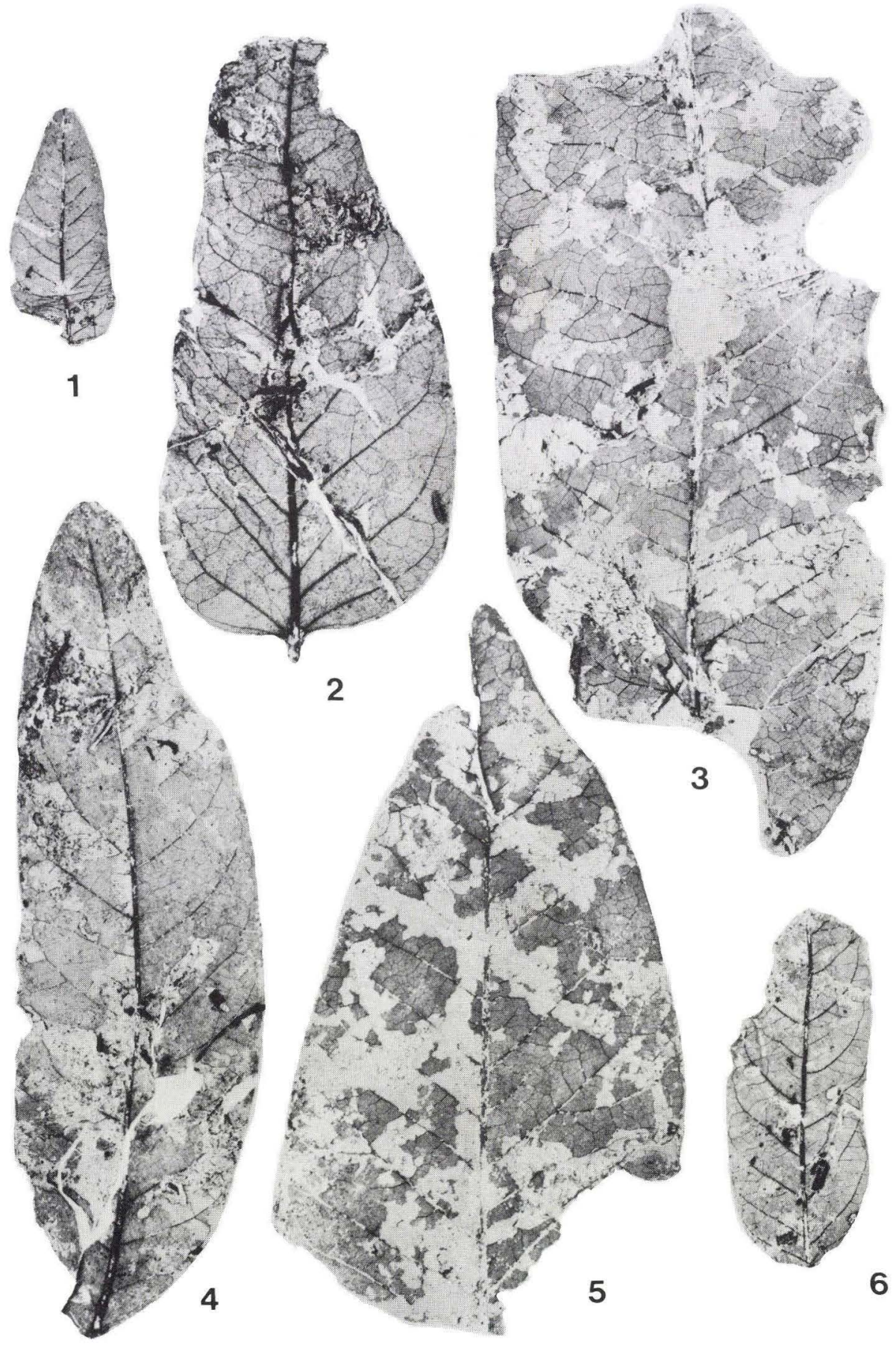


Plate 2

\section{Juglans acuminata Braun}

Fig. 2 Upper epidermis with trichome base in the upper left corner.

Fig. 4. Lower epidermis, the stomata are not visible.

Fig. 5. Lower epidermis with a stomata in the upper part of the photograph and a trichome base in the lower part.

Fig. 6. Lower epidermis showing trichome bases with attached hair fragments over a vein.

Juglans regia L.

Fig. 1. Upper epidermis.

Fig. 3. Lower epidermis with stomata.

All pictures photographed with differential-interference contrast after Nomarski (Photomicroscope II, Zeiss). 


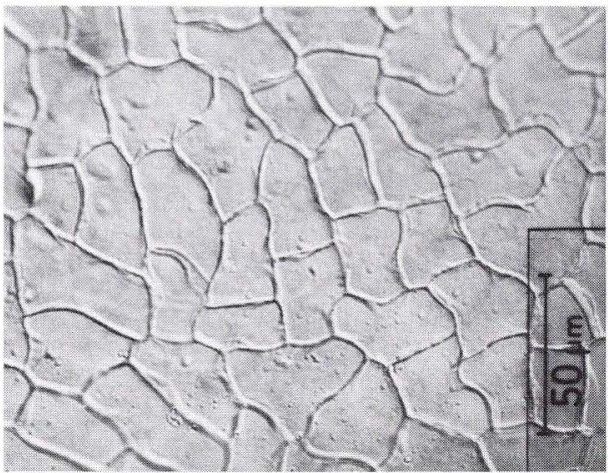

1

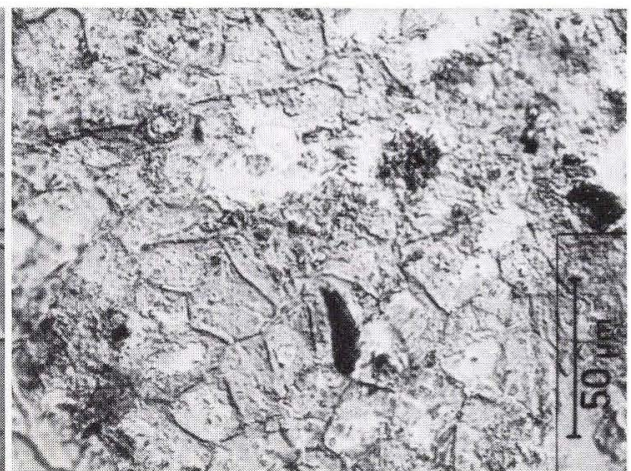

2

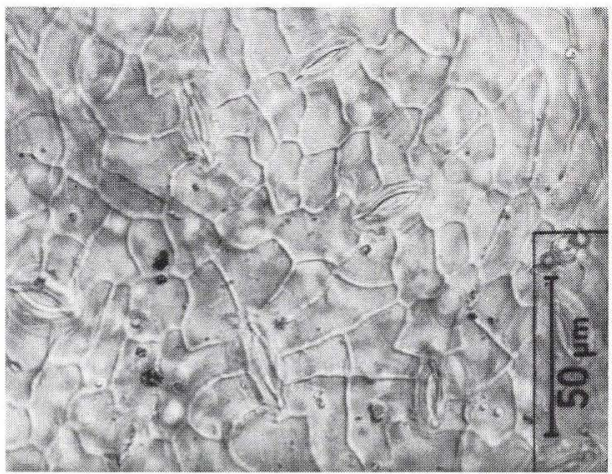

3

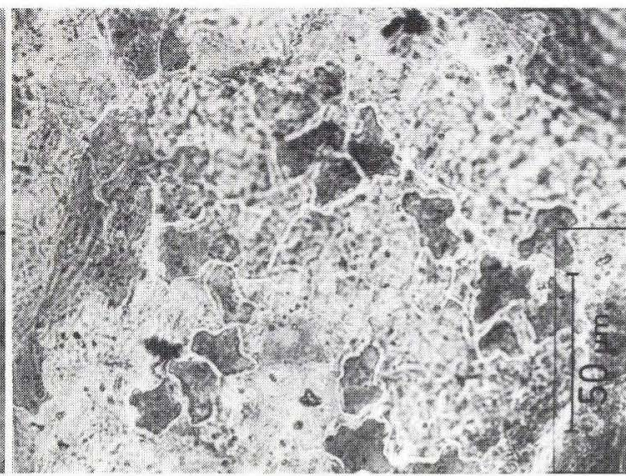

4
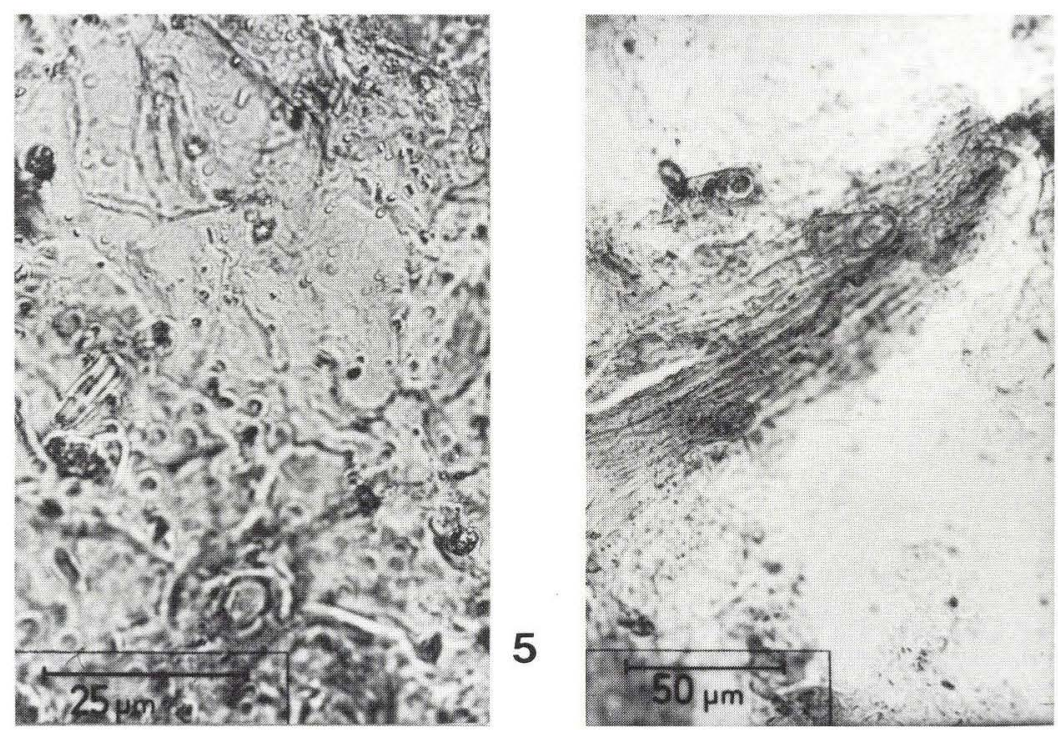
Plate 3

Juglans juglandiformis (Sternb.) Giebel

Figs. 1-8. Leaflet's, all prepared after the collodium-film method, $\times 1$.

Photo: J. Sommer 
D.G.U.II.rk.nr. 108
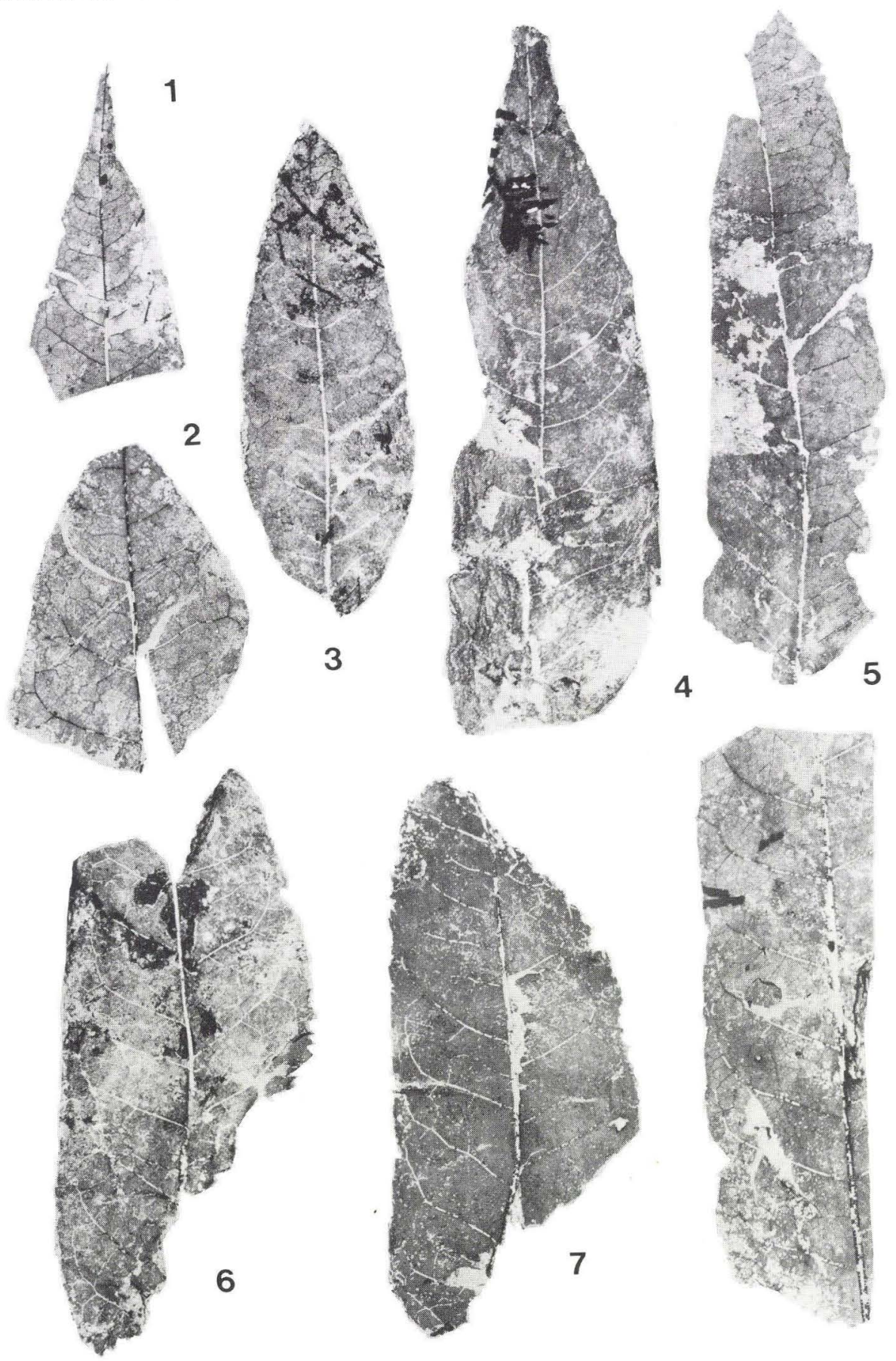

8 
Plate 4

Alnus julianaeformis (Sternb.) Kvaček et Holý

Figs. 1-8. Leaves, all prepared after the collodium-film method, $\times 1$.

Figs. 9-10. Female catkins, $\times 1$.

Photo: J. Sommer 

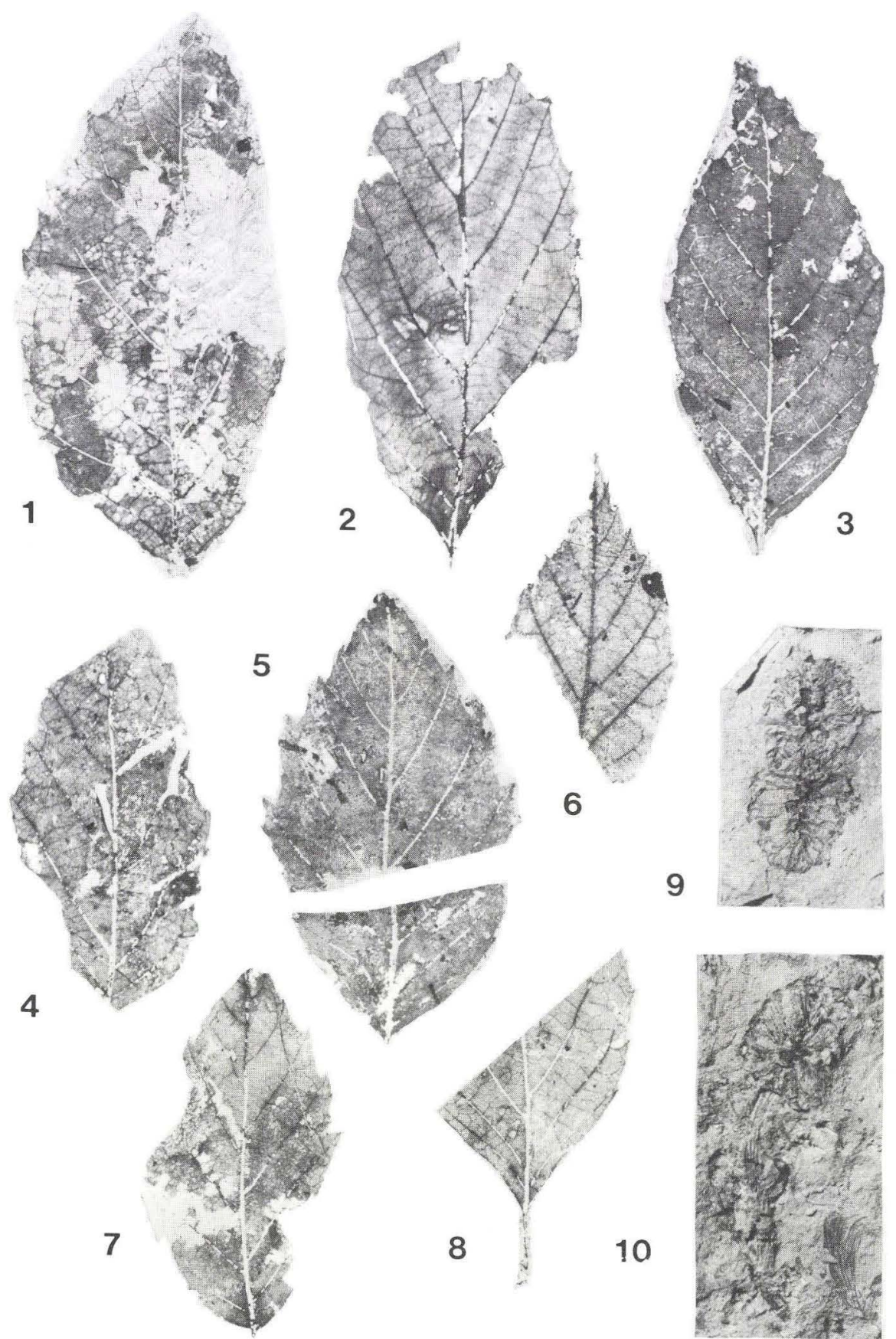
Plate 5

\section{Alnus julianaeformis (Sternb.) Kvaček et Holý}

Fig. 2. Upper epidermis with a (dark) 4-celled trichome base over vein.

Fig. 4. Lower epidermis with a stomata in the centre of the picture.

Fig. 5. Simple hair in the lower epidermis.

Fig. 6. Lower epidermis with a large number of simple hairs in a corner between the midvein and a secondary vein.

Alnus japonica Sieb. et Zucc.

Fig. 1. Upper epidermis with a 4-celled trichome base. Palisade cells are seen to the left.

Fig. 3. Lower epidermis with stomata and a 4-celled trichome base.

All pictures photographed with differential-interference contrast after Nomarski. (Photomicroscope II, Zeiss). 


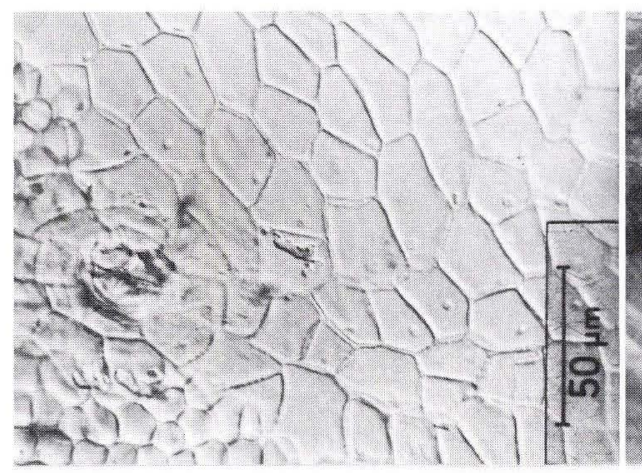

1

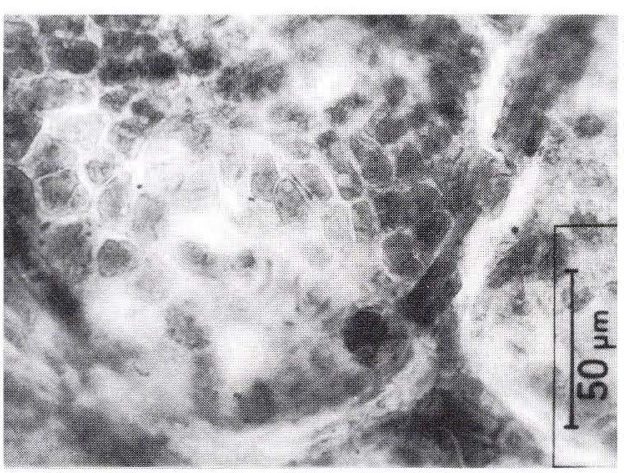

2
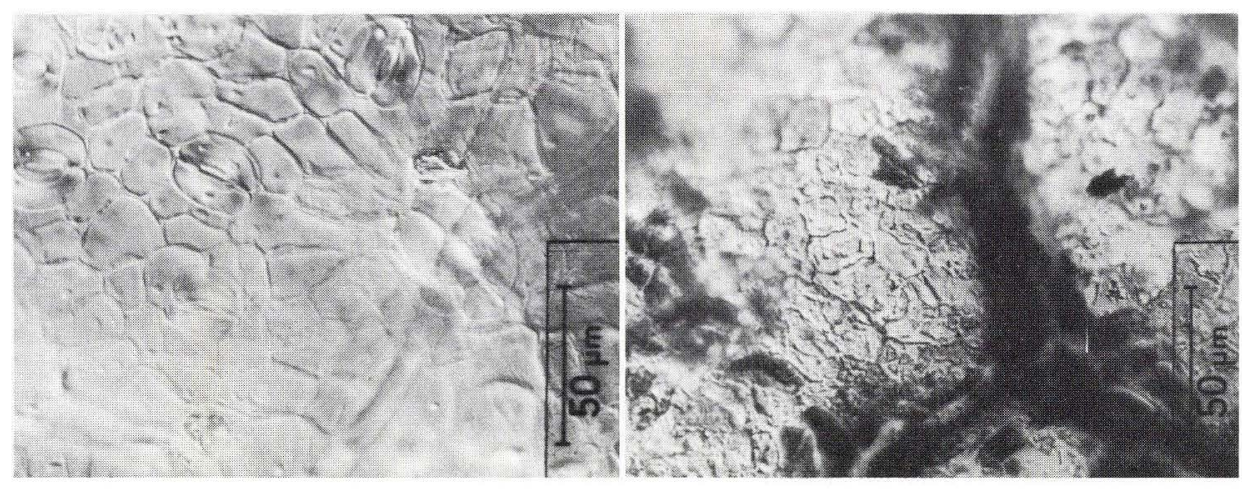

3

4

5

6

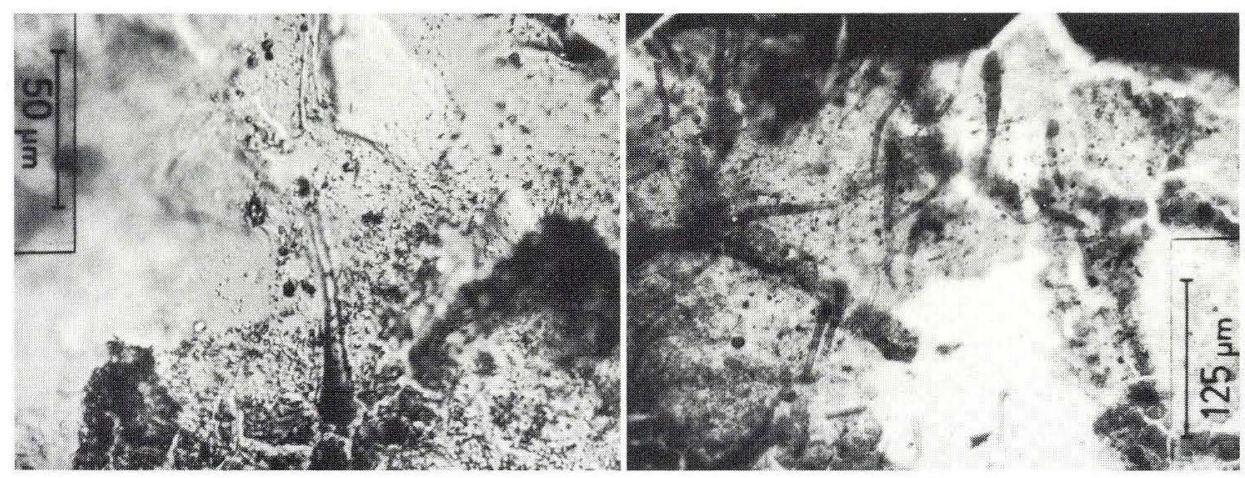

5 D.G.U. II. rk. nr. 108 
Plate 6

Castanea atavia Unger

Figs. 1-5. Unprepared leaves showing variation in morphology, $\times 1$.

Fig. 5. Juvenile leaf, $\times 1$.

Photo: J. Sommer 

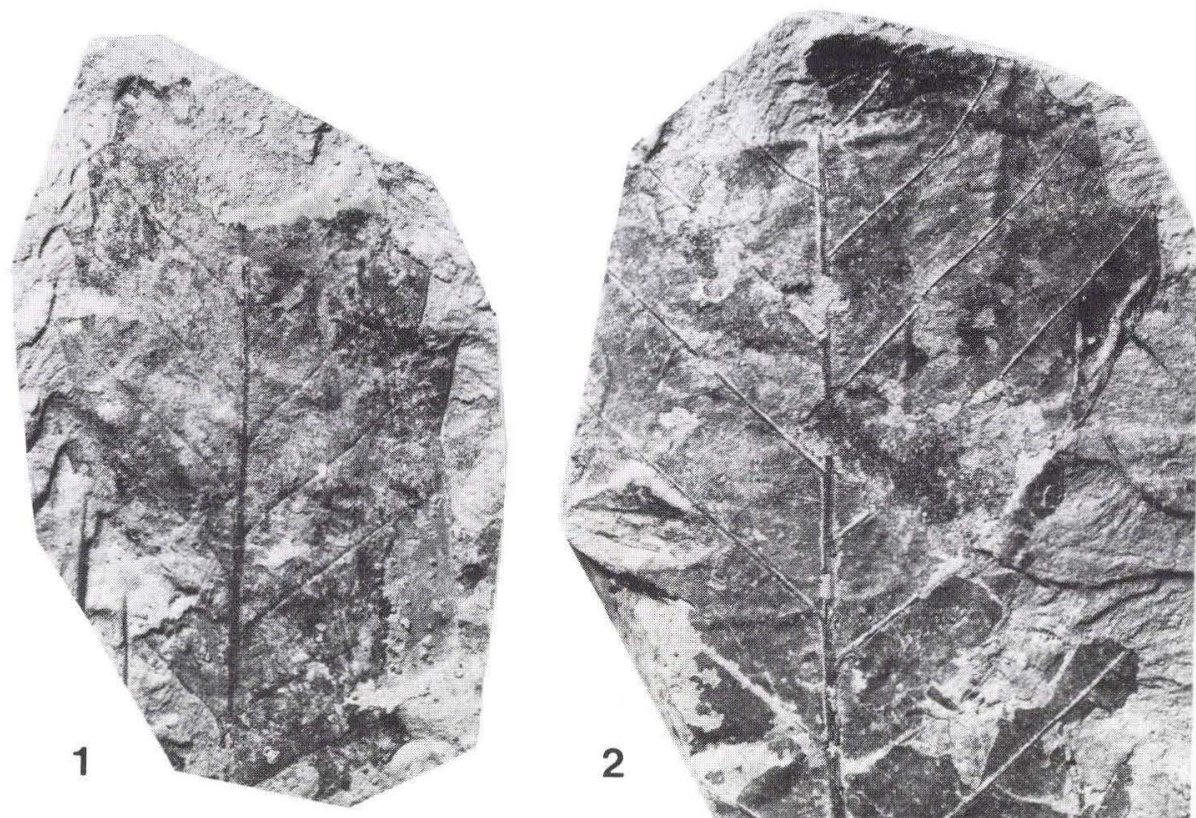

.

in.

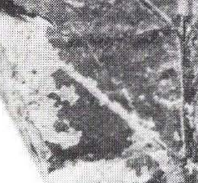

2
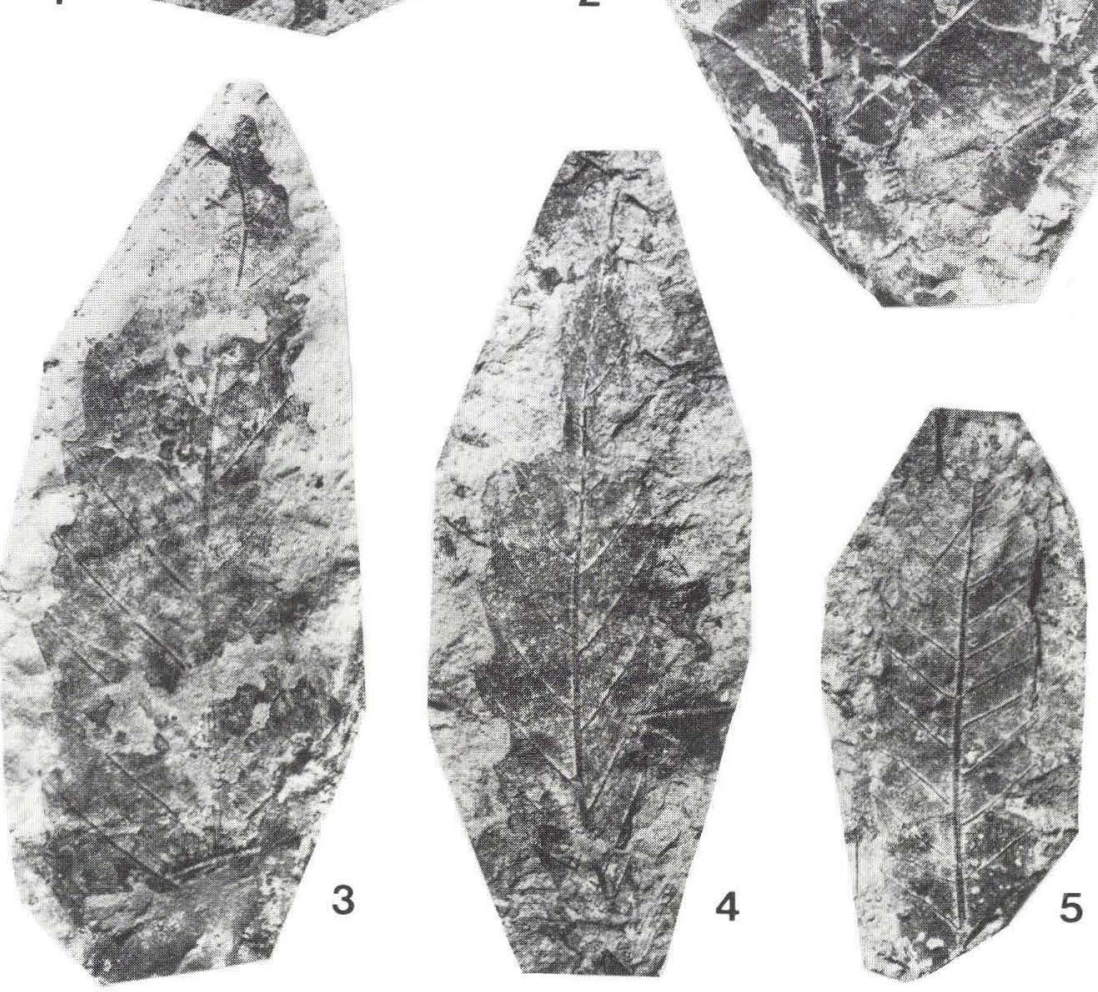
Plate 7

\section{Castanea atavia Unger}

Fig. 2. Upper epidermis.

Fig. 4. Lower epidermis with stomata and trichome bases.

Fig. 6. Lower epidermis with simple and branched hairs. A vein is seen parallel to the lower edge of the picture.

\section{Castanea sativa $\mathrm{L}$.}

Fig. 1. Upper epidermis.

Fig. 3. Lower epidermis with stomata and trichome bases.

Fig. 5. S. E. M. picture showing simple and branched hairs in the lower epidermis.

S. E. M. photo S. R. Jacobsen. All other pictures photographed with differential-interference contrast after Nomarski (Photomicroscope II, Zeiss). 


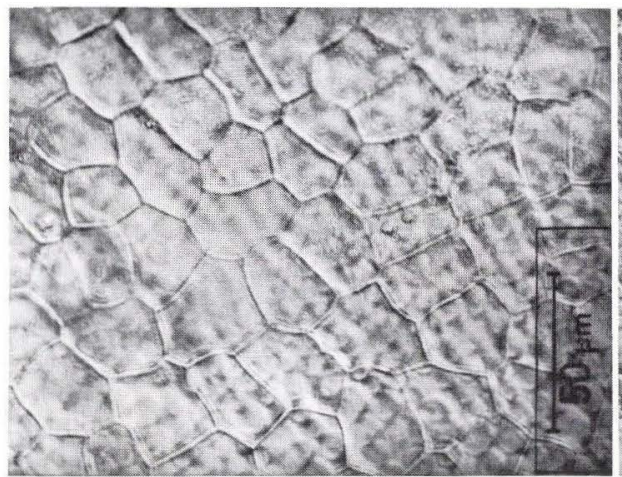

1

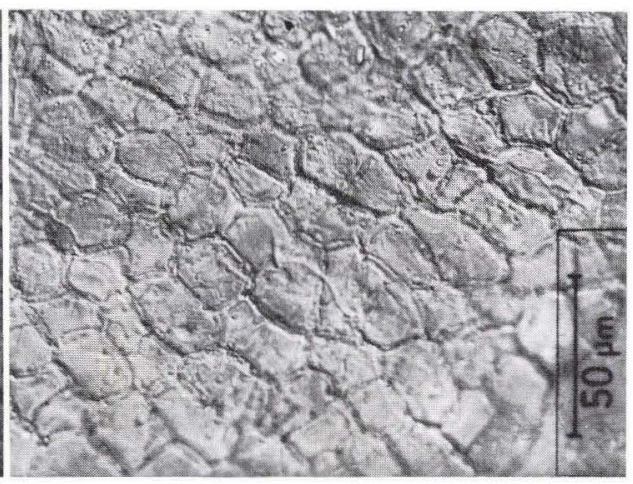

2

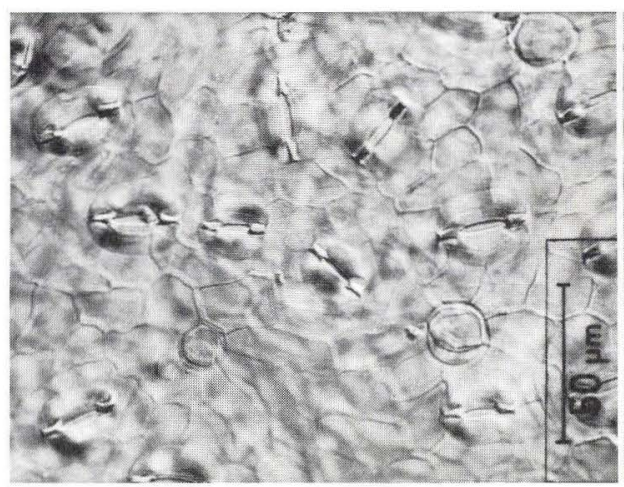

3

5

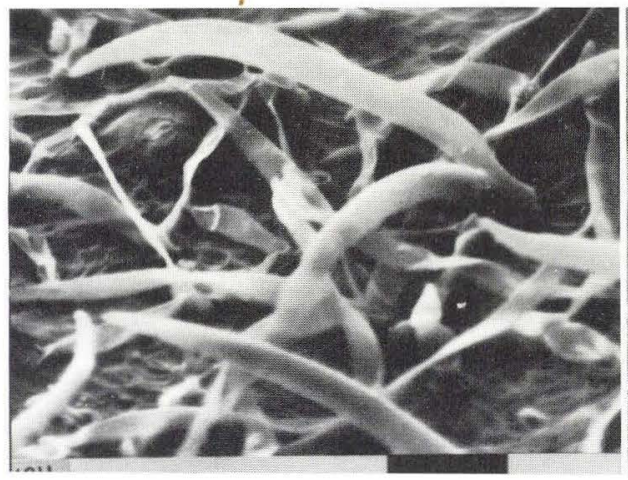

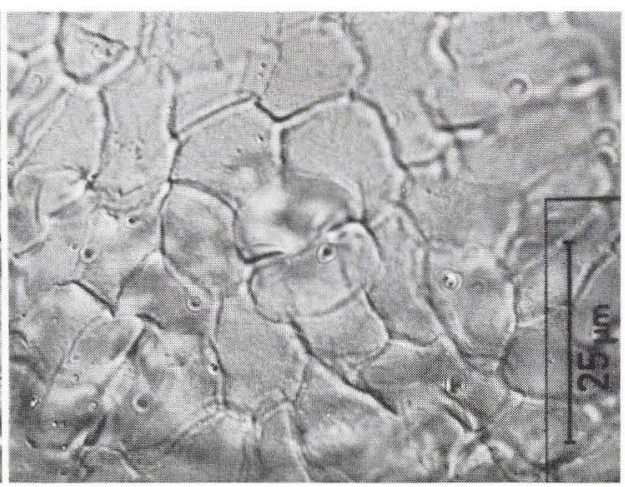

4

6

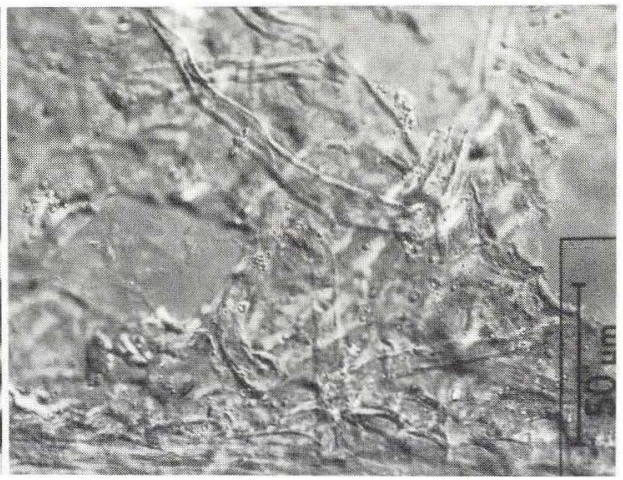


Plate 8

Liquidambar europaea A. Braun

Fig. 2. Upper epidermis.

Fig. 4. Lower epidermis with stomata.

Fig. 5. Upper epidermis in leaf margin.

Fig. 6. Lower epidermis in leaf margin.

Liquidambar styraciflua L.

Fig. 1. Upper epidermis.

Fig. 3. Lower epidermis with stomata.

All pictures photographed with differential-interference contrast after Nomarski (Photomicroscope II, Zeiss). 


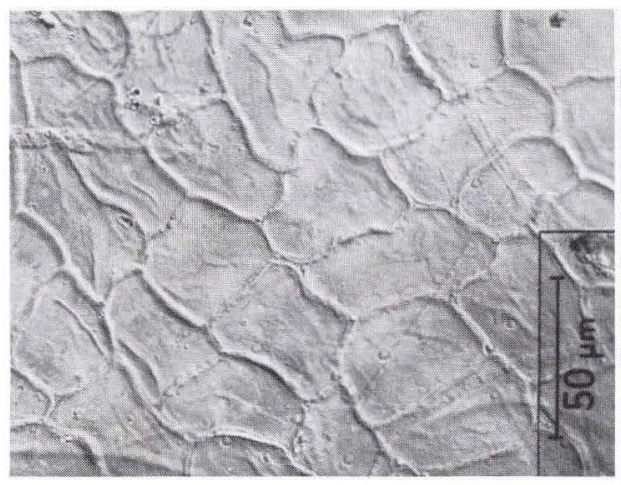

1

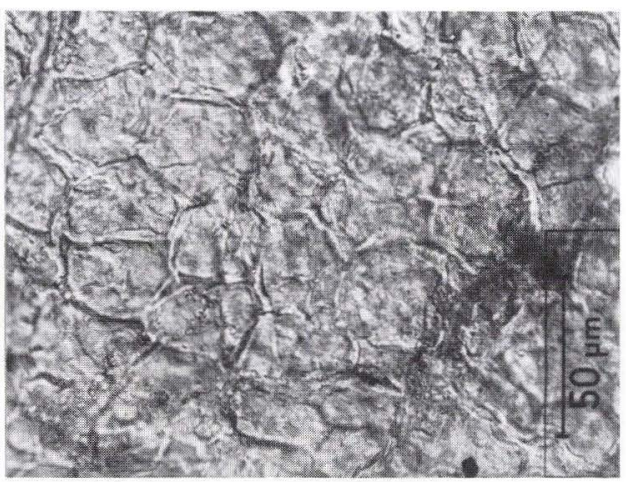

2

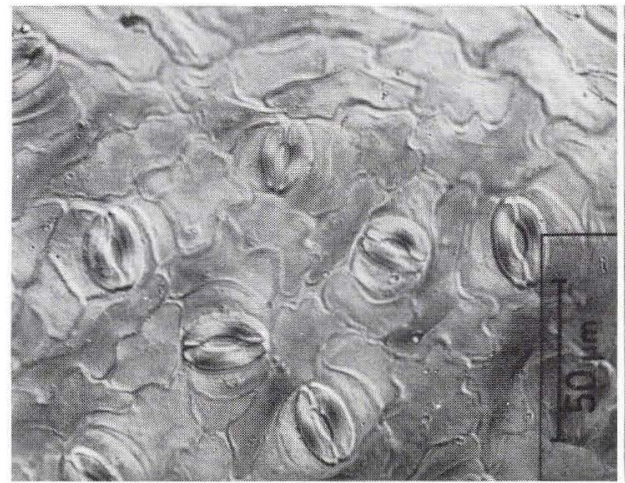

3

5

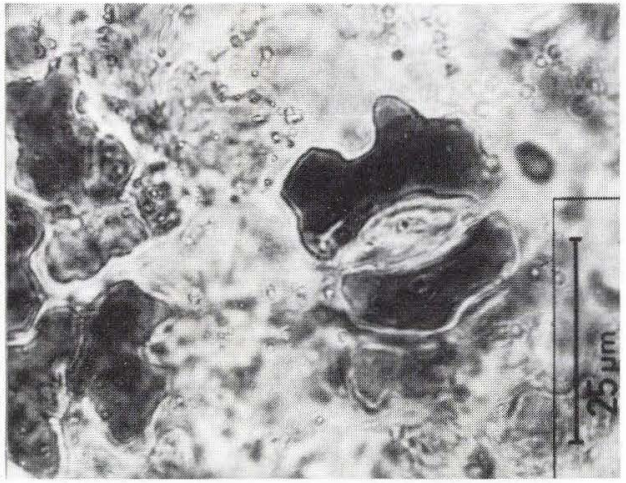

4

6
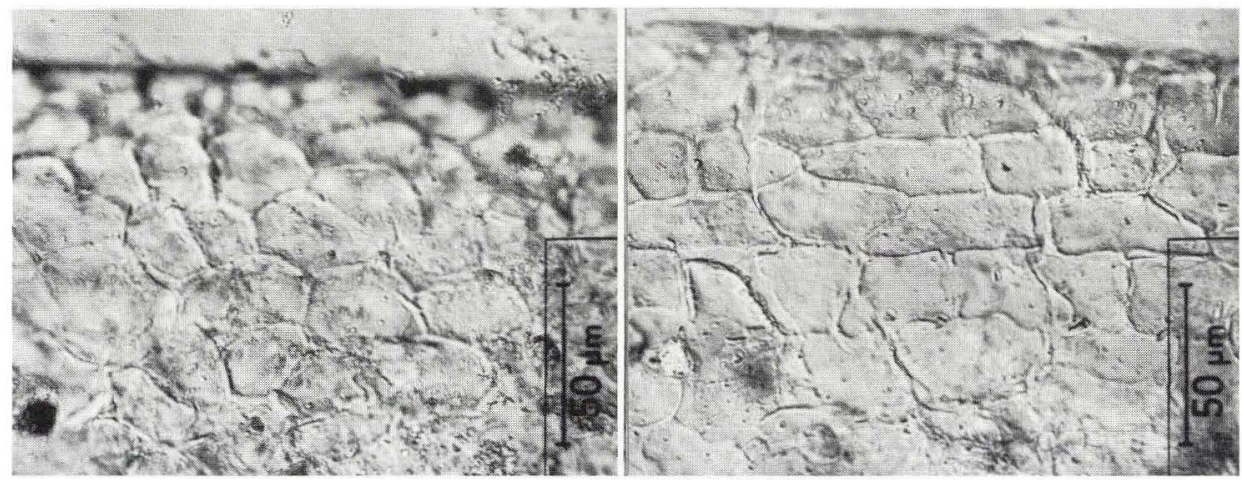
Plate 9

\section{Ulmus pyramidalis Goeppert}

Figs. 1-10. Leaves showing the broad morphological variation, $\times 1$.

Fig. 1. Larger leaf with atypical base, $\times 1$.

Figs. 2, 3. The normal and most abundant leaf type, $\times 1$.

Fig. 4. Branching of the secondary veins, $\times 1$.

Fig. 5. Well developed leaf apex, $\times 1$.

Fig. 6. Smaller leaf showing simple teeth near leaf apex, $\times 1$.

Figs. 7-9. The broad leaf type, not as common as the leaves in figs. 2 ang $3, \times 1$.

Fig. 10. Minute leaf, very rare, $\times 1$.

Photo: J. Sommer 

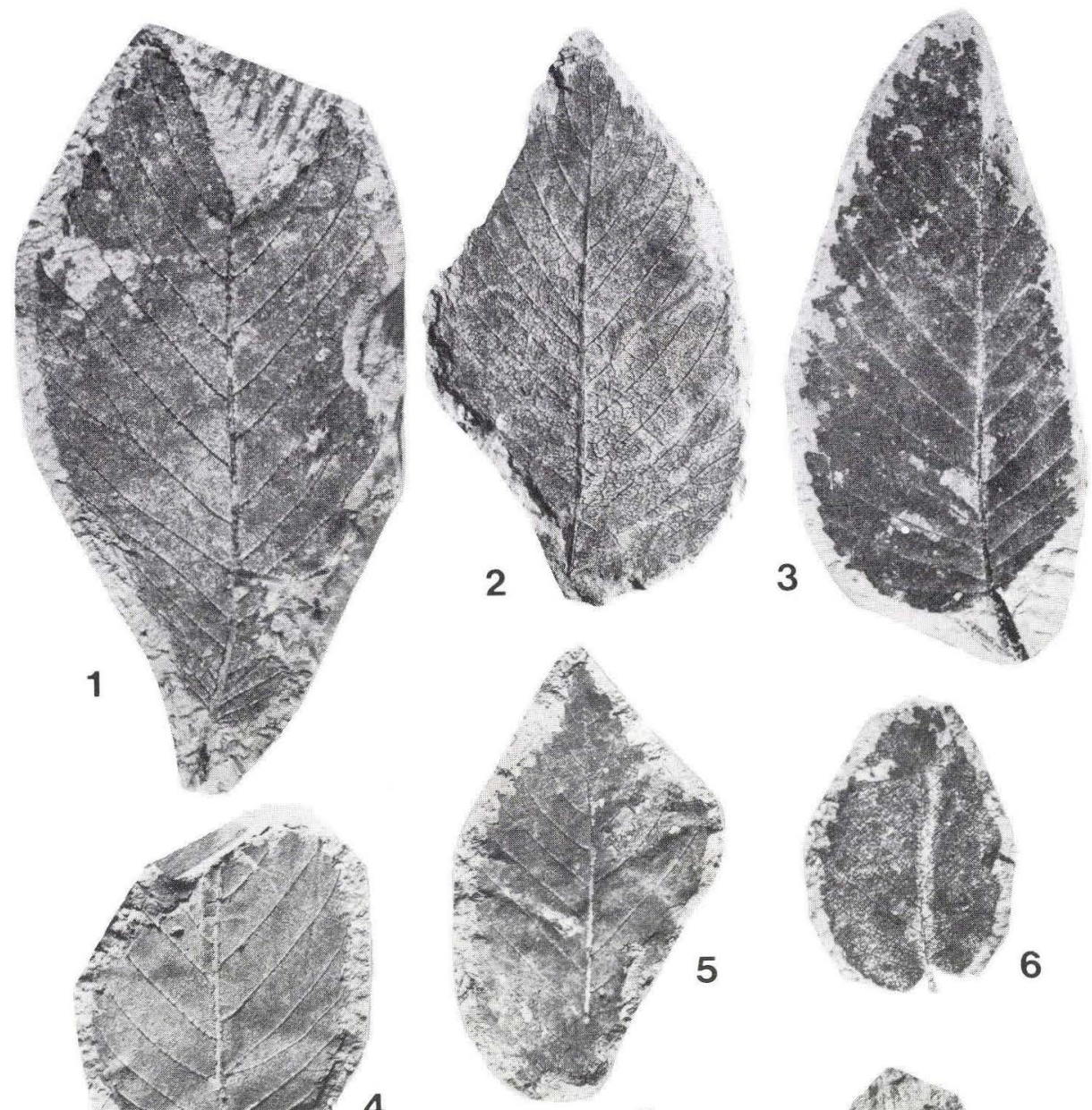

4
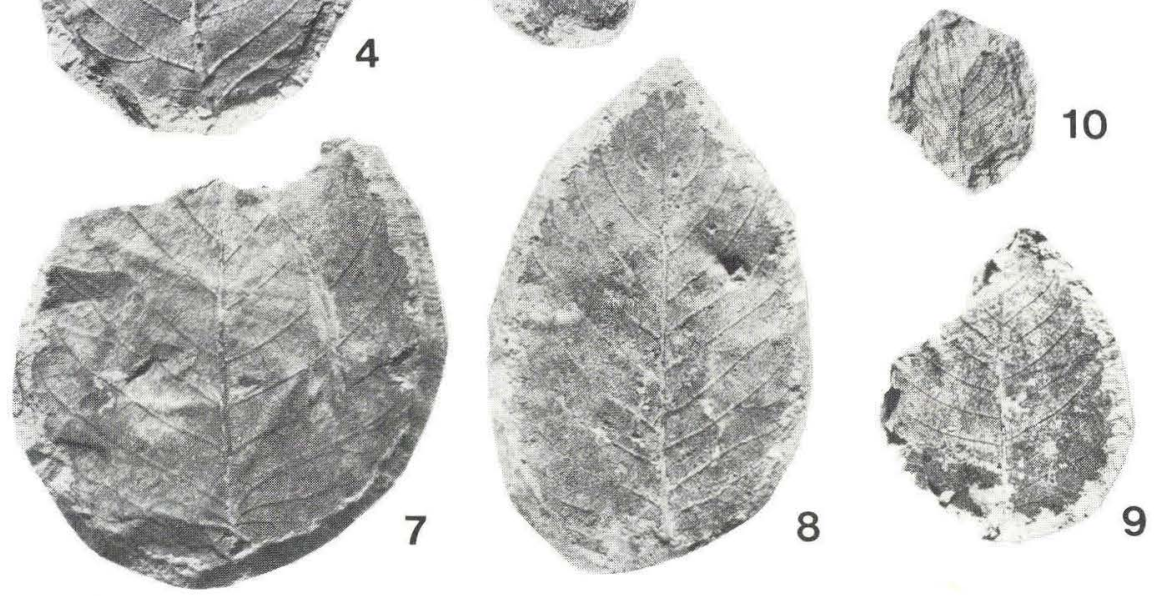
Plate 10

\section{Ulmus pyramidalis Goeppert}

Fig. 2. Upper epidermis in non venous area.

Fig. 4. Lower epidermis showing the openings between the accessory cells where the stomata have been placed. In the lower right corner of the picture a trichome base is seen.

Fig. 5. Simple hairs in the lower epidermis.

Fig. 6. Palisade cells below the upper epidermis.

\section{Ulmus alata Michx.}

Fig. 1. Upper epidermis.

Fig. 3. Lower epidermis showing stomata and trichome base over a vein.

All pictures photographed with differential-interference contrast after Nomarski (Photomicroscope II, Zeiss). 

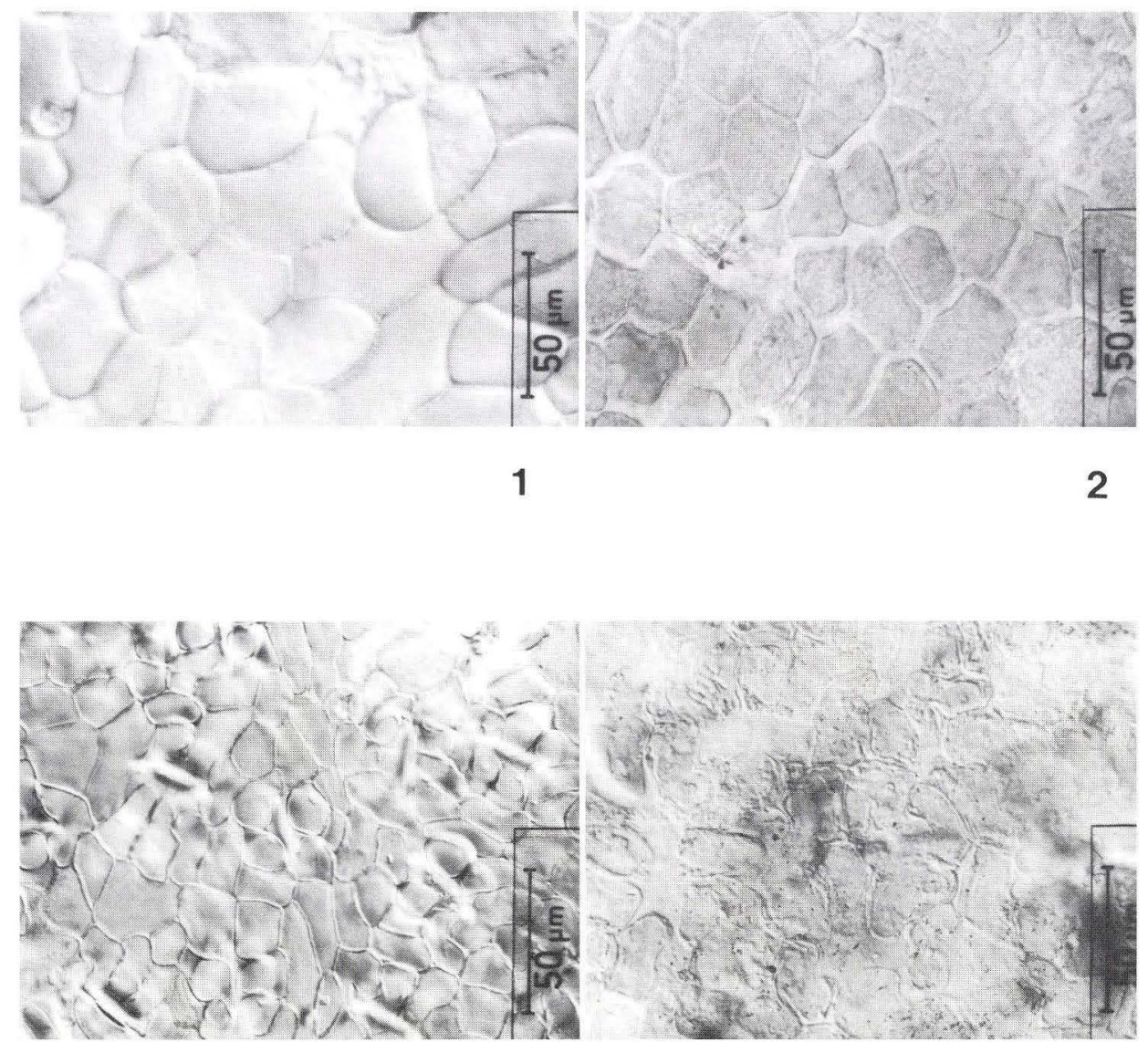

3

5

6
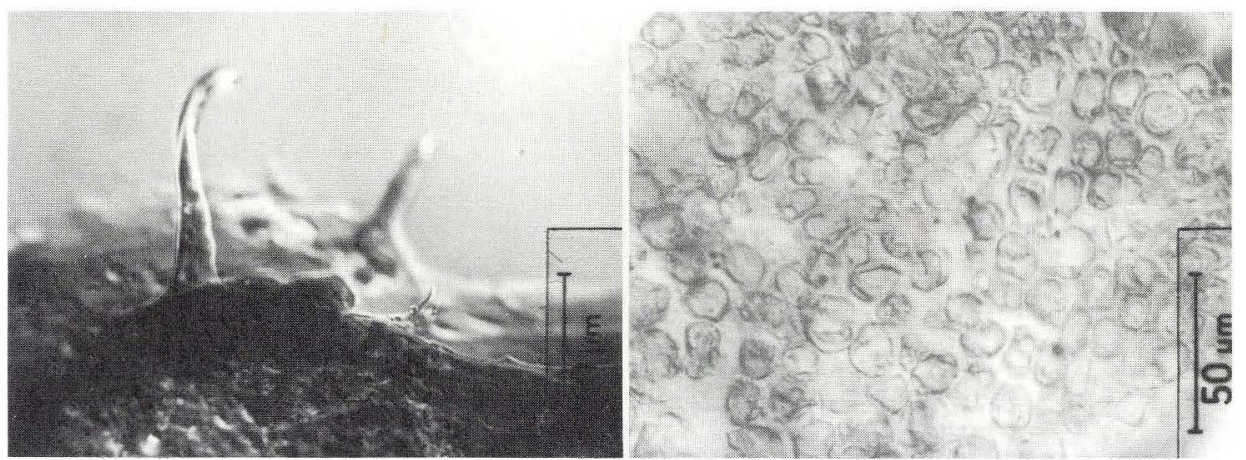
Plate 11

Salix lavateri A. Braun sensu Hantke 1954.

Fig. 1-12. Fragmentary leaves showing variation in morphology, $\times 1$.

Fig. 11, 12. Fragments of large leaves with almost rounded bases, $\times 1$.

All the leaves are prepared after the collodium-film method.

Photo: J. Sommer 

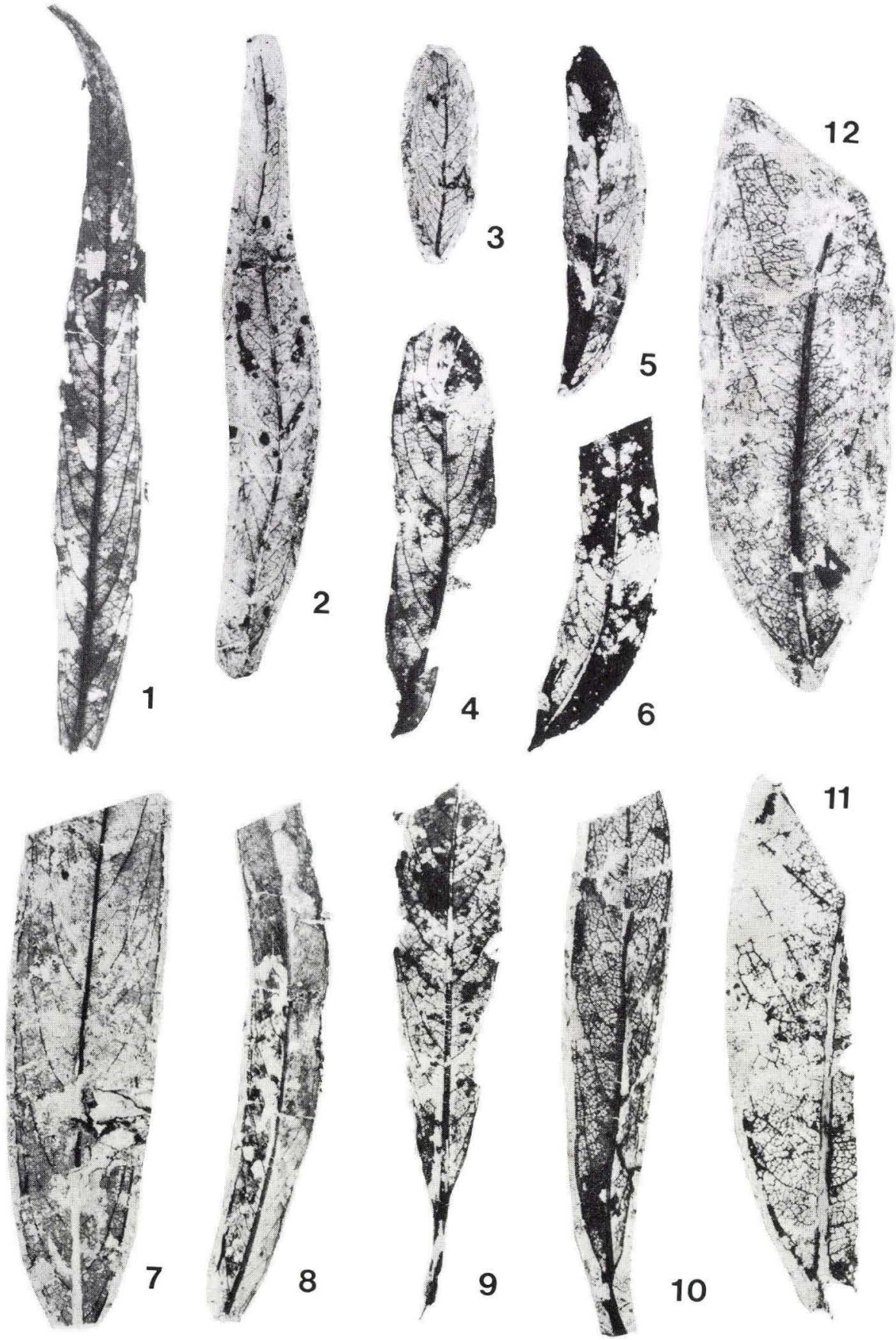
Plate 12

Salix lavateri A. Braun sensu Hantke 1954

Fig. 1. Upper epidermis .

Fig. 2. Lower epidermis with stomata and trichome base. Cell walls are clearly pitted.

Fig. 3. Palisade cells below upper epidermis.

Fig. 4. Arrangement of stomata.

Fig. 5. Upper epidermis over midvein.

Fig. 6. Lower epidermis with trichome bases over midvein.

All pictures photographed with differential-interference contrast after Nomarski (Photomicroscope II, Zeiss). 


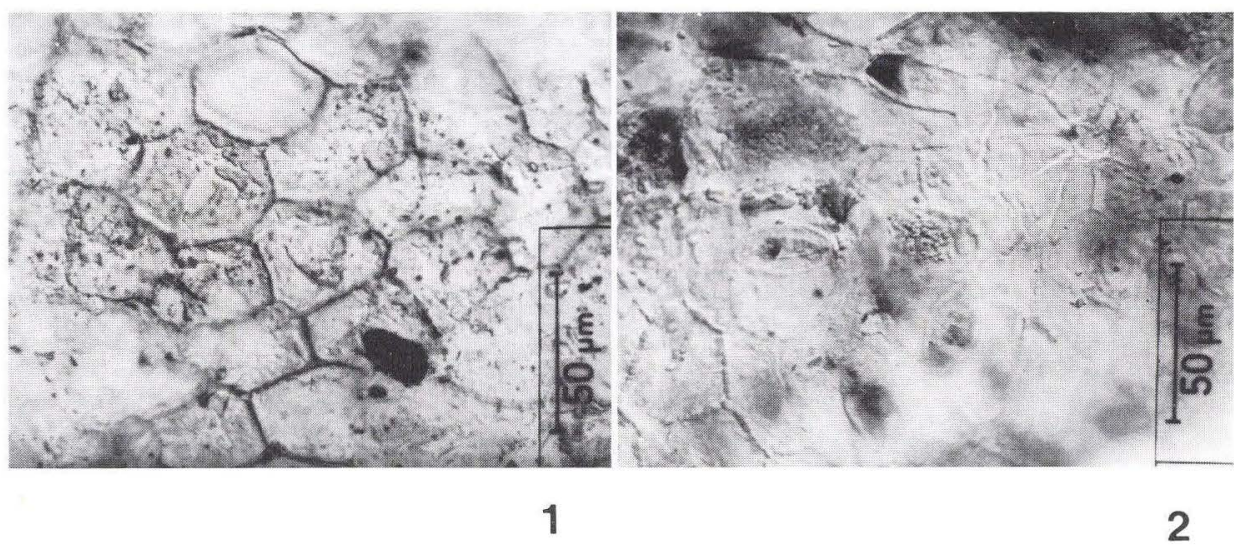

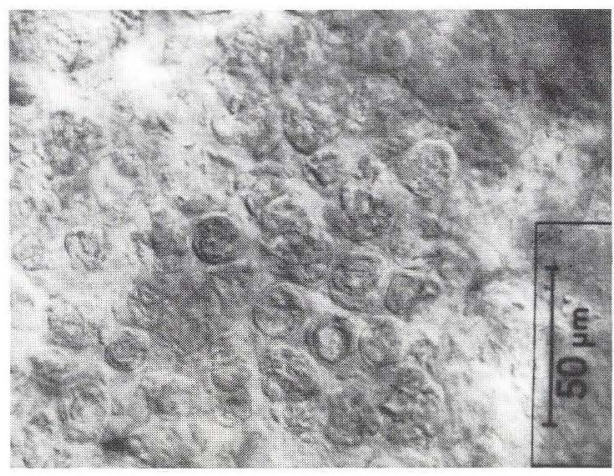

3

5

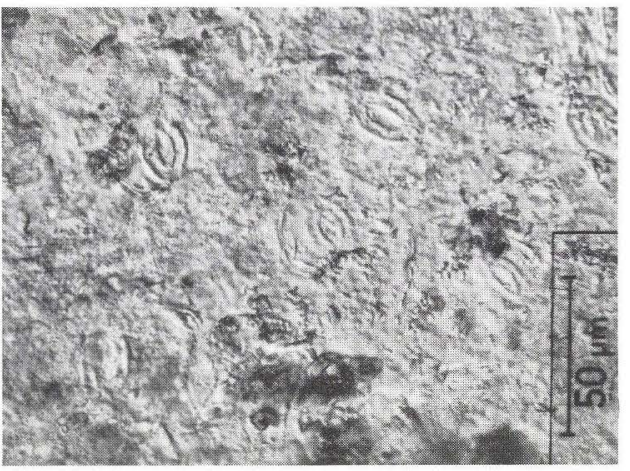

4

6
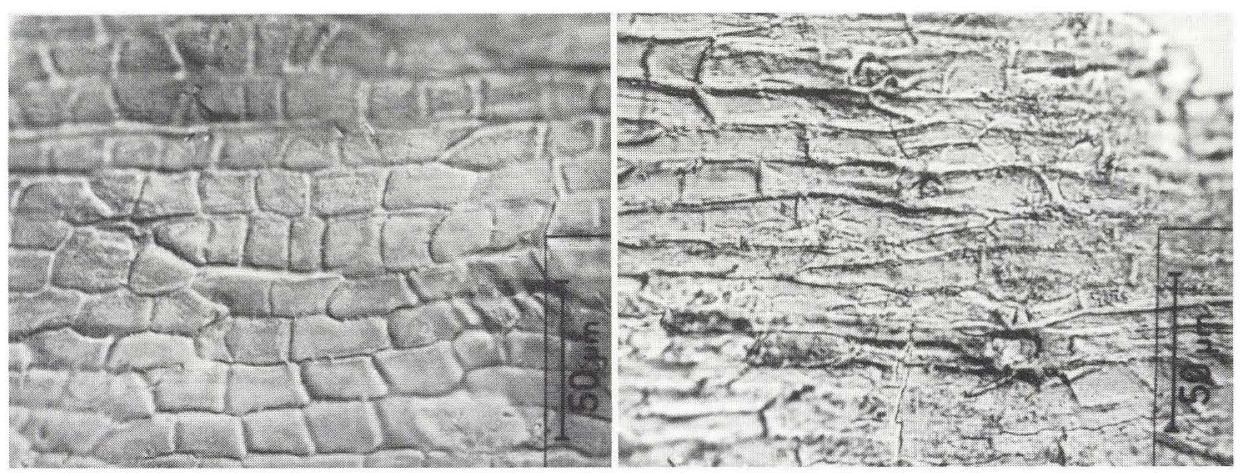
